\title{
Orality, Literacy, and the Early Notation of the Office Hymns
}

\author{
SUSAN BOYNTON
}

$\mathrm{I}$

$\mathrm{n}$ recent years, the relationship between orality and writing has become one of the most important areas in the study of the European Middle Ages. Historians have reached a broad consensus that oral and written traditions complemented one other to varying degrees from the ninth through the twelfth centuries. Written documents supported or reinforced ongoing oral traditions without replacing them, and oral communication played a central role even in highly literate communities. ${ }^{1}$ Much scholarship on orality and literacy emphasizes the increased importance of written and literate modes in the Carolingian period and the high Middle Ages; historians of Western music have focused most closely on the interplay of oral and written transmission in the ninth and tenth centuries. With regard to the earliest surviving examples of Western musical notation, the importance of orality may have been overstated. ${ }^{2}$ A more fruitful approach would interpret the function and context of

This article is dedicated to Michel Huglo. Earlier versions were presented at the Sixty-third Annual Meeting of the American Musicological Society, Phoenix, October-November 1997; the International Medieval Congress, University of Leeds; the University of Cincinnati CollegeConservatory of Music; and the Columbia University Music Department. The research was supported by a 1998 Summer Faculty Research Award from the University of Oregon and by an NEH Postdoctoral Rome Prize Fellowship at the American Academy in Rome in 1998-99. I am grateful to Isabelle Cochelin, Margot Fassler, Leeman Perkins, and Peter Jeffery for their comments, as well as to the anonymous readers for this Journal.

1. For a useful synthesis of previous scholarship, see Matthew Innes, "Memory, Orality and Literacy in Early Medieval Society," Past and Present 158 (1998): 3-36; and Marco Mostert, "New Approaches to Medieval Communication?" in New Approaches to Medieval Communication, ed. Marco Mostert (Turnhout: Brepols, 1999), 15-37 (see also the bibliography in New Approaches, 193-297). These studies build on Rosamond McKitterick, The Carolingians and the Written Word (Cambridge: Cambridge University Press, 1989); and Rosamond McKitterick, ed., The Uses of Literacy in Early Mediaeval Europe (Cambridge: Cambridge University Press, 1990).

2. As Sam Barrett noted in "Music and Writing: On the Compilation of Paris, Bibliothèque Nationale lat. 1154," "in stressing an oral context for the understanding of the earliest music notation, its most revolutionary aspect has been largely ignored: that is, its status as a written entity" (Early Music History 16 [1997]: 56). 
early musical notation as a manifestation of the interaction between orality and writing. ${ }^{3}$

This article takes the notation of the Office hymns in the eleventh century as the framework for a new investigation of orality and literacy in musical notation. Since their melodies were hardly ever written down before the year 1000 , the hymns offer an unprecedented opportunity to study the initial recording of an oral tradition in a period when the melodies of other chant genres had already been transmitted in writing for some time. The variety of ways in which entire hymn repertories and individual hymns were notated before 1100 signals both the increasing reliance on writing and the interaction between orality and literacy that characterize textual production in the eleventh century.

The first part of this essay outlines the historical and cultural context for the study of hymns as an oral tradition. The important place of the hymns in monastic education gave rise to commentary traditions that elucidate Guido of Arezzo's choice of "Ut queant laxis" as the basis for his new solmization system. Part 2 surveys the variety of approaches to hymn notation found in manuscripts through the early twelfth century, while part 3 places these notational phenomena in the broader context of two developments that are hallmarks of the period in which the manuscripts were created: monastic reform movements and increasing archival activity. The example of manuscript production at the central Italian abbey of Farfa serves to illustrate a proposed analogy between hymnaries and monastic customaries, both oral traditions that were written down and thus reinforced in the eleventh century, without entirely superseding their oral transmission. In the final section, I suggest that the increasing notation of hymns in the later eleventh and twelfth centuries, when several writers referred to confusion and disarray in the performance of hymns, signals a waning oral tradition.

\section{Why the Eleventh Century?}

Within the ever-changing symbiosis of orality and literacy during the Middle Ages, a particularly dramatic shift from reliance on oral traditions to a greater use of written documents is discernible in western Europe during the eleventh century. Historians have characterized this period as a crucial turning point between predominantly oral transmission and greater use of the written word, as well as a time of increased reification of memory through the renewal or

3. Clemens Kasper, "Text und Ton: Beobachtungen zur Bewertung des Verhältnisses von Musik, Text und Sprache bei der Verschriftlichung des Chorals," in Viva pox und ratio scripta: Mündliche und schriftliche Kommunikationsformen im Mönchtum des Mittelalters, ed. Clemens Kasper and Klaus Schreiner (Münster: LIT Verlag, 1997), 157-76; and James Grier, "Scribal Practices in the Aquitanian Versaria of the Twelfth Century: Towards a Typology of Error and Variant," this Journal 45 (1992): 373-427. 
revision of administrative and historiographic documents. ${ }^{4}$ Monastic scriptoria, in particular, produced increasing numbers of customaries, cartularies, and chronicles, all drawing upon both oral and written sources to some extent, and manifesting "the persistence of 'oral' ways of thought in a culture increasingly dominated by writing." In the eleventh century, the archival function of textual genres such as customaries, cartularies, and chronicles also manifested itself in the proliferation of notated liturgical manuscripts and in the expanding musical responsibilities of monastic librarians. As Margot Fassler has shown, it was in the eleventh century that the armarius (librarian), who was in charge of liturgical books, took over many of the functions of the cantor; this phenomenon seems linked to the increasing use of chant books. ${ }^{6}$ Monastic customaries of the eleventh and early twelfth centuries also reflect the expanding role of literacy in the musical and liturgical training of child oblates and adult novices. ${ }^{7}$ The exigencies of educating novices, and the aims of monastic reform, were catalysts for the production of monastic customaries during this period, showing the enhanced importance of written texts as well as the continued role of oral transmission. ${ }^{8}$ The interaction between writing and orality in monastic documents of the eleventh century manifests itself in the chant books, but has not attracted as much attention as comparable developments in the preceding and following centuries. This lacuna is as much a product of the historiography of musical notation and of Gregorian chant as it is of the nature of the documents themselves.

4. See Michael T. Clanchy, From Memory to Written Record: England, 1066-1307, 2d ed. (Oxford: Blackwell, 1993); Patrick Geary, Phantoms of Remembrance: Memory and Oblivion at the End of the First Millennium (Princeton: Princeton University Press, 1994); and Brian Stock, The Implications of Literacy: Written Language and Models of Interpretation in the Eleventh and Twelfth Centuries (Princeton: Princeton University Press, 1983).

5. I borrow this formulation from Mary Lynn Rampolla, “'A Pious Legend': St. Oswald and the Foundation of Worcester Cathedral Priory," in Oral Tradition in the Middle Ages, ed. W. F. H. Nicolaisen (Binghamton, N.Y.: Center for Medieval and Early Renaissance Studies, State University of New York at Binghamton, 1995), 210.

6. Margot Fassler, "The Office of the Cantor in Early Western Monastic Rules and Customaries: A Preliminary Investigation," Early Music History 5 (1985): 29-51, esp. 37-40.

7. Susan Boynton, "Training for the Liturgy as a Form of Monastic Education," in Medieval Monastic Education, ed. George Ferzoco and Carolyn Muessig (London and New York: Leicester University Press, 2000), 13-20; and idem, "The Liturgical Role of Children in Monastic Customaries from the Central Middle Ages," Studia liturgica 28 (1998): 194-209.

8. Fundamental studies of the Cluniac customaries include Kassius Hallinger, "Consuetudo: Begriff, Formen, Forschungsgeschichte, Inhalt," in Untersuchungen zu Kloster und Stift (Göttingen: Max-Plancks Institut, 1980), 140-66; and Dominique Iogna-Prat, "Coutumes et statuts clunisiens comme sources historiques (ca 990-1200)," Revue Mabillon 64 (1992): 23-48. For introductions to the genre, see Lin Donnat, "Les coutumiers monastiques: Une nouvelle entreprise et un territoire nouveau," Revue Mabillon 64 (1992): 5-21; and Eric Palazzo, A History of Liturgical Books from the Beginning to the Thirteenth Century, trans. Madeleine Beaumont (Collegeville, Minn.: The Liturgical Press, 1998), 213-20 (originally published as Histoire des livres liturgiques: Le Moyen Age, des origines au XIIIe siècle [Paris: Beauchesne, 1993], 221-27). 
Recently, the role of writing (or textuality, Schriftlichkeit) in the processes of unification and organization during the high Middle Ages has been a major focus of research, particularly by historians of the Münster school. The foundations were laid by Brian Stock's notion of the textual community, in which an essential component is a person using a central text to promote reform. ${ }^{9}$ Describing the role of literacy in social change in the high Middle Ages, Stock argues for a connection between reform and textual communities: "Sets of rules, that is, codes generated from written discourse, were employed not only to produce new behavioural patterns but to restructure existing ones. Literacy thereby intersected the progress of reform." 10 In the field of liturgical studies, Tom Elich has explored the role of written liturgical texts in the oral context of the medieval liturgy, arguing that the twelfth and thirteenth centuries saw the establishment of a new balance in favor of literacy in liturgical education and performance. ${ }^{11}$ Of course, evidence for the increasing importance of written chant transmission abounds in the twelfth and thirteenth centuries, with the production of numerous liturgical books, the formation of new religious orders striving for uniform liturgical practices (such as the Cistercians and Dominicans), and the consolidation of monastic congregations into more centralized orders (such as the Cluniacs). ${ }^{12}$ In addition to the diffusion of staff notation, the redaction of liturgical and other statutes for entire orders shows an increasing trend toward attempts at some kind of standardization or centralization, reflecting an already advanced and widespread use of writing. ${ }^{13}$

9. Stock, The Implications of Literacy, 90.

10. Ibid., 4.

11. See Tom Elich, "Using Liturgical Texts in the Middle Ages," in Fountain of Life: In Memory of Nils K. Rasmussen, O.P., ed. Gerard Austin (Washington, D.C.: Pastoral Press, 1991), 69-83; and idem, "Le contexte oral de la liturgie médiévale et le rôle du texte écrit," 3 vols. (Ph.D. diss., Institut Catholique, Paris, 1988). I am grateful to Pierre-Marie Gy, O.P., for advising me to read Elich's doctoral thesis, which is available for consultation at the Bibliothèque du Saulchoir, Paris.

12. On the role of writing in monastic reform and the new orders in the high and late Middle Ages, see particularly Florent Cygler, Gert Melville, and Jörg Oberste, “Aspekte zur Verbindung von Organisation und Schriftlichkeit im Ordenswesen: Ein Vergleich zwischen den Zisterziensern und Cluniazensern des 12./13. Jahrhunderts," in Viva vox, ed. Kasper and Schreiner, 205-80; Gert Melville, "Von der Regula regularum zur Stephansregel: Der normative Sonderweg der Grandmontenser bei der Auffächerung der vita religiosa im 12. Jahrhundert," in Vom Kloster zum Klosterverband: Das Werkzeug der Schriftlichkeit, ed. Hagen Keller and Franz Neiske (Munich: Wilhelm Fink, 1997), 342-63; and Klaus Schreiner, "Verschriftlichung als Faktor monastischer Reform: Funktionen von Schriftlichkeit im Ordenswesen des hohen und späten Mittelalters," in Pragmatische Schriftlichkeit im Mittelalter: Erscheinungsformen und Entwicklungsstufen, ed. Hagen Keller, Klaus Grubmüller, and Nikolaus Staubach (Munich: Wilhelm Fink, 1992), 37-75.

13. Felix Heinzer, "Kodifizierung und Vereinheitlichung liturgischer Traditionen: Historisches Phänomen und Interpretationsschlüssel handschriftlicher Überlieferung," in Musik in Mecklenburg: Beiträge eines Kolloquiums zur mecklenburgischen Musikgeschichte, ed. Karl Heller, Hartmut Möller, and Andreas Waczkat (Hildesheim: Georg Olms, 2000), 85-106. I am grateful to Dr. Heinzer for referring me to this article. For the transition at Cluny from customaries in the eleventh century to statutes in the twelfth, see Giles Constable, "Monastic Legislation at Cluny in the Eleventh and Twelfth Centuries," Proceedings of the Fourth International Congress of Medieval 
This situation contrasts with that in the eleventh century, when monastic customaries and hymnaries were based on a mixture of oral and written sources, while exhibiting an ongoing reliance on the oral tradition. Scholars have acknowledged the role of orality in monastic customaries of the eleventh century, but the hymnaries of the period have not been investigated from this perspective.

\section{The transmission and organization of hymn repertories}

While the elusive relationship between notation and performance is common to all music, the relative roles of oral and written transmission in Gregorian chant have received the lion's share of attention. Study of the "central question" of the origins of Gregorian chant has focused on the emergence of the tradition in the Frankish empire during the Carolingian period. Musical notation was still rare at this time; the earliest examples of notation that survive today date from the ninth century, and the earliest extant books containing the notated Mass Proper chants were copied around 900.14 The early transmission of the Gregorian Mass Propers has been the central focus of debate concerning when the melodies were first written down and how the written record relates to the music as it was performed. Because the earliest surviving notated graduals contain a relatively stable melodic tradition, Kenneth Levy has argued that our oldest notated chant books are the descendants of a long line of lost manuscripts, implying that the role of written transmission is predominant in the earliest surviving witnesses to the melodies. ${ }^{15} \mathrm{~A}$ different view, held by Leo Treitler, among others, maintains that orality shaped the melodies and the manuscripts, and sees performance and writing of music as structured recreations guided by a system of formal rules. ${ }^{16}$ Peter Jeffery has stated that an "oral/written continuum" describes chant transmission more effectively than

Canon Law (Vatican City: Biblioteca Apostolica Vaticana, 1976), 151-61 (reprinted in his Cluniac Studies [London: Variorum Reprints, 1980]); and Gert Melville, "From the Cluny of 'Consuetudines' to the Cluny of 'Statuta': A Changing from the Past to the Future," in From Dead of Night to End of Day: The Medieval Customs of Cluny, ed. Susan Boynton and Isabelle Cochelin (Turnhout: Brepols, forthcoming in 2004).

14. Hartmut Möller describes what may be the earliest extant notated chant, in "Die Prosula 'Psalle modulamina' (Mü 9543) und ihre musikhistorische Bedeutung," in La tradizione dei tropi liturgici, ed. Claudio Leonardi and Enrico Menestò (Spoleto: Centro Italiano di Studi sull'Alto Medioevo, 1993), 279-301. For a list of the earliest notated graduals, see Kenneth Levy, "Charlemagne's Archetype of Gregorian Chant," this Journal 40 (1987): 5.

15. Levy has expounded this view most recently in his Gregorian Chant and the Carolingians (Princeton: Princeton University Press, 1998) and "From Aural to Notational: The Gregorian Antiphonale Missarum," Études grégoriennes 28 (2000): 5-19.

16. Among Treitler's many publications on this subject, see particularly "Oral, Written, and Literate Process in the Transmission of Medieval Music," Speculum 56 (1981): 471-91; "Reading and Singing: On the Genesis of Occidental Music-Writing," Early Music History 4 (1984): 135-208; and "The 'Unwritten' and 'Written Transmission' of Medieval Chant and the Start-up of Musical Notation," Journal of Musicology 10 (1992): 131-91. 
a strict polarity, given the symbiosis of orality and literacy evident in other aspects of medieval culture. ${ }^{17}$

The study of oral and written transmission in chant has focused primarily on the Proper chants of the mass, so examining a different genre in a later time period can lead to fresh insights. ${ }^{18}$ As Richard Crocker has noted, it is difficult to demonstrate the precise role of orality in music "in a context marked by the absence of written musical record." 19 We stand to learn a great deal about the oral-written continuum from the recording of an oral repertory at a time when notated books were increasingly numerous, and many chant melodies had long been written down. The Office hymns are a particularly promising repertory for such an investigation because their melodies remained an oral tradition longer than those of other chant genres. The performance of hymns was introduced at Milan by Ambrose in the fourth century, and their place in the monastic Office was described in the sixth-century rules of Arles and of Benedict. But only beginning in the mid-eleventh century, over a hundred years after the production of the earliest notated graduals, were hymn melodies written down to any great extent. Hymn texts, however, are attested by an abundant manuscript tradition that began hundreds of years before the earliest notated examples. Hymnaries survive from as early as the seventh and eighth centuries; there are twenty-five hymn manuscripts from the eighth and ninth centuries alone. ${ }^{20}$

Very few hymnaries from before the eleventh century contain notation, and even in the eleventh century, the notation of hymns remained the exception rather than the rule. The format of most hymn collections before 1100 made no provision for notation at all. Scribes usually did not make allowances for neumes, but notation was sometimes added after the text was written. In many breviaries, notationless hymns are juxtaposed with notated antiphons and responsories on the same page. ${ }^{21}$ Hymn texts were often written out in

17. Peter Jeffery, Re-envisioning Past Musical Cultures: Ethnomusicology in the Study of Gregorian Chant (Chicago and London: University of Chicago Press, 1992), 62-70.

18. In the case of tropes, this has been demonstrated in Alejandro Enrique Planchart, "On the Nature of Transmission and Change in Trope Repertories," this Journal 41 (1988): 215-49; and Treitler, "Oral, Written, and Literate Process."

19. Richard Crocker, "Gregorian Studies in the Twenty-first Century," Plainsong and Medieval Music 4 (1995): 63.

20. On the earliest hymnaries, see Helmut Gneuss, Hymnar und Hymnen im englischen Mittelalter: Studien zur Überlieferung, Glossierung und Übersetzung lateinischer Hymnen in England (Tübingen: Max Niemeyer, 1968), 10-54; idem, “Zur Geschichte des Hymnars," Mittellateinisches Jabrbuch 35 (2000): 227-47; and Marie-Hélène Jullien, "Les sources de la tradition ancienne des quatorze Hymnes attribuées à saint Ambroise de Milan," Revue d'bistoire des textes 19 (1989): 83-91.

21. Examples include Berlin, Staatsbibliothek Preußischer Kulturbesitz, MS Theol. lat. $4^{0}$ 377; London, British Library, MS Add. 30848; Montecassino, Archivio dell'Abbazia, MS 420; Oxford, Bodleian Library, MS Misc. lit. 366; Rome, Biblioteca Casanatense, MS 1907; Vatican City, Biblioteca Apostolica Vaticana (hereafter BAV), MS Vat. lat. 7018; Paris, Bibliothèque Nationale de France (hereafter BNF), MS lat. 12601; and Paris, BNF, MS lat. 17791. 
full, frequently in a format resembling that of Latin prose, without prominent demarcation of verses or strophes. In breviaries that generally differentiate between sung and read texts by presenting them in scripts of different sizes, the hymns are often copied in the larger script used for the prayers and lessons, rather than in the smaller one of the antiphons and responsories. The reasons for this distinction are unclear. Scribes would have known that the hymns were sung, and they could have saved space by copying hymn texts in the smaller script employed for other chants, which has the added advantage of leaving sufficient space for notation to be added later. Hymn texts in the larger script appear awkward to notate (as will be seen in several examples discussed below). The text script and prose format employed for the hymns seems to show that they were not supposed to be notated, suggesting that the oral tradition of the hymns continued even as other genres were increasingly notated.

The graphic distinction between hymns as "texts" and other genres as "chants" was not always systematic, however. In an eleventh-century breviary from Brescia (Oxford, Bodleian Library, MS Misc. lit. 366), the hymns are written in prose format, in the same module as the prayers and readings, and most lack notation. Only the three hymns with notation were copied in the same size of script as the chant texts. ${ }^{22}$ The scribe may have used the chanttext script only for those hymns that were supposed to be notated, but two hymn texts in this script were in fact never notated. ${ }^{23}$

Usually only a fraction of the hymn repertory in a given manuscript is notated, and only two hymnaries from before 1100 contain notation for all their texts: Huesca, Archivo de la Catedral, MS 1 and Verona, Biblioteca Capitolare, MS CIX (102). ${ }^{24}$ These late eleventh-century hymnaries offer rare insight into the organization of entire hymn repertories, in which many different texts could be sung to the same melody. Often in medieval hymnaries, an individual melody is indicated for use with several hymn texts that share a liturgical position or meter. For example, an individual melody might be associated with Matins by being sung with four or five different Matins texts, with virgin martyrs because it was sung with texts for feasts of several different saints in that category, or with several different texts in iambic or sapphic meter. A manuscript may indicate a single melody to be sung to the hymns of different

22. The three notated hymns are "Conditor alme siderum" and "Nocte surgentes" on folio $39 \mathrm{r}$ and "Ad cenam agni" on folio $150 \mathrm{v}$. It is not clear why these three hymns were selected for notation, since only the third exhibits variants between the strophes, and all three melodies were among those best known. If the manuscript follows the system of implicit organization discussed below, the melodies would be notated with only one text but sung with other texts as well.

23. "A solis ortus cardine" and "Hostis Herodes impie." These two texts would presumably be sung to the same melody, since the latter is a divisio or subdivision of the former.

24. The melodies in the Verona manuscript have been edited by Bruno Stäblein in Hymnen: Die mittelalterlichen Hymnenmelodien des Abendlandes (Kassel and Basel: Bärenreiter, 1956), 358-405. The Huesca manuscript was published in facsimile in volume 1 of Hymnarium Oscense (S. XI), ed. Antonio Durán, Ramón Moragas, and Juan Villarreal (Zaragoza: Institución Fernando el Católico, 1987). The melodies are transcribed in Hymnarium Oscense 2:101-23. 
canonical hours on the same day, or for several texts sung at the same hour on different days, though this approach is not always consistent. A melody may not have the same associations in two different hymnaries. From each notated manuscript can be extrapolated, or at least hypothesized, principles by which the melodies are paired with texts within that particular book and local repertory.

Notated hymnaries from the eleventh and twelfth centuries employ such systematic melody-text pairing to varying degrees. Some manuscripts are organized primarily around the liturgical function of texts, while others mix metrical with liturgical groupings. A given manuscript may use a single melody for several different canonical hours or for several texts sung at the same hour, but may not assign a melody to feasts that are related thematically. Some hymnaries, such as Verona CIX (102), assign one melody to all hymns for ferial Matins, another to those for ferial Lauds, and a third to those for ferial Vespers. The Huesca hymnary employs both this grouping by liturgical function and similar groupings of iambic and sapphic texts that are not liturgically related to one another. ${ }^{25}$

Repertorial organization like that extrapolated from the Verona and Huesca hymnaries would, at least in theory, make it unnecessary to notate a melody more than once within a manuscript. If a hymn text was sung to a melody that appears in the same manuscript with another text, it would have been redundant to notate each separate use of the melody. As Ruth Steiner has pointed out, evidence of a coherent system in a fully notated manuscript enables one to extrapolate that such a system is at work in another manuscript with only sporadic notation. ${ }^{26} \mathrm{~A}$ hymnary with sporadic notation may employ a system of text-melody pairing of the kind that is made clear in the fully notated hymnaries; thus if a melody is notated only once, one can assume that the hymns for the same hour would be sung to the same melody. For example, in Vatican City, BAV, MS Reg. lat. 338, an eleventh-century manuscript from England or northern France, ${ }^{27}$ only the first three hymns- "Primo dierum omnium," "Aeterne rerum conditor," and "Nocte surgentes"-are notated. In most fully notated hymnaries, each of these texts is paired with a different melody, and each of the three melodies is usually associated with several other texts in the manuscript. A trained singer would have internalized the principles by which to associate these melodies with other texts. The adiastematic

25. For further discussion of these two manuscripts and tables showing the organization of their melodies, see Susan Boynton, "Glossed Hymns in Eleventh-Century Continental Hymnaries" (Ph.D. diss., Brandeis University, 1997), 57-61, 86-95.

26. Ruth Steiner, "Hymn," sec. II, "Monophonic Latin," in The New Grove Dictionary of Music and Musicians (1980), 8:839.

27. On this manuscript, see Jullien, "Les sources," 109-10; André Wilmart, Codices reginenses latini, vol. 2, Codices 251-500 (Vatican City: Biblioteca Apostolica Vaticana, 1945), 263. On the neumes, see Henry Marriott Bannister, Monumenti vaticani di paleografia musicale latina (Leipzig: Harrassowitz, 1913), 75, and table 4lb. 
neumes of the Vatican manuscript provide information on melodic contour and nuance, as well as indicate variants between strophes in both "Primo dierum omnium" and "Aeterne rerum conditor" (of which the first two strophes are notated). The oral tradition would complete the information in the manuscript.

If the state of the repertories in the earlier manuscripts reflects the general profile of the oral tradition, it seems that a relatively small corpus of melodies sufficed for the performance of a great many texts. In the twelfth century, hymn melodies were more frequently notated, and a greater variety of melody-text combinations appear. Twelfth-century manuscripts from Nevers and Gaeta contain a greater number of distinct melody-text pairs than eleventh-century hymnaries, generally pairing fewer melodies with multiple texts, and even including multiple melodies for some texts. Nevertheless, even in these hymnaries some melodies are paired with multiple texts. ${ }^{28} \mathrm{~A}$ few twelfth- and thirteenth-century manuscripts exhibit an almost one-to-one correspondence between melodies and texts. In both the twelfth-century hymnary Einsiedeln, Stiftsbibliothek, MS 366 and the thirteenth-century Worcester hymnary (Worcester, Cathedral Library, MS F.160), very few texts share the same melody. ${ }^{29}$ There is a striking difference between the systems of melody-text pairing in eleventh-century manuscripts and those in thirteenthcentury ones. The increase over time in the number of different melodies in hymnaries may be a sign of the growing role played by written sources in the creation and organization of the repertories.

Literate modes of transmission may also have inspired some experimentation with the notation of hymns, such as the apparently superfluous addition of tonary letters in the margins of the Einsiedeln hymnary, a unique use of modal signs in a hymnary, which could have functioned as a mnemonic device. ${ }^{30}$ The Einsiedeln hymnary is also unusual in that it includes only the first strophe of each hymn text, suggesting that the compiler was more interested in exploring methods for the recording of melodies than in copying a complete hymn repertory. The eleventh-century hymnary from Kempten (Zurich, Zentralbibliothek, MS Rheinau 83) contains both letter notation and neumes, and the annotation of the manuscript by a variety of users suggests an ongoing negotiation between oral and written traditions (see the discussion of this manuscript below). ${ }^{31}$ Such intriguing adaptations of notational conventions

28. Paris, BNF, MS n.a.l. 1235 and Rome, Biblioteca Casanatense, MS 1574. For tables showing the melodic organization of these manuscripts, see Boynton, "Glossed Hymns," 96-101.

29. For editions of the melodies in the Einsiedeln and Worcester manuscripts, see Stäblein, ed., Hymnen, 262-301 and 170-204.

30. Facsimile edition in Basilius Ebel, Das älteste alemannische Hymnar mit Noten, Kodex 366 Einsiedeln (XII. Jabrhundert) (Einsiedeln: Benziger, 1930). For commentary on the tonary letters, see pp. 30-44.

31. For the most recent description and bibliography, see Jullien, "Les sources," 104-5. On the notation, see below. 
may reflect attempts to render through written signs some elusive aspects of an ongoing oral tradition. The sporadic notation of many eleventh-century manuscripts suggests habits of recalling melodies or parts of melodies rather than writing them all down.

The predominantly oral tradition of the hymn melodies that persisted in the eleventh century may have encouraged the maintenance of more "efficient" ways of organizing hymn repertories that employed relatively few melodies, making memorization easier. In this way, the structure of early hymn repertories resembles an art of memory, insofar as it can be extrapolated from the hymnaries of the eleventh and twelfth centuries. ${ }^{32}$ While students of medieval memory systems focus primarily on the memorization of texts, which often employed visual imagery, ${ }^{33}$ several other types of memory are also relevant to the notation and transmission of the hymn repertory. These include liturgical and monumental commemoration, the preservation of documentation that Patrick Geary has called "archival memory," and narrative forms of collective memory. ${ }^{34}$ Singing a hymn melody to several different texts linked the texts in the minds of singers, probably helping them to memorize the dozens of hymn texts in medieval repertories. The notion that melodies can help singers remember texts in an oral tradition is supported by recent

32. My understanding of the role of memory in hymn repertories is inspired by Margot Fassler's work on the sequence repertory at St. Victor in Paris as an art of memory. See her Gothic Song: Victorine Sequences and Augustinian Reform in Twelfth-Century Paris (Cambridge: Cambridge University Press, 1993), esp. 290-96, 316-17.

33. On memory in the Middle Ages, see particularly Mary Carruthers, The Book of Memory: A Study of Memory in Medieval Culture (Cambridge: Cambridge University Press, 1990); idem, The Craft of Thought: Meditation, Rhetoric, and the Making of Images, 400-1200 (Cambridge: Cambridge University Press, 1998); and Frances Yates, The Art of Memory (Chicago: University of Chicago Press, 1966), 50-104. The study of medieval memory processes by nonmusicologists has paid little attention to music, focusing on procedures associated with the memorization of texts alone. Some recent studies by musicologists that address aspects of medieval memory are Anna Maria Busse Berger, "Mnemotechnics and Notre Dame Polyphony," Journal of Musicology 14 (1996): 263-98; Jeffery, Re-envisioning Past Musical Cultures; several studies by Kenneth Levy grouped in Gregorian Chant and the Carolingians; Kay Kaufman Shelemay, Peter Jeffery, and Ingrid Monson, "Oral and Written Transmission in Ethiopian Christian Chant," Early Music History 12 (1993): 55-117; and Treitler, “'Unwritten' and 'Written Transmission,'” 145-49.

34. On the medieval liturgy as the enactment of memory through ritual commemoration, see particularly Karl Schmid and Joachim Wollasch, eds., Memoria: Der geschichtliche Zeugniswert des liturgischen Gedenkens im Mittelalter (Munich: Wilhelm Fink, 1984); and Megan McLaughlin, Consorting with Saints: Prayer for the Dead in Early Medieval France (Ithaca, N.Y., and London: Cornell University Press, 1994). Recent important studies of monumental memory include Elizabeth Valdez del Alamo, ed., with Carol Pendergast, Memory and the Medieval Tomb (Aldershot: Ashgate, 2000); and Amy Remensnyder, "Legendary Treasure at Conques: Reliquaries and Imaginative Memory," Speculum 71 (1996): 885-906. For Geary's definition of "archival memory," see Phantoms of Remembrance, 81-114; on collective memory, see particularly Amy Remensnyder, Remembering Kings Past: Monastic Foundation Legends in Medieval Southern France (Ithaca, N.Y., and London: Cornell University Press, 1995); and James Fentress and Chris Wickham, Social Memory (Oxford: Blackwell, 1992). 
research in cognitive psychology. ${ }^{35}$ Of course, such cognitive research reaffirms the well-known insights of musicologists (such as Levy, Treitler, and Theodore Karp) who have studied the role of memory in the transmission of chant.

Medieval music theorists generally did not describe systems for the organization of hymn repertories, presumably because they were internalized as part of the general body of knowledge passed on to singers orally. A rare and rather oblique reference occurs in a late eleventh-century customary written for the abbey of Cluny by the monk Bernard, who remarks that on the feast of the Trinity, the hymn "Tu trinitatis unitas" was sung at Cluny "in $\mathrm{t}[\mathrm{h}]$ ono de Ihesu nostra redemptio" ("to the melody of 'Iesu nostra redemptio' "). ${ }^{36}$ In the context of oral transmission, the textual incipit of a hymn could recall its melodies, creating a network of mental associations among liturgical occasions. ${ }^{37}$

The differences in notation between earlier and later hymn sources described here suggest that the melodies were primarily an oral tradition until the twelfth century. The notation of hymns thus provides an unparalleled opportunity to study the recording of an oral tradition-and thereby to observe the interaction of orality and literacy in musical notation.

\section{The hymns and monastic education}

Hymns can be studied as an oral tradition not only musically, but also through their role in monastic education. ${ }^{38}$ Unlike responsorial chants, hymns were

35. David Rubin, Memory in Oral Traditions: The Cognitive Psychology of Epic, Ballads, and Counting-out Rhymes (New York: Oxford University Press, 1995), esp. 109-12, 144-46, 257307; and Wanda T. Wallace, "Memory for Music: Effect of Melody on Recall of Text," Journal of Experimental Psychology: Learning, Memory, and Cognition 20 (1994): 1471-85. See also Susan Boynton, review of Kenneth Levy's Gregorian Chant and the Carolingians and Theodore Karp's Aspects of Orality and Formularity in Gregorian Chant, this Journal 53 (2000): 141-52. For a useful overview of several pertinent issues in cognition, see Bob Snyder, Music and Memory: An Introduction (Cambridge, Mass., and London: MIT Press, 2000).

36. Bernard, "Ordo cluniacensis," in Vetus disciplina monastica, ed. Marquard Herrgott (Paris: Osmont, 1726), 334; and Paris, BNF, MS lat. 13875, fol. 15r. All translations are my own unless otherwise indicated. Isabelle Cochelin and I are preparing a diplomatic edition of Bernard's text from Paris, BNF, MS lat. 13875 with English and French translations.

37. The recall effected by incipits may explain the cases in which only the first few words of the text are notated, as in Rouen, Bibliothèque Municipale, MS 243, a notated breviary from Marmoutier. Apparently the format of the hymns in the manuscript was not designed for notation at all, and the main notator neumed incipits almost exclusively.

38. The evidence suggests that, from some point in the ninth century until the early twelfth, the hymns were sung primarily in the monastic Office. Hymns were performed in the Milanese and Old Hispanic cathedral Offices in this period, but usually are transmitted in monastic manuscripts; see Jullien, "Les sources." The question of why this should be so deserves more attention. The Rule of Benedict prescribes hymns in the Divine Office; the association of hymns with monastic liturgy in the central Middle Ages could have resulted from the increased diffusion and heightened observance of the Benedictine Rule in the ninth through eleventh centuries. 
memorized by all monks as child oblates or as novices. ${ }^{39}$ Moreover, the hymns were part of the literary tradition of Christian Latin poetry; they are often found in nonliturgical poetic anthologies, and many hymns that entered the liturgy in the Carolingian period were actually excerpts from the Christian Latin classics, such as the Carmen paschale of Sedulius and the Liber cathemerinon of Prudentius. Since the Office hymns were the first poetic texts that students encountered in their grammatical and literary studies, they provided a foundation in the vocabulary, syntax, and metrics of Latin poetry.

Along with the psalms, hymns provided the material of elementary monastic education, and several medieval hymnaries were annotated with Latin glosses. ${ }^{40}$ Early hymn glosses constitute the most extensive body of liturgical commentary on a chant genre from the period before 1100. Like the psalms, the hymns functioned both as liturgical chants and as theological texts, with a didactic tradition going back to their congregational use by Ambrose of Milan in the fourth century. ${ }^{41}$ Grammatical teaching based on the hymns began with Augustine's instructive analysis of "Deus creator omnium" in the Confessions and in book 6 of De musica. The glosses found in eleventh-century manuscripts are the predecessors to the hymn commentaries of the later Middle Ages, which were transmitted in collections of grammatical texts and were printed as schoolbooks in the fifteenth and sixteenth centuries. ${ }^{42}$ The idea of the hymnary as a book for reading appears already in early medieval hymnaries with vernacular interlinear glosses. ${ }^{43}$

39. The hymns were part of the basic liturgical curriculum as early as the Murbach Statutes of 816, preliminary acts to the synod of Aachen that described the school reforms of Abbot Atto of Reichenau. The text is edited as "Actuum praeliminarium synodi primae aquisgranensis commentationes sive Statuta Murbacensia (816)," in Consuetudines saeculi octavi et noni, ed. Josef Semmler (Siegburg: Franz Schmitt, 1963), 442.

40. On the typology of these glosses, see Susan Boynton, "Glosses on the Office Hymns in Eleventh-Century Continental Hymnaries," The Journal of Medieval Latin 11 (2001): 1-26. Not all hymn glosses were in Latin, however; several recensions survive of glosses in Germanic and Celtic languages. On Anglo-Saxon hymn glosses, see Gneuss, Hymnar und Hymnen; and Inge Milfull, The Hymns of the Anglo-Saxon Church (Cambridge: Cambridge University Press, 1996). On Irish hymn glosses, see J. H. Bernard and R. Atkinson, eds., The Irish Liber Hymnorum (London: Henry Bradshaw Society, 1898). And on Old High German glosses, see Eduard Sievers, ed., Die Murbacher Hymnen (Halle: Verlag der Buchhandlung des Waisenhauses, 1874).

41. For a survey of the role of hymns in education beginning with Augustine of Hippo, see Boynton, "Glossed Hymns," 173-231.

42. On late medieval hymn glosses, see Judson Allen, "Commentary as Criticism: The Late Medieval Accessus," in Acta Conventus Neo-Latini Lovaniensis: Proceedings of the First International Congress of Neo-Latin Studies, Louvain, 23-28 August 1971, ed. Jozef Ijsewijn and Eckhard Keßler (Leuven: Leuven University Press; Munich: Wilhelm Fink, 1973), 29-48.

43. The perception of the hymnary as a literary text became more common in the high Middle Ages. One striking example is a twelfth-century glossed psalter from Jumièges (Rouen, Bibliothèque Municipale, MS 57), in which the hymnary lacks notation altogether and is preceded by a long prologue. For a description of this manuscript, see Victor Leroquais, Les psautiers manuscrits latins des bibliothèques publiques de France (Mâcon: Protat, 1940-41), 2:185. On manuscripts reflecting medieval habits of reading texts through their glosses, see particularly Martin 
The presence of glosses in a manuscript did not contradict the musical character of the hymns, however. Glosses appear not only in books for reading but also in notated chant books, sometimes alongside notation on the same page (as in Figure 4 below), and sometimes even combined with notation in the same hymn. It seems likely that these glosses were added to the books by those who taught the hymns to singers.

The hymns' manifold functions are best illustrated by "Ut queant laxis," an eighth-century hymn for John the Baptist attributed to Paul the Deacon. While "Ut queant laxis" is one of the best-known works from the Middle Ages, the context of its lasting significance has never been fully understood. Guido of Arezzo must have either invented a new melody for "Ut queant laxis" or reworked an existing one, since the melody transmitted in several sources of his Epistola de ignoto cantu is not found in any liturgical manuscripts before the end of the twelfth century. ${ }^{44}$ His choice of the first strophe of the hymn was therefore motivated by the text. ${ }^{45}$ In addition to the strophe's obvious references to singing, scholars have proposed other textual reasons for its use in the solmization system, including interpretations of the solmization syllables as a mystical cryptogram. ${ }^{46}$ Glosses on "Ut queant laxis" in hymnaries suggest yet another explanation: Guido chose the text from the monastic tradition of grammatical teaching of which it was a part. Eleventh-century hymnaries from northern and southern French monasteries with extensive glosses on "Ut queant laxis," as well as some from central Italy, attest to a widespread pedagogical interest in the language and content of the text prior to Guido's Epistola. ${ }^{47}$

Irvine, The Making of Textual Culture: “Grammatica” and Literary Theory, 350-1100 (Cambridge: Cambridge University Press, 1994); and Suzanne Reynolds, Medieval Reading: Grammar, Rhetoric and the Classical Text (Cambridge: Cambridge University Press, 1996).

44. See Jacques Chailley, "Ut queant laxis' et les origines de la gamme," Acta musicologica 56 (1984): 48-69; Denis Harbinson, "The Hymn 'Ut queant laxis,'” Music and Letters 52 (1971): 55-58; and Claude Palisca, "Guido of Arezzo," in The New Grove Dictionary of Music and Musicians (1980), 7:805. Joseph Smits van Waesberghe, however, maintains that Guido did not compose the melody himself (De musico-paedagogico et theoretico Guidone Aretino eiusque vita et moribus [Florence: Olschki, 1953], 99); another proponent of this view is Ephrem Omlin ("Guido von Arezzo und der Johanneshymnus Ut queant laxis," in J. B. Hilber: Festgabe zu seinem 60. Geburtstage [Altdorf: Schweizer Kirchenmusikverlag, 1951], 46-54).

45. I disagree with Carl-Allan Moberg, who argued that Guido chose "Ut queant laxis" for its melody and then reworked it using the improvisation technique applied to "Iam lucis orto sidere" ("Die Musik in Guido von Arezzos Solmisationshymne," Archiv für Musikwissenschaft 16 [1959]: 186-206).

46. Jacques Chailley and Jacques Viret, "Le symbolisme de la gamme," La revue musicale 408-9 (1988): 7-150; and Jacques Viret, "Un cryptogramme carolingien du Christ-Soleil," in Le soleil, la lune et les étoiles au moyen âge (Aix-en-Provence: Université de Provence; Marseille: Laffitte, 1983), 421-35.

47. Commentaries on "Ut queant laxis" are not limited to glosses in liturgical books; the hymn was the sole subject of a lengthy thirteenth-century grammatical commentary. For a preliminary report on the text, see Peter Stotz, "Poesie auf dem Exerzierfeld: Über einen sprachlichen 
The glosses on "Ut queant laxis" illustrate the commonplace that monastic education combined learning the monastic life with the study of grammar, which was taught primarily through the liturgy. ${ }^{48}$ Given the degree of attention focused on "Ut queant laxis" in the commentary tradition, it comes as no surprise that the hymn provides the ideal text for teaching the central themes of monasticism, by according particular emphasis to the Baptist's asceticism, his life in the desert, and his virginity. Beginning in late antiquity, John the Baptist was widely associated with desert monasticism. ${ }^{49}$ The ninth strophe of "Ut queant laxis" refers to John as "inhabitant of the desert of the prophets," glossed in Paris, BNF, MS lat. 11550 with the comment: "He first perfected the eremetical and monastic life," which expresses the common notion that the Baptist founded the monastic tradition..$^{50}$ Isidore of Seville's De ecclesiasticis officiis identifies John as the founder of monasticism, and the first desert fathers as his successors. ${ }^{51}$ Isidore also referred to John in his Etymologiae, distinguishing anchorites, who imitate Elijah and John, from cenobites, who imitate the Apostles. ${ }^{52}$ The pairing of Elijah and John the Baptist as monastic forerunners was a recurrent topos in late antiquity and the Middle Ages, as in

Kommentar zu dem Hymnus Ut queant laxis auf Johannes den Täufer," in Italica-RaeticaGallica: Studia linguarum litterarum artiumque in bonorem Ricarda Liver, ed. Peter Wunderli, Iwar Werlen, and Matthias Grünert (Tübingen and Basel: A. Francke, 2001), 637-53. I am grateful to the author for sending me this paper before its publication, as well as his unpublished transcription of the commentary.

48. As formulated by Jean Leclercq, monastic education was simply the process of learning to be a monk: see his "Les études dans les monastères du Xe au XIIe siècle," in Los monjes y los estudios: IV Semana de estudios monasticos (Poblet: Abadia de Poblet, 1963), 115-17; idem, "The Monastic Tradition of Culture and Studies," American Benedictine Review 11 (1960): 99-131; and idem, The Love of Learning and the Desire for God: A Study of Monastic Culture, trans. Catharine Misrahi, 3d ed. (New York: Fordham University Press, 1982). For a bibliography on education in the monastic and mendicant orders, see Ferzoco and Muessig, eds., Medieval Monastic Education, which supplements and updates La scuola nell'occidente latino dell'alto medioevo (Spoleto: Centro Italiano di Studi sull'Alto Medioevo, 1972).

49. On the interpretation of John the Baptist in Christian antiquity, see Carl Kazmierski, John the Baptist: Prophet and Evangelist (Collegeville, Minn.: Liturgical Press, 1996).

50. "Ipse heremiticam uitam et monasticam prius excoluit" (Paris, BNF, MS lat. 11550, fol. 272v). On this tradition of interpretation, see Josef Ernst, Jobannes der Täufer: InterpretationGeschichte-Wirkungsgeschichte (Berlin and New York: Walter de Gruyter, 1989), 242-44 (I am grateful to Otfried Lieberknecht for this reference); and Gregorio Penco, "S. Giovanni Battista nel ricordo del monachesimo medievale," Studia monastica 3 (1961): 7-32.

51. Isidore of Seville, De ecclesiasticis officiis, ed. Christopher Lawson (Turnhout: Brepols, 1989), 74 (II.16).

52. Isidori Hispalensis episcopi Etymologiarum siue originum libri $X X$, ed. W. M. Lindsay (Oxford: Clarendon Press, 1911), VII.xiii.3-4. Isidore's distinction may derive from Jerome's Epistula 22, which names John as the most illustrious of early hermits: see Jerome, Sancti Eusebii Hieronymi Epistulae, ed. Isidore Hilberg (Vienna: Tempsky; Leipzig: Freytag, 1910), 200. 
the influential Vita of Abbot Maiolus of Cluny written by his successor Odilo. ${ }^{53}$

The tenth strophe of "Ut queant laxis" further emphasizes John's representation of monastic ideals, this time through reference to his virginity: "Thirty crowns crown some; augmented again by two, it crowns certain others; you, holy one, are crowned three times a hundredfold with accumulated fruit." 54 The marginal gloss on this strophe in three eleventh-century northern French manuscripts elucidates the scriptural reference:

This is taken from the Gospel, where it is said of the seed thrown on the ground, that one bore thirtyfold fruit, another sixtyfold, and another hundredfold fruit. And the sense is: Crowns, augmented threefold by increments of ten, that is multiplied by thirtyfold fruit, crown some- that is, reward virtuous spouses-since virtuous spouses ascend to the thirtyfold fruit. Doubled crowns, that is, sixtyfold fruit which pertains especially to celibates, crown certain other ones-that is, celibates and prelates, who live in chastity and serve with good works. Increased, they adorn you, O holy John, with the hundredfold fruit, since virgins receive the palm of the hundredth fruit. ${ }^{55}$

The strophe refers to the parable of the sower and the seeds in the Gospels, in which some seeds fall on the path and are eaten by birds, others fall on rocky ground and are dried out by the sun, and still others fall on good soil and produce grain, either a hundredfold, sixtyfold, or thirtyfold. In the Gospel of Matthew, Jesus compares the seeds that produce grain to those who hear and understand the Word.56 One patristic tradition of exegesis on this parable matches the hundredfold crop with martyrs, the sixtyfold with virgins, and the thirtyfold with abstinent spouses or widows. Jerome, like many other patristic

53. "Deinde coepit monasticus ordo pullulare, et, ut verius dicamus, reviviscere; quem a beato Helia et Joanne Baptista novimus processisse" ("Then the monastic discipline began to spread, and, so that we speak more truly, to come to life again, [a discipline] which we know originated with Elijah and John the Baptist") (Odilo of Cluny, De vita beati Maioli abbatis libellus, in Patrologiae cursus completus: Series latina, ed. J.-P. Migne, vol. 142 [Paris: Migne, 1853], col. 945). I am grateful to Isabelle Cochelin for this reference. Peter Jeffery pointed out in a personal communication that the identification of John the Baptist with Elijah originated in Matthew 11:14, Matthew 17:12, and Luke 1:17.

54. "Serta ter denis alios coronant; aucta crementis duplicata quosdam; trina centeno cumulata fructu te sacer ornant."

55. "Hoc ex euangelio sumptum est, ubi deiactato in terram semine dicitur, quod aliud tricesimum, aliud sexagesimum, atque aliud centesimum fructum attulit. Est itaque sensus: Serta, id est corone, ter denis crementis aucta, id est tricesimo fructu multiplicata, alios coronant, id est bonos coniugatos remunerant, quia boni coniugati ad tricesimum fructum ascendunt. Quosdam, id est alios scilicet continentes et prelatos, qui in castitate uiuunt et bonis operibus inseruiunt coronant duplicata serta, id est sexagesimus fructus qui specialiter ad continentes pertinet. Te sacer o iohannes ornant cumulata centeno fructu quia palmam centesimi fructus uirgines accipiunt" (Paris, BNF, MS lat. 11550, fol. 272v).

56. Matthew 13:23: "qui vero in terra bona seminatus est hic est qui audit verbum et intellegit et fructum adfert et facit aliud quidem centum aliud autem sexaginta porro aliud triginta." 
and medieval writers, conferred hundredfold status on virgins, sixtyfold on widows and celibates, and thirtyfold on married people; this interpretation is the one conveyed by the marginal gloss in the Northern French hymnaries, all of which date from around the middle of the eleventh century. ${ }^{57}$ The gloss not only exalts the status of virginity, but also explicitly contrasts virginity with the chaste-albeit not necessarily virginal-state of celibates and clergy. In the early eleventh century, before the enforcement of clerical celibacy by the Gregorian reform, the ideal of virginity promoted by monastic reformers distinguished monks from the secular clergy, who represented the episcopal control from which monasteries increasingly sought independence. Abbo of Fleury, one of the most influential monastic writers around the year 1000, not only advocated a clear distinction between clergy and laity through celibacy among the secular clergy, but also asserted the superiority of virgins or nuns to abstinent or widowed people, who are in turn superior to married couples. ${ }^{58}$ This scheme corresponds to the tripartite division set forth by Jerome in his commentary on the parable of the sower and the seed. By placing virgins at the top of the hierarchy, the gloss on "Ut queant laxis" could help instill in monks the societal ideas propagated by monastic reformers. ${ }^{59}$

Glosses on "Ut queant laxis" illustrate the didactic function of the hymn text as a vehicle for theological as well as linguistic and musical knowledge; they point to the intersection of grammatical and monastic culture in this hymn. As we have seen, the allusion to the parable of the sower and the seed uses the example of John the Baptist to represent the paradigm of virginity. The monastic ideals of virginity and asceticism exemplified by John could be transmitted to singers through the process of teaching them the hymn. Glosses on the hymns offer many analogies to the idiosyncratic forms of hymn notation discussed below. They explain aspects of the hymn selectively, perhaps as a reminder of what was most needed or useful in teaching students.

57. Jerome, Commentariorum in euangelium Matthaei libri IV, II.805, ed. D. Hurst and M. Adriaen (Turnhout: Brepols, 1969), 105-6; see also Augustine, Quaestiones euangeliorum, I.ix.2, ed. Almut Mutzenbecher (Turnhout: Brepols, 1980), 13. On this parable and its interpretation, see Stephen Wailes, Medieval Allegories of Jesus' Parables (Berkeley and Los Angeles: University of California Press, 1987), 96-103; and Giles Constable, "The Orders of Society," in his Three Studies in Medieval Religious and Social Thought (Cambridge: Cambridge University Press, 1995), 265. The Northern French glossed hymnaries are Amiens, Bibliothèque Municipale, MS 131 (1040-50); Paris, BNF, MS lat. 103 (ca. 1050); and Paris, BNF, MS lat. 11550 (ca. 1040-50).

58. Elizabeth Dachowski, "Tertius est optimus: Marriage, Continence, and Virginity in the Politics of Late Tenth- and Early Eleventh-Century Francia," in Medieval Purity and Piety: Esays on Medieval Clerical Celibacy and Religious Reform, ed. Michael Frassetto (New York and London: Garland, 1998), 117-29; and Constable, Three Studies, 283.

59. Virginity was central to the spiritual and physical education of monks at Cluny in the eleventh century; see Isabelle Cochelin, "Le dur apprentissage de la virginité: Cluny, XIe siècle," in Au cloître et dans le monde: Femmes, hommes et sociétés (IXe-XVe siècle). Mélanges en l'bonneur de Paulette L'Hermite-Leclercq, ed. Patrick Henriet and Anne-Marie Legras (Paris: Presses de l'Université de Paris-Sorbonne, 2000), 119-32. 
Just as glosses provide information on how the texts of hymns were understood in the eleventh century, notation reveals how some singers understood their melodies.

\section{The Notation of Hymns in the Early Sources}

Since the Office hymns have long occupied a rather marginal place in the discipline of musicology, no thorough or systematic survey of early hymn notation has been undertaken before. Moreover, most musicological scholarship on the hymns ignores the fact that the distinctive format of hymnaries, comparable to that of poetic anthologies, reflects the hymns' place in literary and grammatical traditions. ${ }^{60}$ The editions of hymn melodies published in the twentieth century do not communicate the specificity of the manuscript sources, tending instead to publish the melody of a single strophe without considering the diversity of notational types or examining the assumption that all melody-text pairings were more or less equal. In his monumental 1956 edition of hymn melodies, Bruno Stäblein made some reference to variants between strophes, but he was more interested in the national origins and geographic diffusion of the melodies. His primary goal was to publish transcriptions of single strophes of the melodies from sources with diastematic notation. While the edition remains unsurpassed, it is instructive to take account of the broader context of hymn notation, including the manuscripts with adiastematic notation that Stäblein did not employ in the critical edition.

My overview of notated hymnaries up to the early twelfth century focuses on how hymn melodies were written down, and on why the sources exhibit a wide range of notational practices (see Table 1 ). ${ }^{61}$ The last column of Table 1 lists the types of notation found in hymnaries in three categories: notation of only the first strophe of a hymn, notation of several strophes or parts of them, and notation of all the strophes. Many manuscripts contain all three types of notation, and most include at least two types. The variety of notational styles found in the sources corresponds to a variety of functions, suggesting that one type was not inherently preferred over another, but that each had its own

60. Although the notation of hymnaries has been neglected, their manuscript format has been addressed by Pascale Bourgain in two studies: "Les chansonniers lyriques latins," in Lyrique romane médiévale: La tradition des chansonniers. Actes du colloque de Liège, 1989, ed. Madeleine Tyssens (Liège: Faculté de Philosophie et Lettres de l'Université de Liège, 1991), 61-84; and "Les receuils carolingiens de poésie rhythmique," in De Tertullien aux Mozarabes, ed. Louis Holtz and Jean-Claude Fredouille, with Marie-Hélène Jullien (Paris: Institut des études augustiniennes, 1992), 1:117-27.

61. The term hymnary as used here implies a liturgically complete hymn collection and excludes nonliturgical poetic miscellanies containing only a few hymns. Hymns are found in separate hymnaries, where they are the primary contents; in psalters, where they constitute a section of the larger collection; and in breviaries, where they are interspersed among the other elements of the Divine Office. 


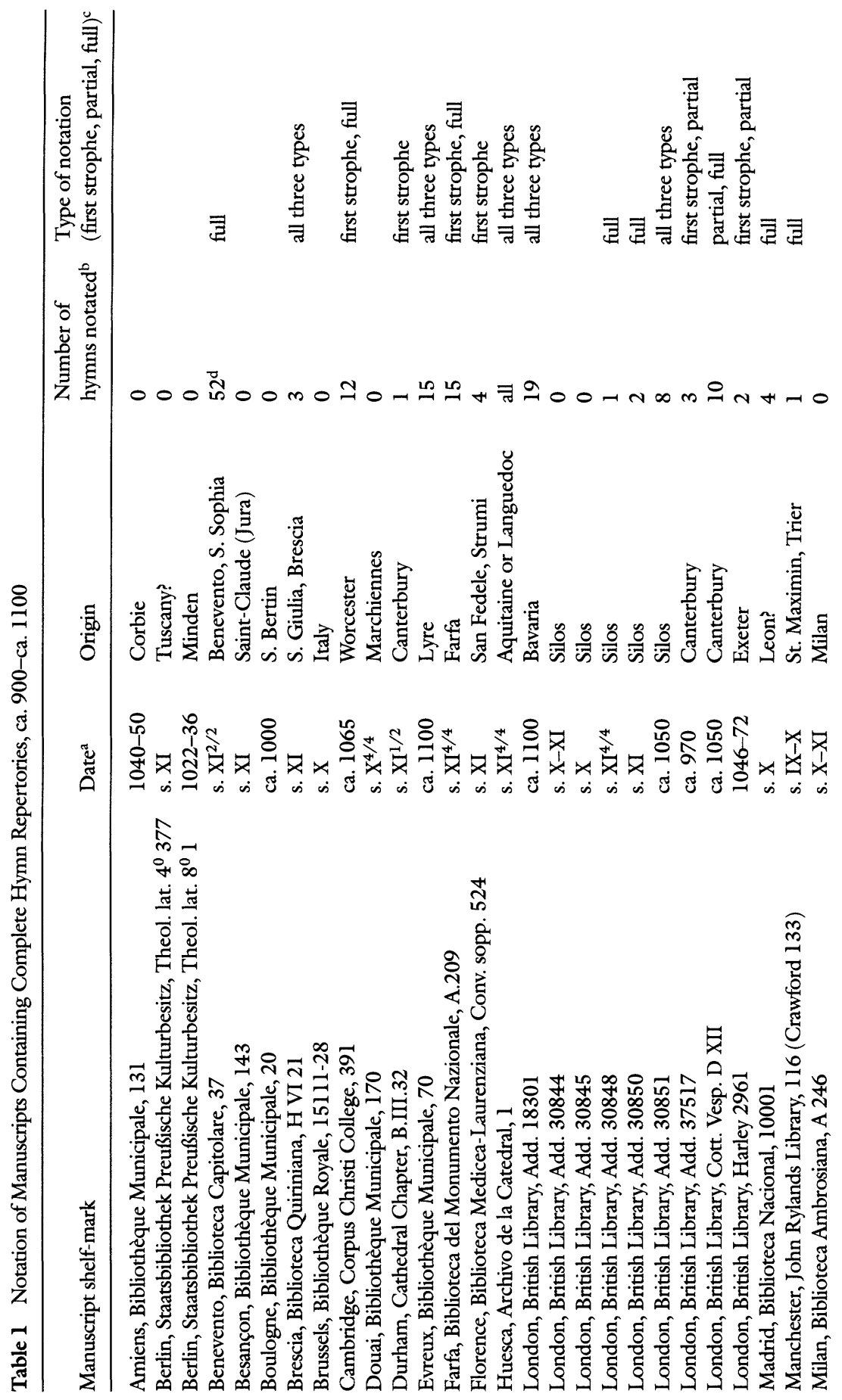




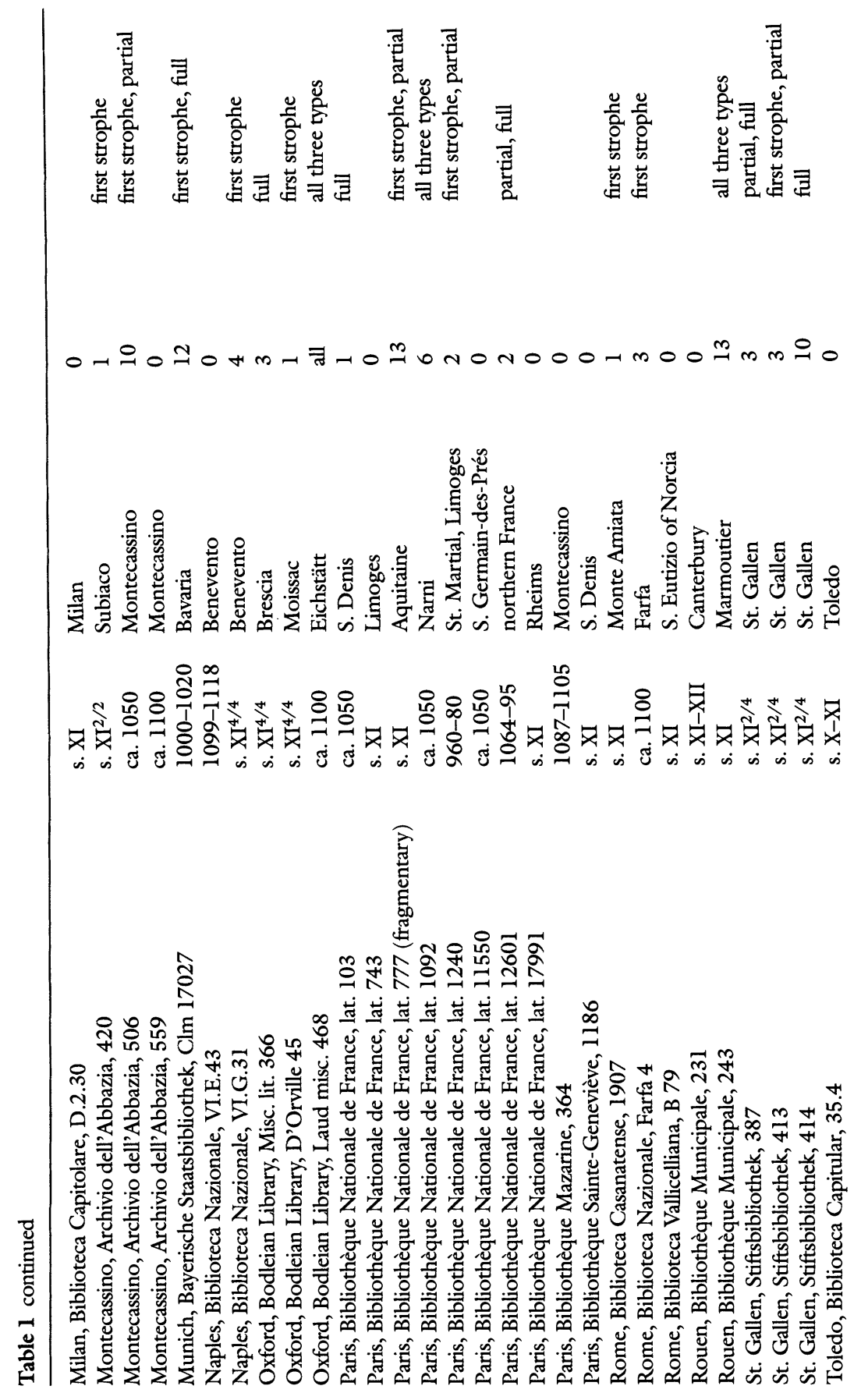




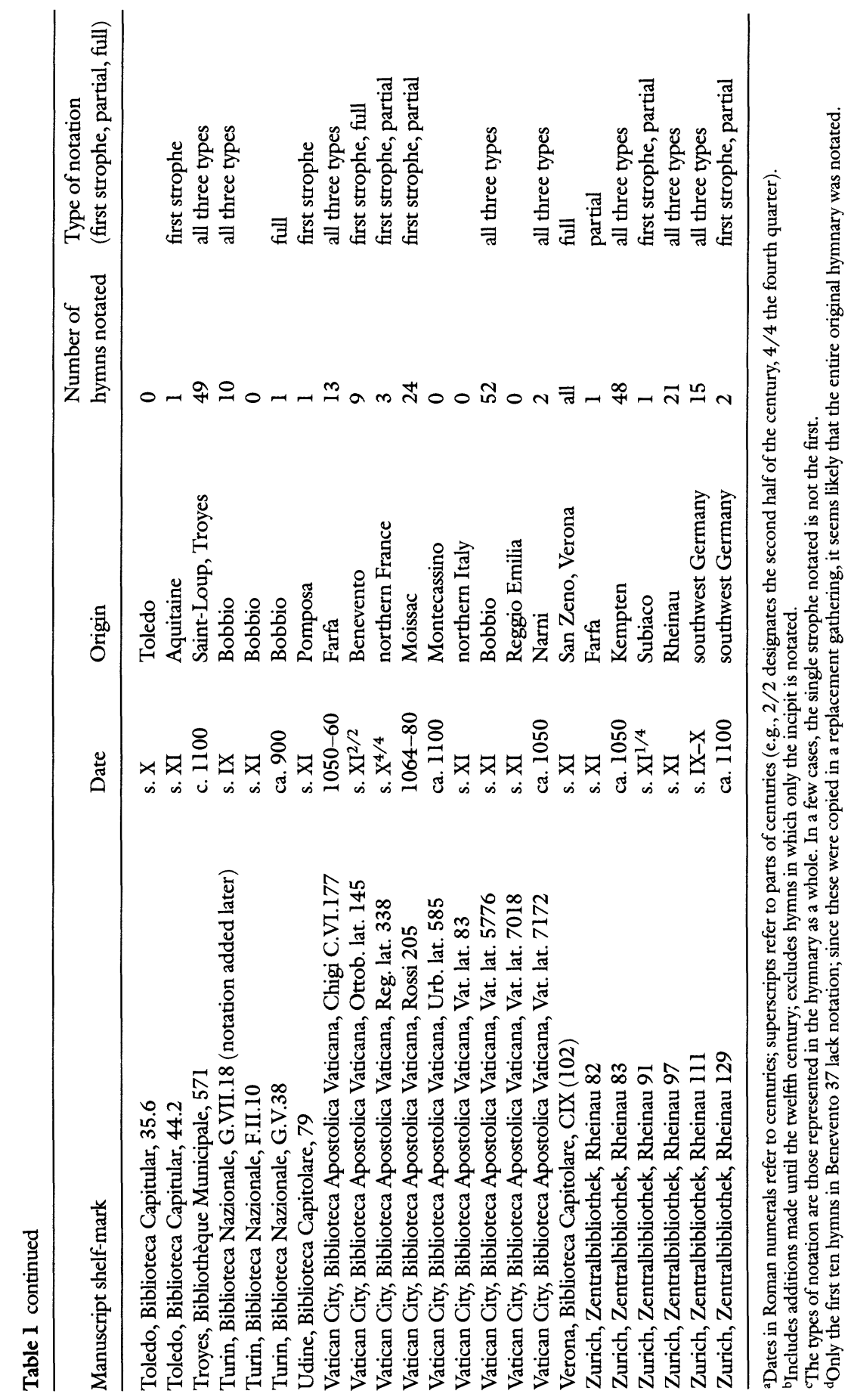


purpose. The remarkable diversity of approaches to notating melodies within a single manuscript has no analogy in other chant repertories. Hymnaries thus offer an unusually large amount of information concerning varying notational practices. I will discuss in turn the three main types of notation: full notation, partial notation, and the notation of single strophes.

\section{Full notation}

Completely notated hymns constitute some of the earliest examples of Latin hymn notation to have survived. Three manuscripts from the tenth century illustrate the nature of this practice. In a ninth-century hymnary from St. Maximin in Trier (Manchester, John Rylands Library, MS 116), "Deus tuorum militum" is the only one of the volume's seventy-four hymn texts to be fully notated, apparently in the tenth century. ${ }^{62} \mathrm{~A}$ mid-tenth-century Mozarabic hymnary (Madrid, Biblioteca Nacional, MS 10001) contains four hymns characteristic of the Old Hispanic repertory that are notated in their entirety. ${ }^{63}$ In addition to selective notation of hymns within complete repertories, sometimes hymns were an entirely new addition to a manuscript: in the tenth century, an insular scribe at the abbey of Lorsch added the fully neumed hymn "Rex gloriose martyrum" in the upper margin of a ninth-century manuscript written by an insular scribe in the Rhineland (Vatican City, BAV, MS Pal. lat. 220). ${ }^{64}$

While these are early examples, complete notation of hymns is found in manuscripts from the entire central Middle Ages. Why did so many notators find it useful to write out complete hymn melodies when there were relatively few differences between strophes? Since hymns are strophic, we might assume that a medieval singer, having assimilated the conventions of hymn performance, could adapt the melody to each successive strophe without difficulty. Nevertheless, singing a hymn entails constant adjustments to the relationship between melody and text, for text placement and accentuation as well as melodic grouping can differ from one strophe to another. The existence of completely notated hymns suggests that precisely these issues arose, requiring clarification of particular portions or aspects of the melodies. In this period, the primary user of a hymn manuscript would be the cantor, for whom the notation of the book would serve as a reference and a reminder of what to emphasize in teaching the hymns to others.

In addition to adjusting the text-music relationship with each strophe, the singer of a hymn had to make melodic alterations of various kinds. Some significant melodic variants between strophes appear in fully notated hymns;

62. On this manuscript, see Jullien, "Les sources," 100-101.

63. "Agnete festum" (p. 28), "Alleluia piis edite" (p. 42), "Puer hic sonat" (p. 66), and "Plebs deo dicata" (pp. 88-89). On this manuscript, see Jullien, "Les sources," 80-81.

64. On this curious manuscript, see Robert McNally, “' 'In nomine dei summi': Seven Hiberno-Latin Sermons," Traditio 35 (1979): 121-22; and Bannister, Monumenti vaticani, 10. 
these variants were lost to written transmission when the practice of notating only the first strophe became standard in the high Middle Ages. The indication of liquescence, a vocal nuance called for by the presence of a nasal or liquid consonant, constitutes the most common variant between strophes of a hymn. Eleventh-century notators did not indicate liquescences with great consistency, and Guido of Arezzo observed that the interpretation of liquescent neumes was at the discretion of the singer. ${ }^{65}$ Perhaps these neumes functioned more as a suggestion than as a prescription. ${ }^{66}$ Even if expert singers made performance choices without difficulty, early hymn sources suggest that the explicit indication of liquescence was sometimes desirable. Liquescents often do not occur at the same point in corresponding strophes of a hymn, so the notation of all the strophes may have functioned as a reminder or a demonstration of the musical rendition of liquescent consonants.

Even in the absence of variants, entire hymn texts were frequently notated in full. This apparently redundant complete notation may have been intended to demonstrate the form and structure of the hymn explicitly, as a guide to performers. The fact that processional hymns are also fully notated in a number of eleventh-century manuscripts supports this supposition. In the eleventh-century gradual written at Albi for St. Michel de Gaillac (Paris, BNF, MS lat. 776), both "Pange lingua" and its divisio "Lustra sex" are notated completely (fol. $123 \mathrm{r}-\mathrm{v}$ ). In the roughly contemporary manuscript from Saint-Maur-des-Fossés (Paris, BNF, MS lat. 12584), the text of "Pange lingua" is written out so as to show that the strophe "Crux fidelis" is repeated as a refrain after each strophe (fol. $377 \mathrm{v}$ ); in the processional hymn "Tellus ac ethra" in the same manuscript, the incipit alone is repeated as a refrain, fully notated, after each strophe (fol. 376r). The processional hymn for Palm Sunday, "Gloria laus," exhibits a similar format in both Paris 776 and Paris 12584 , with the refrain "Gloria" abbreviated and notated after each strophe. In Paris 776, however, only the first word is repeated (fol. 104r), while in Paris 12584 the refrain varies considerably in length and extent of notation, ranging from the single word "Gloria" to the more extended phrase "Gloria laus et honor tibi sit" (fol. 375r-v).

Sometimes the complete notation of a hymn signals its special importance to the institution that produced the manuscript, particularly when the hymn stands out in a book that otherwise contains little notation. For example, a hymn for Saint Ebrulphus, "Summi regis potentia" (fol. 149r), is the only extensively notated hymn in an early twelfth-century psalter-hymnary from the Norman abbey of Lyre in the diocese of Evreux (Evreux, Bibliothèque Municipale, MS 70). ${ }^{67}$ This text, apparently unique to the manuscript, is

65. Timothy McGee, The Sound of Medieval Song: Ornamentation and Vocal Style According to the Treatises (Oxford: Clarendon, 1998), 46-49.

66. Andreas Haug, "Zur Interpretation der Liqueszenzneumen," Archiv für Musikwissenschaft 50 (1993): 85-100.

67. Although the manuscript was produced at Lyre, the litanies reflect the usage of SaintOuen de Rouen (Leroquais, Les psautiers 1:196-97). Evreux 70 may be the psalter listed in the 
notated in its entirety with a relatively ornate melody in unheighted neumes. ${ }^{68}$ The hymn seems likely to have been of recent composition at the time it was copied, for the cult of Ebrulphus took on importance particularly in the eleventh and twelfth centuries. ${ }^{69} \mathrm{He}$ was not the patron saint of Lyre, however; the abbey was founded in 1046 by Count William of Normandy, and the new church was dedicated to the Virgin Mary at its completion in $1050 .^{70}$ The presence of a hymn for Ebrulphus in the manuscript probably reflects Lyre's connection with Saint-Evroul, which provided Lyre with six of its first seven abbots. ${ }^{71}$ These historical circumstances provide an explanation for hymn notation that is exceptional in the context of the manuscript.

An Office manuscript from Sankt Willibald of Eichstätt, copied around 1100 (Oxford, Bodleian Library, MS Laud misc. 468), offers another example of notation related to local saints' cults. ${ }^{72}$ Only two texts in the hymnary section are notated in their entirety: "Omnes superni ordines" for All Saints' (fol. 6v) and "Mare, fons ostium" (fols. 4v-5r) for the patron saint, Willibald. Both "Omnes superni" and "Mare, fons" are attributed by the testimony of an eleventh-century chronicler to Heribertus, bishop of Eichstätt, who died in 1042.73 Since very few sources of these hymns are known from the twelfth century, the Oxford manuscript from Sankt Willibald is certainly among the earliest witnesses to the texts. The complete notation of these particular hymns contrasts with the variable but mostly limited amount of notation added to other hymns in the collection; in most cases only one or two strophes are

twelfth-century catalogue of the library at Lyre; see Henri Omont, Rouen, vols. 1-2 of Catalogue général des manuscrits des bibliothèques publiques de France, Départements (Paris: Plon, 1886-88), 2:381.

68. See Analecta hymnica medii aevi, vol. 12, Hymni inediti: Liturgische Hymnen des Mittelalters, ed. Guido Maria Dreves (Leipzig: O. R. Reisland, 1892), 108-9; and James Mearns, Early Latin Hymnaries (Cambridge: Cambridge University Press, 1913), 83.

69. Ebrulphus, whose feast is celebrated on December 29, was a Merovingian abbot of Ouche; see Paul Viard, "Ebrulfo," in Bibliotheca sanctorum, vol. 4 (Rome: Società grafica romana, 1964), cols. 893-94. Much of the hagiography regarding this saint dates from the eleventh century.

70. Laurent-Henri Cottineau, Répertoire topo-bibliographique des abbayes et prieurés (Mâcon: Protat, 1939), vol. 1, col. 1694.

71. See Charles Guéry, Histoire de l'Abbaye de Lyre (Evreux: Imprimerie de l'Eure, 1917), 21-24; Geneviève Nortier, Les bibliothèques médiévales des abbayes bénédictines de Normandie (Paris: Lethielleux, 1971), 124; and Cassandra Potts, Monastic Revival and Regional Identity in Early Normandy (Woodbridge: Boydell, 1997), 118. Nortier lists Evreux 70 among the products of the scriptorium of Lyre (Les bibliothèques, 141). Guéry describes the manuscript and prints the text of the hymn (Histoire, 349-50).

72. According to Stephen Joseph Peter van Dijk, "Handlist of the Latin Liturgical Manuscripts in the Bodleian Library, Oxford," vol. 2/ii (Oxford, Bodleian Library, 1957, typescript), the manuscript was copied after 1108 because the Easter tables extend from 1108 to 1139. The hymnary, however, was copied by a slightly earlier hand than the Easter tables (fol. $3 \mathrm{v}$ ).

73. The texts are edited in Analecta Hymnica, vol. 50, Hymnographi latini: Lateinische Hymnendichter des Mittelalters, Zweite Folge, ed. Guido Maria Dreves (Leipzig: O. R. Reisland, 1907), 290-301, with "Mare, fons" on pp. 292-93. 
notated. The decision to notate just these two hymns in their entirety was probably based on their status as works of recent composition, one of them celebrating the patron saint.

In some cases, we know that a particular hymn was a recent composition at the time it was copied and notated, and the types of notation used for such works show how notators approached new material. The notation in the early sources of Peter Damian's hymns is particularly instructive in this regard. ${ }^{74}$ The earliest complete source of the hymns is Vatican City, BAV, MS Vat. lat. 3797 , which contains all his poetic and liturgical compositions as well as many of his prose works..$^{75}$ In this codex, the notationless texts of the hymns are distinguished from the notated versions by their separate location and contrasting format. The same scribe who copied the complete texts in prose format on folios 36lv-366v also copied the first strophes of the hymns again (fols. $372 \mathrm{r}-373 \mathrm{r}$ ) in a smaller script. At least two different hands notated most of the melodies with late eleventh-century central Italian neumes oriented around the drypoint lines. ${ }^{76}$ It is clear that this section of the manuscript was designed for the sole purpose of recording the melodies of the hymns. Since the texts are available in their entirety in the previous section, the recopying of the first strophes would be inexplicably redundant unless they were intended to be notated. It is striking, therefore, that not all the hymns are notated, despite the careful planning and evident compression of the notated hymn section of the manuscript. While the dimensions of the manuscript page are generous, the notated liturgical texts are copied in a curiously compressed format, with no distinction between verses within strophes, nor indeed between the individual strophes themselves (and thus between the different hymns). The following section of the manuscript, which contains other Office chants as well as tropes, prosulae, and sequences, is much more clearly laid out and fully rubricated; the text scribe, who determined the mise-en-page, is the same as in the hymn section.

74. Peter Damian (d. 1072) was one of the foremost reformers and polemicists of the eleventh century, promoting both monastic reform as prior of Fonte Avellana and the Gregorian reform as the cardinal-bishop of Ostia. Among the least known of his extensive writings are his hymns and other liturgical poems; see Margareta Lokrantz, ed., L'opera poetica di s. Pier Damiani (Stockholm: Almqvist \& Wiksell, 1964).

75. The manuscript belonged to the monastery of Santa Maria outside Faenza, where Peter Damian died. On the manuscript's history and contents, see Owen Blum, "Alberic of Monte Cassino and the Hymns and Rhythms Attributed to Saint Peter Damian," Traditio 12 (1956): 103-8; Lokrantz, ed., L'opera poetica, 9-12; Giovanni Lucchesi, "Per la storia faentina del cod. Vat. Lat. 3797," in San Pier Damiano nel IX centenario della morte, 1072-1972, vol. 3 (Cesena: Centro studi e ricerche sulla antica provincia ecclesiastica ravennate, 1973), 207-12; Kurt Reindel, "Studien zur Überlieferung der Werke des Petrus Damiani, I," Deutsches Archiv für Erforschung des Mittelalters 15 (1959): 68-79; idem, "Zur handschriftlichen Überlieferung der Gedichte des Petrus Damiani," Revue bénédictine 67 (1957): 182-89; and André Wilmart, "Le recueil des poèmes et des prières de saint Pierre Damien," Revue bénédictine 41 (1929): 342-57.

76. On the notation, see Bannister, Monumenti vaticani, 143, no. 432. 
Various reasons for the omission of hymn melodies can be imagined, including the fact that this section of the book was apparently never completed. ${ }^{77}$ Since the notational hands seem somewhat later than the text, perhaps hymn melodies were added not all at once, but over time, as they became available. Henry Marriott Bannister proposed that the texts left without notation would have been sung to the same melody as other hymns of the same meter. ${ }^{78}$ The idiosyncratic format of the notated section makes it unlikely, however, that the scribe would have chosen to include texts in this section that were not destined to be notated. After all, Vat. lat. 3797 contains not a generic liturgical repertory, but rather a collection of new compositions attributed to a venerated churchman and intellectual. ${ }^{79}$ The manuscript seems to have been copied by a close associate of Peter Damian, and indeed some details of the format may indicate that the text scribe knew the melodies rather well..$^{80}$ Since only one strophe of most hymns was copied, the entire composition did not need to be recorded in order to demonstrate how the melody fit the text. In the case of the hymn "Celum terra pontus," however, the scribe chose to copy two strophes, perhaps in order to illustrate subtle melodic variants between them.

The incomplete notation of Peter Damian's hymns in Vat. lat. 3797 may reflect the complex transmission of the melodies during his lifetime and soon after his death. Some melodies that are notated in the Vatican manuscript are not found in other early sources, while others that are left without notation in the Vatican manuscript are notated in other eleventh-century manuscripts. ${ }^{81} \mathrm{~A}$ group of hymns for the Little Office of the Virgin Mary with the incipit "Beata Dei genitrix," 82 which is not notated in Vat. lat. 3797, appears in a late eleventh-century gradual from Cluny (Paris, BNF, MS lat. 1087) that illustrates the sometimes idiosyncratic format employed for hymns of recent composition. In the Cluny gradual, the complete text of the hymn is copied

77. The initial letters of each hymn have not been filled in, and a large space is left blank in the right-hand column of folio 372r, perhaps for another hymn or a large decorated initial.

78. Henry Marriott Bannister, [untitled], in Rassegna gregoriana 7 (1908): 262-64.

79. Blum argues that seventeen of the poems ascribed to Peter Damian in Vat. lat. 3797 were actually written by Alberic of Montecassino ("Alberic of Montecassino"), but I follow Lokrantz in attributing them to Peter Damian.

80. Lokrantz, ed., L'opera poetica, 10.

81. Montecassino, Archivio dell'Abbazia, MS 420 contains a notated version of "Aurora surgit aurea," which is not notated in Vat. lat. 3797. Another notated version of "O genitrix" is found in Vatican City, BAV, MS Chigi C.VI.177, which is among the earliest witnesses to some of Peter Damian's hymns; see Susan Boynton, "Liturgy and History at the Abbey of Farfa in the Late Eleventh Century: Hymns of Peter Damian and Other Additions to BAV Chigi C.VI.177," Sacris erudiri 39 (2000): 253-80. "O genitrix" was also added in the second half of the eleventh century to a hymnary produced in the mid-eleventh century at Canterbury (London, British Library, MS Cotton Julius A.VI, fol. 90r); the only notated hymn in the book, it was neumed in full by a French hand, probably because the piece was a new addition to the repertory after the Norman Conquest.

82. Lokrantz, ed., L'opera poetica, 124-26. 
on folio $115 \mathrm{v}$, followed on folio $116 \mathrm{r}$ by melodies in Aquitanian notation for each strophe. The notated version indicates the text by only the first letter of each word. This approach to text placement resembles to some degree the textless melismatic notation employed for sequences, showing that notators sometimes resorted to unconventional techniques for writing down the melodies of Office hymns. ${ }^{83}$ The unusual format of the hymn "Beata Dei genitrix" illustrates the particular care often given to the notation of new compositions. ${ }^{84}$ Another, rarer form of full notation that appears in only a few manuscripts occurs when scribes copied different melodies for successive strophes within a single hymn, in order to show the variety of melodies that could be sung to the same text. The Huesca hymnary (Huesca, Archivo de la Catedral, MS 1) is the only manuscript that consistently provides multiple melodies for successive strophes within individual hymns. ${ }^{85}$

\section{Partial notation}

Notation of only parts of a hymn strophe, of parts of several strophes, or of a few strophes in their entirety implies that the notator selected portions of the melody that required particular attention. The phenomenon of partial notation, which appears rarely outside the hymn repertory, ${ }^{86}$ suggests that singers

83. Boynton, "Glossed Hymns," 81.

84. Sometimes a new melody has only partial notation. For instance, in the Office for Mary Magdalen added around 1100 to a manuscript from Saint-Maur-des-Fossés (Paris, BNF, MS lat. 12584 , fol. $214 \mathrm{v}$ ), the first strophe of "Fidelium devotio" is notated, while the contrasting melody of the divisio, "Maria fusis crinibus," is notated only for the first eight syllables, apparently just enough to indicate that the divisio should be sung to a melody that was different from that in the first part of the hymn. The texts are edited in Analecta bymnica, vol. 2, Hymnarius moissiacensis: Das Hymnar der Abtei Moissac im 10. Jabrhundert, ed. Guido Maria Dreves (Leipzig: O. R. Reisland, 1888), 97-98.

85. The Huesca hymnary was copied probably in southern France and brought to Aragon by around 1100 , perhaps to introduce a new hymn repertory, which could be the reason for both the multiple melodies and the abundant Latin glosses in the manuscript. For a recent description of the manuscript, see Susan Boynton, "Eleventh-Century Continental Hymnaries Containing Latin Glosses," Scriptorium 53 (1999): 248-51. While the systematic use of multiple successive melodies seems unique to the Huesca hymnary, individual hymns are also notated with multiple melodies in Einsiedeln, Stiftsbibliothek, MS 366, p. 37 (successive strophes of "Iam lucis orto sidere"), and Utrecht, Bibliotheek der Rijksuniversiteit, MS 406 (3.J.7), fol. 47r (alternate melodies for the second strophe of "Rector potens" and of "Rerum Deus").

86. For examples in manuscripts of the Old Hispanic chant, see Louis Brou, "Notes de paléographie musicale mozarabe," Anuario musical 10 (1955): 23-29. Other examples include Florence, Biblioteca Medicea Laurenziana, MS Amiatino 1, a Bible in which neumes were added to cadential formulas or isolated words or syllables. Lila Collamore brought to my attention the notation of isolated brief segments of text within responsories and verses in an early southern French manuscript, as described by John Emerson in Albi, Bibliothèque Municipale Rochegude, Manuscript 44: A Complete Ninth-Century Gradual and Antiphoner from Southern France, ed. Lila Collamore (Ottawa: Institute of Mediaeval Music, 2002), lix-lxiii. Collamore also pointed out that in Paris, BNF, MS lat. 1085, isolated words or groups of words are notated within 
relied primarily on the oral tradition of the hymns. Several examples of partial notation appear in Cambridge, Corpus Christi College, MS 391, an AngloSaxon Office book produced at Worcester around the time of the Norman Conquest. ${ }^{87}$ In the iambic "Conditor alme siderum" (see Fig. 1), each strophe consists of four eight-syllable lines, all rhyming on -um except for the first line of the second strophe. In these two strophes, the liquescent consonants occur in varying positions within the verses, with the result that liquescences do not occur on corresponding syllables of different strophes.

Conditor alme siderum, aeterna lux credentium, Christe redemptor omnium, exaudi preces supplicum,

Qui condolens interitu mortis perire seculum, saluasti mundum languidum, donans reis remedium.

\author{
Kind creator of the stars, \\ eternal light of believers, \\ Christ, redeemer of all people, \\ hear the prayers of those who beseech \\ you, \\ Who, suffering that the world \\ was perishing in the destruction of death, \\ saved the ailing world, \\ giving a remedy to the guilty.
}

The notator added neumes to the entire first strophe, then skipped the first line of the second strophe, notating only its second line. The neumes over the first two syllables of the first strophe (Condi-, Fig. 1) illustrate a basic distinction in neumatic notation. The cephalicus on Con-indicates a two-note descent, its semicircular shape signaling the liquescence produced by the presence of the nasal consonant $(-n-)$. Over the second syllable $(-d i-)$ is a clivis, its

chants, and often the verses of responsories are notated even when the responds are not, apparently because the book was designed for the use of the cantor, as shown by James Grier, "The Divine Office at Saint-Martial in the Early Eleventh Century: Paris, BNF lat. 1085," in The Divine Office in the Latin Middle Ages: Methodology and Source Studies, Regional Developments, Hagiography, ed. Margot Fassler and Rebecca Baltzer (New York: Oxford University Press, 2000), 179-204; see also Lila Collamore, "Aquitanian Collections of Office Chants: A Comparative Survey" (Ph.D. diss., Catholic University of America, 2000), 41-48. Partial notation also appears in nonliturgical contexts, such as manuscripts of Prudentius: for an example, see Gernot Wieland, "The Prudentius Manuscript CCCC 223," Manuscripta 38 (1994): 214. Jan Ziolkowski shows that partial notation also appears in medieval neumations of classical texts ("Nota Bene: Why the Classics Were Neumed in the Middle Ages," The Journal of Medieval Latin 10 [2000]: 74-114).

87. On this manuscript, see Alice Correa, "The Liturgical Manuscripts of Oswald's Houses," in St. Oswald of Worcester: Life and Influence, ed. Nicholas Brooks and Catherine Cubitt (London and New York: Leicester University Press, 1996), 286; Susan Rankin, "Some Reflections on Liturgical Music at Late Anglo-Saxon Worcester," in ibid., 339-43; and idem, "Neumatic Notations in Anglo-Saxon England," in Musicologie médiévale: Notations et séquences, ed. Michel Huglo (Paris: Champion, 1987), 136. Pam Robinson dates the manuscript to 1064-69 (Catalogue of Dated and Datable Manuscripts c. 737-1600 in Cambridge Libraries [Cambridge: Brewer, 1988], 2, no. 31), while Milfull gives the date as "about 1065" (Hymns of the Anglo-Saxon Church, 43-44). 


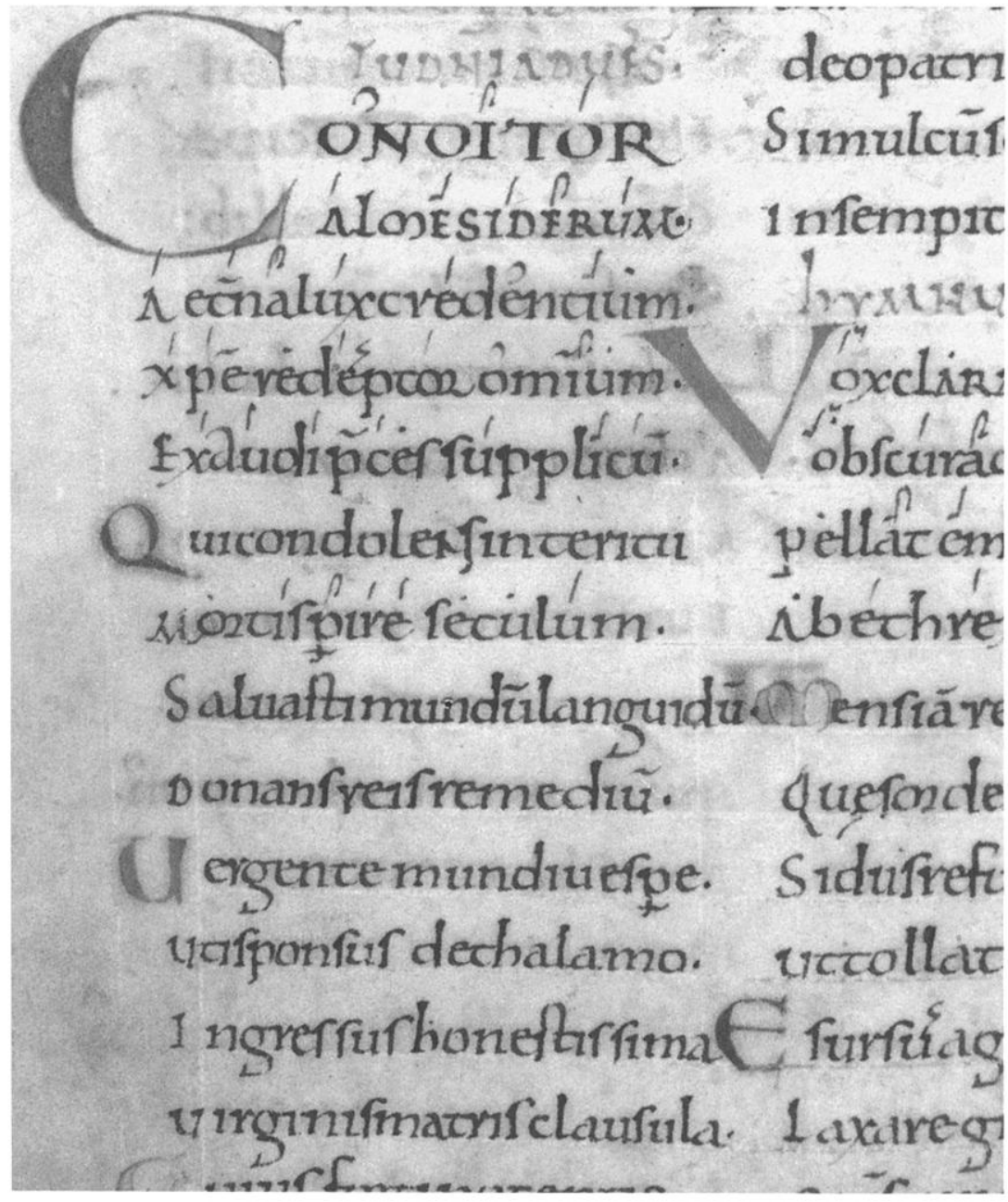

Figure 1 Cambridge, Corpus Christi College, MS 391, p. 238. By permission of the Master and Fellows of Corpus Christi College, Cambridge.

less rounded shape indicating a descent of two notes without a liquescent nuance on this open syllable. The second line of the first strophe (the third line in Figure 1) ends with three neumes over the three syllables -dentium: another cephalicus on -den-, a pes on -ti-indicating a two-note ascent, and a punctum (single note) on -um. The corresponding syllables in the second strophe (seculum; the seventh line in Figure 1) are notated differently, however, with two puncta on secu-, ending on -lum with a virga, suggesting an ascent. Probably the essential melodic contour is the same in both strophes, albeit somewhat 
ornamented in the first. Perhaps the liquescence in the first strophe, called for by the nasal $n$ in -den-, introduced a descent that had to be counteracted by the ascending pes on the next syllable (-ti-), which in turn made it unnecessary to show ascent on the last syllable (-um) with the usual virga, and for this purpose a punctum was sufficient at the conclusion of the first strophe. The adiastematic notation does not permit us to determine the precise intervallic relationships or even the exact contour, but we can see that the two neumations differ. ${ }^{88}$ The notator communicated the difference between these two phrases by notating just enough of the second strophe to distinguish it from the first. ${ }^{89}$

Another hymn in Corpus Christi College 391, "Iam Christus astra ascenderat" (see Fig. 2), shows the notation of two strophes for a different reason, namely a hypermetric line: the first line of the first strophe, "Iam Christus astra ascenderat," has nine syllables, while the corresponding line in the second strophe, "Sollempnis urgebat dies," has the normal number of eight. In reading the hymn aloud according to the rules of classical Latin poetry, it would be correct to elide the -stra of astra with the opening $a$ - of ascenderat, producing a total of only eight syllables. But the musical setting, following the more ordinary medieval pronunciation, assigns a note to each syllable of the text, shown in the manuscript (Fig. 2) as a virga at the end of the first line and another virga at the beginning of the second. To bring the number of syllables back down to the expected eight in the second strophe, the virga and punctum on ascen - in the first strophe are combined into a single neume, the clivis over the syllable -bat (the sixth line in Figure 2)..$^{90}$

Given the tendency toward partial notation among the twelve notated hymns in Corpus Christi College 391, it is striking that the only two completely notated hymns bear Norman-style neumes rather than Anglo-Saxon

88. While the neumes do not permit a definitive identification of the melody, it seems to resemble one notated on staff lines in the thirteenth-century hymnary from Worcester cathedral (Worcester, Cathedral Library, F.160), reproduced in Antiphonaire monastique, XIIIe siècle: Codex F.160 de la Bibliothèque de la Cathédrale de Worcester (Tournai: Desclée, 1922), 1*, and edited in Stäblein, Hymnen, 170. If this is indeed the melody represented in the adiastematic neumes of Figure 1, it would help to explain another notational variant pointed out by Peter Jeffery, namely the puzzling difference between the virga on ae-of aeterna in the first strophe and the punctum on mor- of mortis in the corresponding phrase of the second strophe. If the virga and punctum here refer to the same pitch (which is likely), the notator chose a virga in the first case to indicate the same pitch as the immediately preceding one (on $-u m$ of credentium) while the use of the punctum in the second case was intended to show that the pitch of mor-in mortis was relatively lower than that of - tis.

89. An anonymous reader for this Journal noted that one would expect to see notation on the first line of the second strophe, "Qui condolens interitu," which requires a liquescent on the second syllable but not the first, thereby reversing the placement of liquescences in the first line, "Conditor alme siderum."

90. I am grateful to Ernest Sanders for pointing out to me that the musical setting of the text, which does not elide the word astra, was the cause of the hypermetric line. 


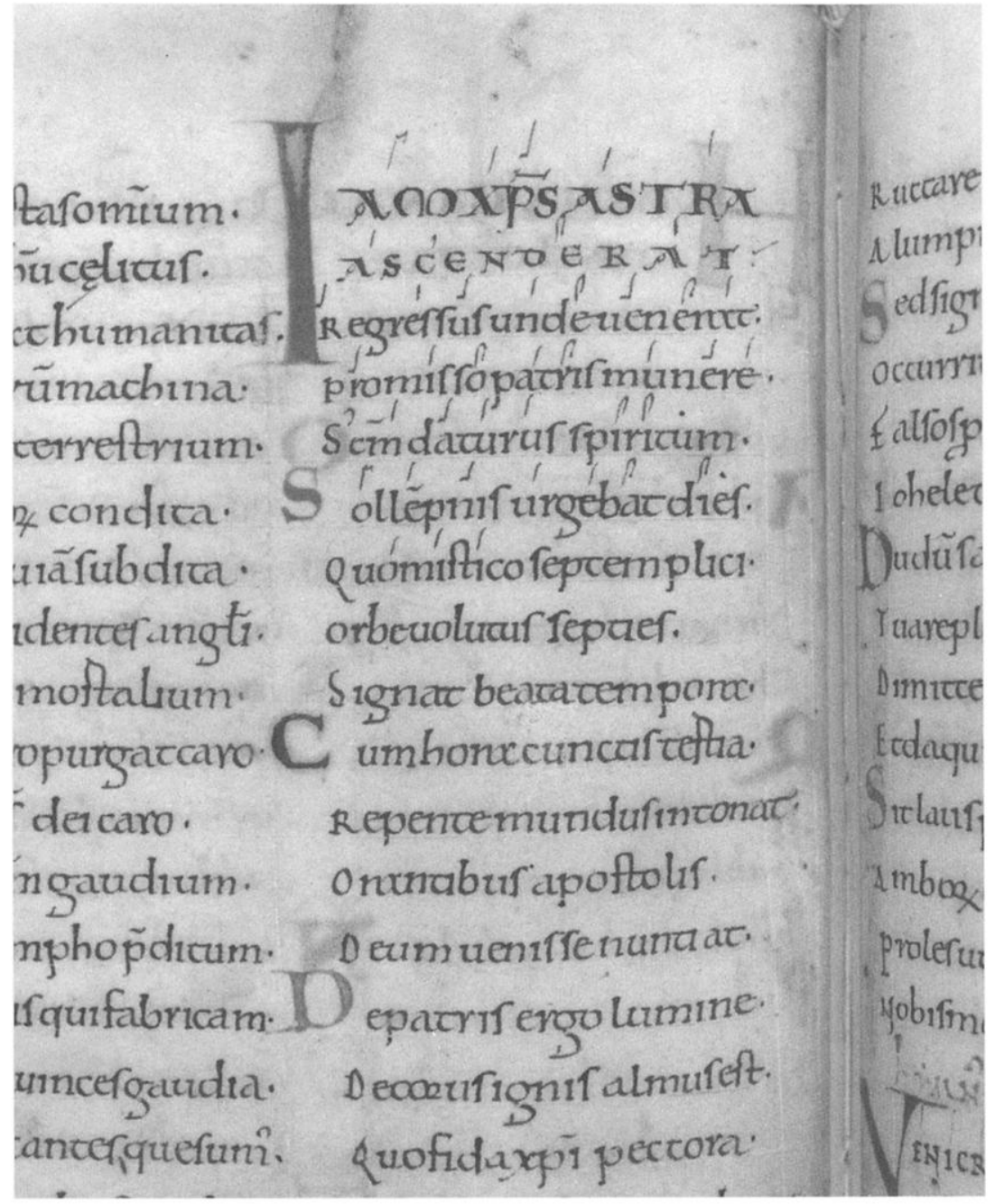

Figure 2 Cambridge, Corpus Christi College, MS 391, p. 250. By permission of the Master and Fellows of Corpus Christi College, Cambridge.

ones ("Audi benigne" on p. 245 and "Quod chorus" on p. 254). Inge Milfull has argued that these neumes were added during the post-conquest revision of the hymnal. ${ }^{91}$ The different approach to notation of the hymns exhibited by the Norman-style neumes could indicate that the Norman notators were not as familiar with Worcester's hymn tradition, or that they willfully altered it by introducing their own melodies.

91. Milfull, Hymns of the Anglo-Saxon Church, 47. 
Although I discuss full-, partial-, and single-strophe notation in separate sections, all three types are in fact frequently found in the same manuscript (see Table 1). Paris, BNF, MS lat. 1092, a mid-eleventh-century hymnary copied in Narni, provides a striking example. Only seven hymns are notated out of more than a hundred in the manuscript. The unheighted neumes, typical of Umbria and Lazio in the eleventh century, demonstrate text-music relationships, ornaments, and general contours rather than indicate pitch or intervallic content. The entirety of "O quam glorifica" (fol. 49v) is notated, perhaps to demonstrate the placement of text in the florid melody. One might attribute differences in notational styles to the preferences of different notators, but in fact the same hand that notated all of "O quam glorifica" took the opposite approach to "Urbs beata hierusalem" (fol. 139v), notating only the first two words, then a phrase in the middle of the first strophe..$^{92}$ Since the two notated phrases within the strophe seem to begin with identical melodies, as far as one can tell from the adiastematic neumes, this partial notation may have been intended to indicate repetition within the melody, while presuming that the rest of it did not require explicit demonstration.

The hymn "Alleluia piis edite laudibus" in this manuscript further demonstrates the use of partial notation (see Fig. 3). Only the first half of the first and seventh strophes are notated, and the notator wrote the melody for the words alleluia perbenne between the lines and in the margins once on each of these two pages. This redundant notation seems intended to clarify the text-setting; the phrase is too florid to fit into the brief space above the word alleluia, which is abbreviated to the first three letters. Moreover, each verse beginning with the phrase alleluia perbenne is hypermetric, with thirteen syllables instead of twelve. The combination of a florid melody with a hypermetric line seems to have led the notator to emphasize this portion of the hymn in an explanatory fashion. The same hand (or a closely related one) notated the other extant mid-eleventh-century hymnary from Narni (Vatican City, BAV, MS Vat. lat. 7172) and similarly employs partial notation. In Vat. lat. 7172, the hymn "Centies mille legionum angelorum" is notated in the same ink as the text for the first two strophes on folio $90 \mathrm{r}-\mathrm{v}$, followed by sporadic single neumes in the next strophe. No more notation appears until a brief passage in the sixth strophe at the top of folio 9lr, in which the scribe apparently exploited the spacious upper margin to clarify the contour of a phrase that had been vertically compressed in its previous appearances, between the lines of text on the first and second pages of the hymn. It is not clear why the same melismatic phrase should be notated several times without any visible variants, but it seems that the repetition was intended to clarify the relationship between melody and text. A hymnary from the abbey of Farfa (Zurich, Zentralbibliothek, MS Rheinau 82) contains an equally intriguing example of partial

92. The only words notated are the ones italicized here: Urbs beata ierusalem dicta pacis uisio que construitur in celis uiuis ex lapidibus et angelis cohornata ut sponsata comiti. 


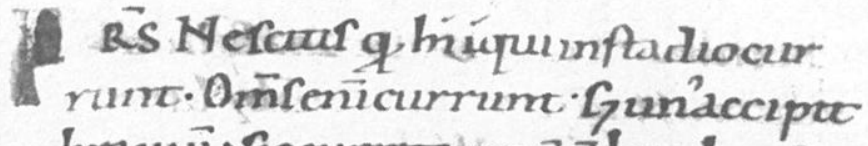

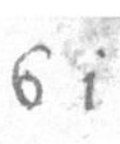

bramungficcurrute utcöp. hendanf.

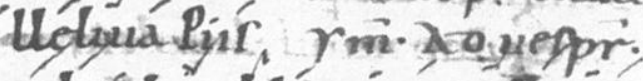

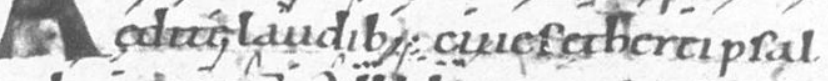

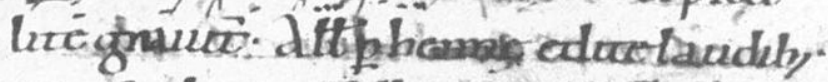
cuer cthercipfallectgaudzid icuor

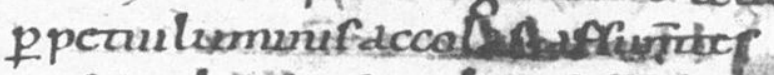

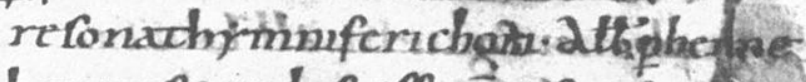
luminiraccolar a flumat refonant brmniferichor $\cdot V$ ofurbrpperua - fufcupredi quederafrofinate cancalspactia dit phennefufoiprea

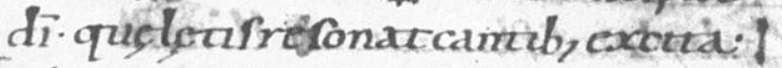

I clucufredduagaudeafumie redden ictdrioglíficormelor. Attpbenncgan diafumme reddenuerdnoglonifico melo.A lmüf frderrü siptinçdedur: uctoref captarquocanorezugr alt phenise sipxeriedecul:aucurefos par quw canorenugh acfentre quer bocej bj alpour boclezant reducent hoftib afflure atto henne hoccib, o pour? hoclezan ratucenr

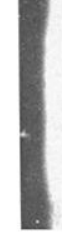

Figure 3 Paris, Bibliothèque Nationale de France, MS lat. 1092, fol. 6lr-v. By permission of the Bibliothèque Nationale de France. 


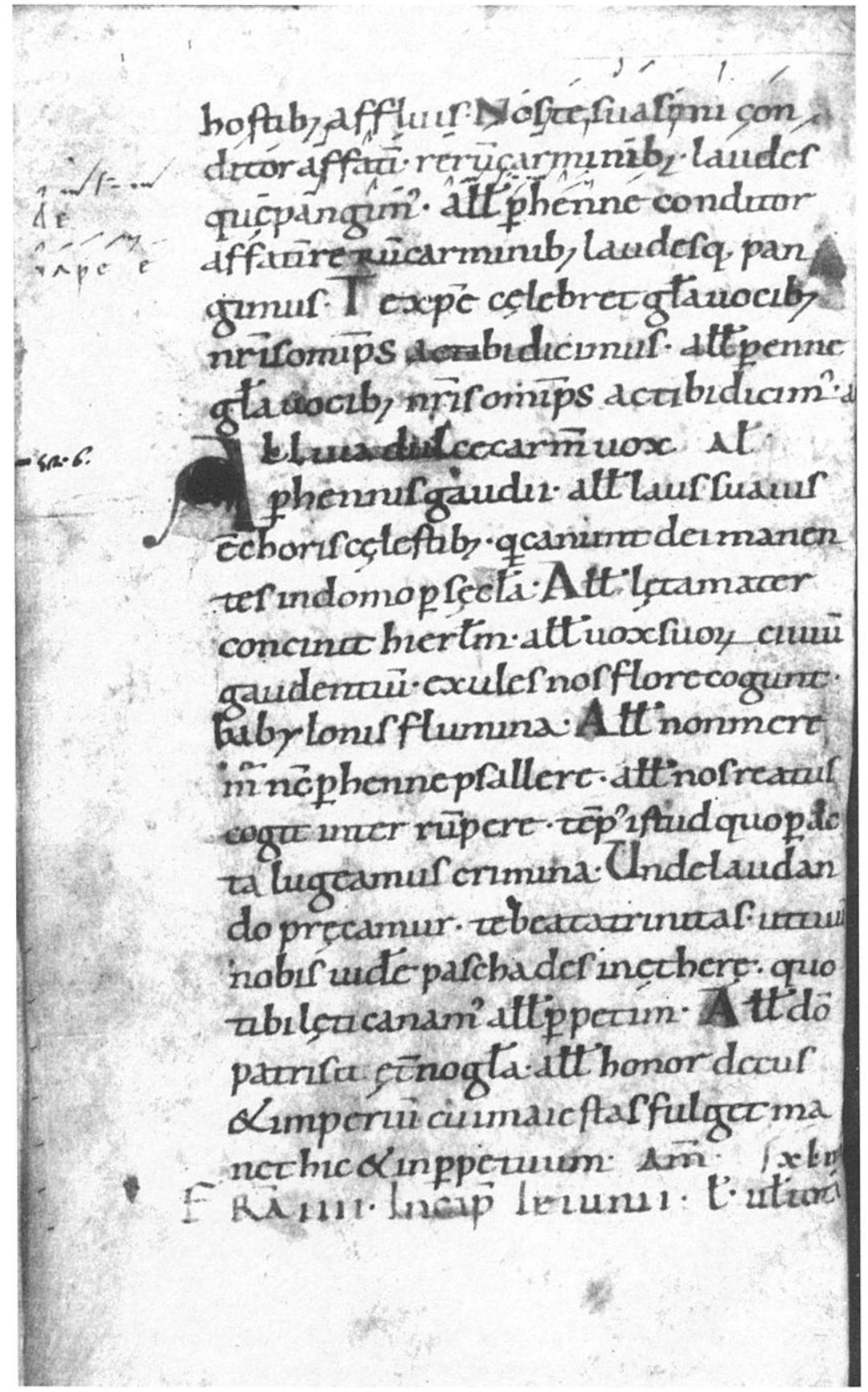

Figure 3 continued 
notation: only the fourth and fifth strophes of "Apostolorum passio" (pp. 8485) have been notated in adiastematic Latian neumes.

Some examples of partial notation seem intended to serve as a guide to distinctive performance practices. In the unusual case of the hymn "Felix per omnes" for Saints Peter and Paul, in which two different melodies can be sung to alternate strophes, the notator of a manuscript copied at the abbey of Moissac in the third quarter of the eleventh century doggedly indicated a melodic incipit at the beginning of each strophe, in order to render perfectly clear the alternation of the two melodies. ${ }^{93}$ Partial notation, with its special nuances and explanatory character, suggests a different relationship to the oral tradition than notation of a hymn's first strophe, which later became the predominant type.

\section{Notation of only the first strophe}

Notation of the first strophe alone was apparently the last to develop of the three types of hymn notation discussed here. The succinct character of singlestrophe notation in comparison to full and partial notation can be interpreted in various ways. The users of manuscripts may not have always required the explicit demonstration of a hymn's structure provided by complete notation. Perhaps the practice of performing variants between strophes, as reflected in the earlier manuscripts, was at the discretion of singers, eliminating the need for partial or full notation; over time, singers may have ceased to vary hymns from strophe to strophe. As with all notation, we cannot be sure of the precise relationship between performance and the written record. Whatever the explanation, notation of the first strophe became almost standard in the twelfth century. A striking example of this change is the contrast between a twelfthcentury southern Italian manuscript (Benevento, Biblioteca Capitolare, MS 42 ) and a closely related hymnary from a century earlier (contained in Benevento, Biblioteca Capitolare, MS 37). While all the hymns in Benevento 37 are fully notated, with liquescences indicated in each strophe, in Benevento 42 only the first strophe of each hymn is notated, creating a different representation of the hymn melody. ${ }^{44}$ Both were produced for the same community, the abbey of Santa Sofia in Benevento; the later manuscript reflects different priorities from those of the earlier one.

The most unusual method of notating a single strophe of a hymn melody is the textless marginal notation found in some manuscripts from the late eleventh and early twelfth centuries. Such marginal notation often specifies

93. Vatican City, BAV Rossi 205, fols. 21r-22r. For a description of this manuscript, see Boynton, "Eleventh-Century Continental Hymnaries," 222-28.

94. On this manuscript, see Jean Mallet and André Thibaut, Les manuscrits en écriture bénéventaine de la Bibliothèque Capitulaire de Bénépent (Paris and Turnhout: CNRS/Brepols, 1997), 1:255-80; on the hymns, see pp. 263-77. 
pitch content and phrasing to a greater degree than was possible in interlinear notation..$^{95}$ Marginal notation can show the shape and intervallic content of a melody, but separates it radically from the text; particularly when the notation is perpendicular to the text, it prevents the user of the manuscript from viewing text and melody simultaneously. The use of textless marginal notation implies that a clear indication of text underlay was less important to the notator than a fully heightened version of the melody. For instance, a late eleventhcentury manuscript from Benevento (Vatican City, BAV, MS Ottob. lat. 145) was apparently not designed to be notated, but several melodies were added in the form of textless adiastematic neumes in the margin, often perpendicular to the texts. Only in one hymn in Ottob. lat. 145, "Festum nunc celebre" (fol. $53 \mathrm{v}$ ), did the notator choose to add neumes between the lines. Another hymn, "Confessor Domini Maure" (fol. 134r), was added to the manuscript slightly later, around 1100, with neumes oriented around a drypoint line. The difference between the textless marginal notation, clearly an afterthought, and the more detailed musical record of "Confessor Domini Maure" reflects the passage of time from copying a hymn text with no intention of notating it to planning for a fully notated hymn.

The contrast between textless marginal notation and full notation of all strophes of a hymn can be compared to analogous notational types found in early sequence manuscripts. Sequentiaries can include two differently notated versions of each melody on the same page or in distinct sections of a manuscript. When on the same page, untexted melismatic notation in the margins corresponds to the melody written between the lines of text at the center of the page. The textless marginal version of the melody shows contours and phrasing, while the syllabic one shows text placement. ${ }^{96}$ Hymnaries usually do not combine these two types of notation for the same hymn, but both types can appear in association with different hymns. The presence of both textless marginal notation and interlinear syllabic notation in hymnaries suggests a variety of purposes underlying the different approaches used by notators. In hymnaries, diverse methods of notation can appear on the same page. For example, in two eleventh-century hymnaries from the abbey of Farfa, interlinear notation is juxtaposed with the textless marginal notation at the bottom of the page (these manuscripts are discussed further below). For one example, see Figure 4 (Farfa, Biblioteca del Monumento Nazionale, MS A.209, fol. 159). In a hymnary produced at Farfa around 1100 (Rome, Biblioteca

95. I am grateful to Lila Collamore for bringing to my attention the textless marginal notation in Paris, BNF, MS lat. 1085 (fols. 16v, 35r, 36r, 53r, 69v, and 76r).

96. Andreas Haug, "Zum Wechselspiel von Schrift und Gedächtnis im Zeitalter der Neumen," in International Musicological Society Study Group Cantus Planus: Papers Read at the Third Meeting, Tihány, Hungary, 19-24 September 1988, ed. László Dobszay et al. (Budapest: Hungarian Academy of Sciences, 1990), 33-47; and Lori Kruckenberg, "Sequenz," in Die Musik in Geschichte und Gegenwart, 2d rev. ed., ed. Ludwig Finscher (Kassel: Bärenreiter, 1998), Sachteil, vol. 8, cols. 1272-74. 


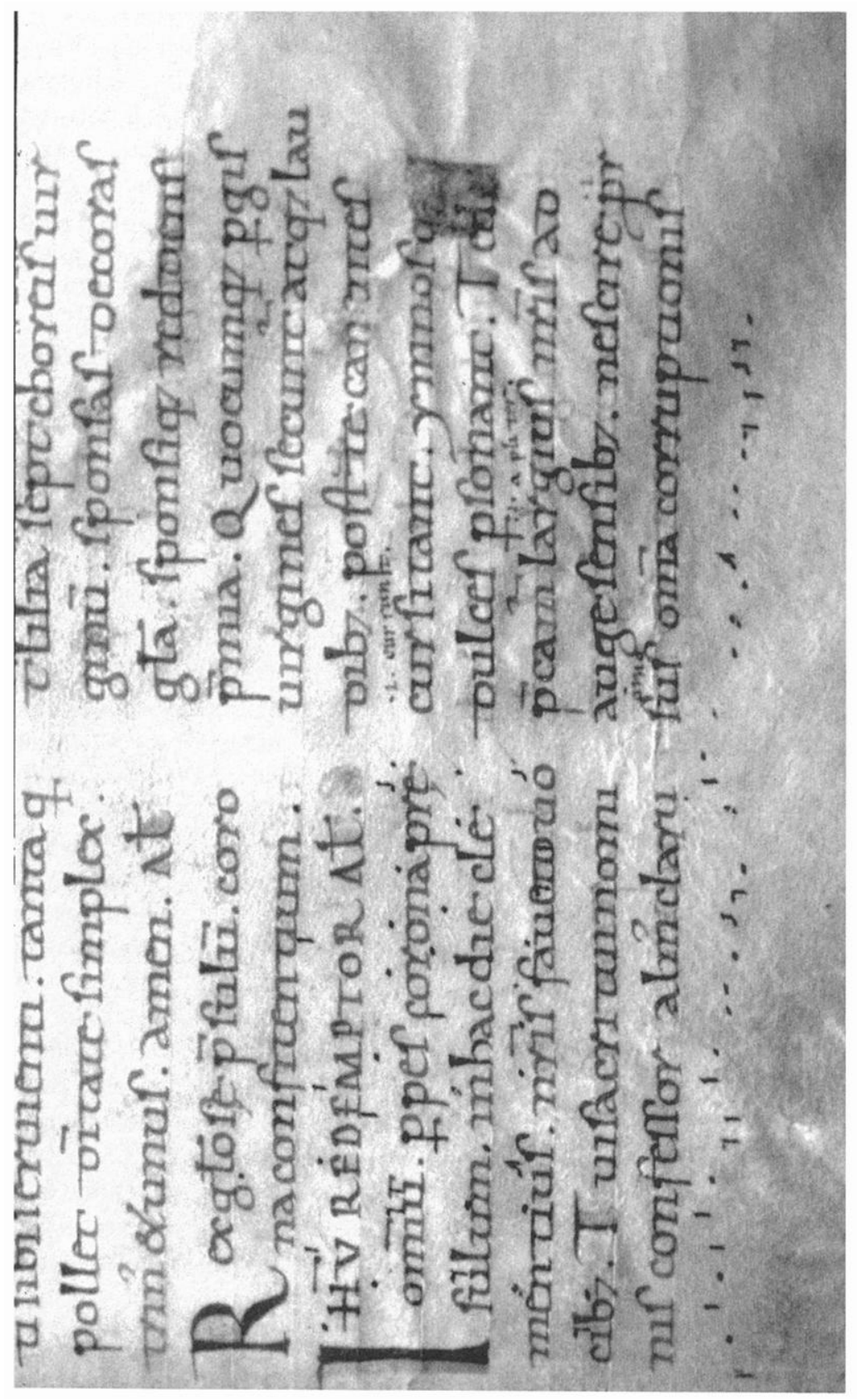

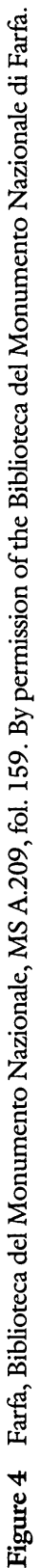


Nazionale, Farfa 4), only three hymns are notated, with melodies added perpendicular to the texts by a slightly later hand.

To summarize, the first systematic notation of hymns took place in the later eleventh century and employed a variety of notational techniques and approaches. While the hymns remained a predominantly oral tradition, notation apparently functioned as an explanation and reinforcement of the oral tradition. This phenomenon can be observed in manuscripts from most of western Europe. Why do early hymnaries exhibit such a diversity of notational practices? Considering the broader historical context of these manuscripts illuminates their function, enabling us to locate them within the framework of orality and literacy generally, and more specifically in relation to contemporaneous developments in monastic culture.

\section{The Historical Context of Early Hymn Notation}

The eleventh century, the earliest period from which great numbers of hymnaries survive, saw multiple waves of monastic reform in much of western Europe and England. ${ }^{97}$ Among the material manifestations of these diverse reforms was the production of customaries, which are detailed records of an abbey's customs, including its liturgy, the duties of monastic officials, and the routine of daily life in the community. Customaries functioned as central texts that defined the character of a given abbey and its affiliates, and they were usually compiled for the benefit of other monasteries interested in imitating or at least investigating the reformed practices of the abbey in question. The compilation of customaries was part of the eleventh-century Zeitgeist that also manifested itself in the building of churches and the production of liturgical manuscripts. As Joachim Wollasch has shown, new customaries were written down at particularly significant moments of change in monastic reform movements. 98

\section{Monastic reform}

The central role of writing and literacy in monastic reform, particularly with regard to the production of customaries, is vividly illustrated by the history of Cluny, the Burgundian abbey whose customs were the most renowned in eleventh-century western Europe. The diffusion of Cluny's customs in the eleventh and twelfth centuries was simultaneous with the development of

97. For overviews of monastic reforms in the central Middle Ages, see Giles Constable, The Reformation of the Twelfth Century (Cambridge and New York: Cambridge University Press, 1996); and Dominique Iogna-Prat, Ordonner et exclure: Cluny et la société chrétienne face à l'hérésie, au judaisme et à l'islam, 1000-1150 (Paris: Aubier, 1998).

98. Joachim Wollasch, "Reformmönchtum und Schriftlichkeit," Frühmittelalterliche Studien 26 (1992): 274-86. 
the Cluniacensis ecclesia, a vast international network of dependencies. ${ }^{99}$ The precise extent of Cluny's influence on these monasteries remained variable until the formation of a truly centralized ordo Cluniacensis in the thirteenth century. ${ }^{100}$ In the eleventh and twelfth centuries, the presence of a Cluniac customary in a monastery signaled an interest in Cluny as a model community, without implying juridical dependence on the abbey. In fact, almost all the manuscripts of Cluny's customs that survive from this period are from monasteries outside the Cluniacensis ecclesia. ${ }^{101}$

The copying of Cluny's customs by so many monasteries in the eleventh and twelfth centuries reflected the renown of the abbey's fabled way of life, which, in addition to its salvific power through intercessory prayer for the dead, was thought by some to transform monks into angels. ${ }^{102}$ The training of oblates at Cluny in the tenth and eleventh centuries aimed to instill in them the purity that would enable them to lead a celestial life on earth and ultimately gain access to paradise. In pursuit of this ideal, ever more adult postulants arrived at the abbey gates in the second half of the eleventh century, and it was probably their growing number that provided the catalyst for recording the customs. Until the middle of the eleventh century, Cluny did not enforce the separation of adult novices from the monks of the community. Once the novices began to reside in separate quarters, however, the ways in which they became integrated into the community changed. ${ }^{103}$ With far more adult

99. Some major accounts of Cluny's history and role are Barbara Rosenwein, Rhinoceros Bound: Cluny in the Tenth Century (Philadelphia: University of Pennsylvania Press, 1982); Joachim Wollasch, Cluny- "Licht der Welt": Aufstieg und Niedergang der klösterlichen Gemeinschaft (Zurich: Artemis und Winkler, 1996); Iogna-Prat, Ordonner et exclure; and Noreen Hunt, Cluny Under Saint Hugh, 1040-1109 (Notre Dame, Ind.: University of Notre Dame Press, 1968). On the entry of monasteries into the Cluniac congregation, see Dietrich Poeck, Cluniacensis Ecclesia: Der cluniacensische Klosterverband (10.-12. Jahrbundert) (Munich: Wilhelm Fink, 1998).

100. On Cluny in the thirteenth century, see especially Florent Cygler, "L'ordre de Cluny et les rebelliones au XIIIe siècle," Francia 19 (1992): 61-93; and Gert Melville, "Cluny après 'Cluny.' Le treizième siècle: Un champ de recherches," Francia 17, no. 1 (1990): 91-124.

101. Burkhardt Tutsch, "Texttradition und Praxis von consuetudines und statuta in der Cluniacensis ecclesia (10.-12. Jahrhundert)," in Vom Kloster zum Klosterverband, ed. Keller and Neiske, 187-88.

102. On intercessory prayer at Cluny, see particularly Dominique Iogna-Prat, "The Dead in the Celestial Bookkeeping of the Cluniac Monks Around the Year 1000," in Debating the Middle Ages, ed. Lester Little and Barbara Rosenwein (Oxford: Blackwell, 1998), 340-62 (translation of "Les morts dans la compatibilité céleste des moines clunisiens autour de l'an Mil," in Religion et culture autour de l'an Mil: Royaume capétien et Lotharingie, ed. Dominique Iogna-Prat and JeanCharles Picard [Paris: Picard, 1990], 55-69). For the angelic nature of monastic life, see IognaPrat, Agni Immaculati: Recherches sur les sources hagiographiques relatives à Saint Maieul de Cluny (954-994) (Paris: Cerf, 1986), 324-34; and Ludo Milis, Angelic Monks and Earthly Men (Woodbridge: Boydell and Brewer, 1992).

103. Isabelle Cochelin, "Peut-on parler de noviciat à Cluny pour les Xe-XIe siècles?" Revue Mabillon 70 (1998): 17-52. 
novices at Cluny than ever before, the traditional oral method of teaching by example was insufficient. In fact, the instruction of adult novices was a relatively new phenomenon in the second half of the eleventh century. In the central Middle Ages, most members of monastic communities grew up within them. Children were given to monasteries at an early age as oblates, and learned the house rules over the course of years by observing and imitating the senior monks. 104

As a result of this system, at Cluny itself the customs remained an oral tradition until the late eleventh century, even as they were being transmitted to other monasteries in writing. ${ }^{105}$ It was the increased presence of adult novices that called for the exceptional decision to write the customs down. In the 1070 s or 1080s, during the abbacy of Hugh I (1049-1106), a monk of Cluny named Bernard wrote down the customs to help the novices learn them, as disagreements arose in daily chapter over their interpretation. ${ }^{106}$ In the same period, Ulrich of Zell also recorded the customs of Cluny at the request of Abbot William of Hirsau, who wished to refer to it as he compiled a customary for his own abbey. Although the texts of Bernard and Ulrich overlap significantly, Bernard's is much more detailed and all-encompassing, and the present study relies primarily upon Bernard's text because it is the only early record of the customs created at Cluny originally for the use of the

104. Isabelle Cochelin, "Besides the Book: Using the Body to Mould the Mind-Cluny in the Tenth and Eleventh Centuries," in Medieval Monastic Education, ed. Ferzoco and Muessig, 21-34.

105. See Isabelle Cochelin, "La singularité de l'oeuvre de Bernard au regard de l'histoire des coutumiers," forthcoming in From Dead of Night to End of Day, ed. Boynton and Cochelin. The oral tradition played a role in the transmission of the written customs to other monasteries, however. Burkhardt Tutsch has shown that in some cases monks from Cluny visited monasteries that had obtained the customs, apparently because the text alone did not provide sufficient information ("Zur Rezeptionsgeschichte der Consuetudines Bernards und Ulrichs von Cluny," in Schriftlichkeit und Lebenspraxis im Mittelalter: Erfassen, Bewahren, Verändern, ed. Hagen Keller, Christel Meier, and Thomas Scharff [Munich: Wilhelm Fink, 1999], 82-83).

106. To be sure, orality continued to predominate well after this period. For instance, the author of the preface to the customary from the Benedictine abbey of Bury St Edmunds, writing in the early thirteenth century, apparently refers to oral sources when he states that "we speak of those things which we know and have learned, and we bear witness to those which we have seen and heard" (Antonia Gransden, ed., The Customary of the Benedictine Abbey of Bury St Edmunds in Suffolk from Harleian Ms. 1005 in the British Museum [Chichester: Morre and Tillyer, 1973], 1: "quae scimus et didicimus constanter loquimur, et quae vidimus et audivimus veraciter testamur"). It was the resolution of internal conflicts between the community and Abbot Hugh de Northwold (1213-15), and the subjection of Bury to visitation after the Fourth Lateran Council, that caused the abbey's customs to be recorded (ibid., xxix). As Gransden points out, the author of the customary notes several differences of opinion about the customs, a sign of the ongoing oral tradition, on page 5, lines 19-34 ("Quidam enim dicunt . . . Alii dicunt . . Tertii vero . ..") and page 28 , lines 36-40 ("volunt quidam . . . Alii vero dicunt . . . Tercii vero . . . habent"). I am grateful to Antonia Gransden for bringing to my attention the role of oral tradition in the Bury customary. 
community itself. ${ }^{107}$ According to Bernard, the novices were leaving chapter more befuddled than when they arrived. ${ }^{108}$ The rules of life at Cluny were far too complex and too numerous to teach orally to newcomers in a hurry. Bernard's customary, which comprises hundreds of pages on every conceivable aspect of daily life, supported but did not supplant an oral tradition that was increasingly unwieldy. ${ }^{109}$ It was during the same period that the community's historiographic activities reached their apex with the redaction of several cartularies and the expansion of hagiographic texts. The multifarious recording of Cluniac history in this period resulted in the morass of documentation that Dominique Iogna-Prat has called the "organization of Cluniac memory."110

The recording of Cluny's customs is analogous to the notation of hymn melodies in the same period: the written record supported and reinforced an expanded oral tradition, and also provided a reference for teaching. In neither case did the written document replace the oral tradition. Monks still learned the customs primarily by observation, ${ }^{111}$ and they continued to learn chant primarily by imitating their teacher's singing, as noted in Ulrich's customary. ${ }^{112}$

The analogy between hymnaries and customaries can be illustrated by the case of the imperial abbey of Farfa, reformed around 998 by Abbot William of Volpiano and Abbot Odilo of Cluny. Farfa never became juridically dependent

107. A thorough account of historians' theories on the dating of these texts is outside the scope of this article, but their relative chronology is a subject of debate. Burkhardt Tutsch argues that the customaries of Ulrich and Bernard are contemporary texts based on the same source (Vorlage). See his "Die Rezeptionsgeschichte der Consuetudines Bernhards und Ulrichs von Cluny im Spiegel ihrer handschriftlichen Überlieferung," Frübmittelalterliche Studien 30 (1996): 248-93; idem, Studien zur Rezeptionsgeschichte der Consuetudines Ulrichs pon Cluny (Münster: LIT Verlag, 1998); and idem, "Zur Rezeptionsgeschichte," 80-81.

108. Bernard, "Ordo cluniacensis," 134; Paris, BNF, MS lat. 13875, fol. 6r: "quaedam de consuetudinibus sepissime oriebantur controuersiae diuersis diuersa sentientibus, ita ut plerumque nouitii hec audientes incertiores de capitulo discederent quam accessissent" ("Certain controversies were arising very often concerning the customs, as different people were understanding different things, so that very many novices, hearing these things, were leaving chapter more uncertain than when they had arrived).

109. Since novices from dependencies of Cluny spent time at the mother house for their monastic profession, the oral transmission of the customs through observation and imitation was an ongoing practice.

110. Dominique Iogna-Prat, "La geste des origines dans l'historiographie clunisienne des XIe-XIIe siècles," Revue bénédictine 102 (1992): 125-91.

111. As Gert Melville points out in "From the Cluny of 'Consuetudines' to the Cluny of 'Statuta,'" the Cluniac customs were validated through actions which were then recorded as texts in the form of the eleventh-century customaries. The fact that the locus of authority remained in actions rather than in texts distinguishes the eleventh-century customaries from the twelfthcentury statutes of Peter the Venerable, where the authority lay in the written records of accrued innovations.

112. Ulrich of Zell, Antiquiores consuetudines monasterii Cluniacensis, in Patrologiae cursus completus, ed. J.-P. Migne, vol. 149 (Paris: Migne, 1853), col. 687. 
on Cluny, but remained loosely connected to the Burgundian abbey. In the years 1050-60, a major building campaign culminated in the rededication of the abbey church by Pope Nicholas II, signaling a cultural and economic golden age that fostered the production of numerous manuscripts, including a Cluniac customary and several liturgical books. The customary, which was written down at Farfa in the years around 1060, was compiled over decades in several stages that illustrate the symbiotic relationship between oral and written transmission in this period. 113 Before Bernard and Ulrich wrote down the customs of Cluny in the 1080s, the only way to learn the details of life at Cluny was to observe it directly; consequently, according to the prologue to the customs of Farfa, a monk named John went to Cluny to observe the customs and write them down for others to read. ${ }^{114}$ In between John's visit to Cluny and the production at Farfa of the earliest manuscript of this customary, Abbot Hugo of Farfa also spent time at Cluny (ca. 1027-32). A monk from Cluny named Martin was in residence at Farfa in the 1050s when the customary was being compiled. 115 Thus the recording of Cluny's customs at Farfa entailed observation and direct personal contact between members of the two communities.

A book for the Divine Office produced at Farfa in the same period as the customary, 1050-60, also illustrates the process of recording another oral tradition: hymn melodies (Vatican City, BAV, MS Chigi C.VI.177). Several different hands added melodies to the manuscript, but the variety of approaches employed suggests a limited need for notation. A comparison of the Chigi hymnary with a psalter-hymnary produced at the abbey at the end of the eleventh century (Farfa, Biblioteca del Monumento Nazionale, MS A.209) reveals a contrast between the informal, sporadic notation of hymns and a more systematic approach.

The differences between these books illustrate the varying intentions of notators and the changes that took place in the second half of the eleventh century. The format of the hymns within these manuscripts does not allow for musical notation, but melodies were added soon after the texts were copied. While the two manuscripts contain roughly the same number of hymn melodies, they are dissimilar in both the notational methods employed and the hymns selected for notation. Several hands with differing purposes and approaches notated the Chigi hymnary (see Table 2 ). A single hand notated

113. Paola Supino Martini dates the earliest manuscript (Vatican City, BAV, MS Vat. lat. 6808 ) to circa 1050-87, probably in the earlier part of that period; see her Roma e l'area grafica romanesca (secoli $X-X I I)$ (Alessandria: Edizioni dell'Orso, 1987), 248.

114. "[A]d uidendum et scribendum properauit apud eundem Cluniacensem caenobium. Et ita exarauit in paginulis ut oculis uidit et in codicibus affixit posterisque legenda contradidit" (Peter Dinter, ed., Liber tramitis aeui Odilonis abbatis [Siegburg: Franz Schmitt, 1980], 4).

115. Joachim Wollasch, "Zur Datierung des Liber tramitis aus Farfa anhand von Personen und Personengruppen," in Person und Gemeinschaft im Mittelalter: Karl Schmid zum fünfundsechzigsten Geburtstag, ed. Gerd Althoff, Dieter Geuenich, Otto Gerhard Oexle, and Joachim Wollasch (Sigmaringen: Jan Thorbecke, 1988), 237-55. 
all but one of the melodies in Farfa A.209, showing one person's systematic approach to the repertory (see Table 3). Almost half the melodies in the Chigi hymnary are added in the margins below their texts. In Farfa A.209, by contrast, only two out of thirteen melodies are notated in the margins. Two strophes of the melody for "Agnetis festum" are notated in the lower margin with a C clef. A single strophe of "Iesu redemptor" is notated both in the margins and between the lines, combining information on pitch content with text-music linkage (see Fig. 4 above). These examples constitute exceptions in the abbey hymnary.

Comparing the notation of the first hymn in each manuscript underlines the contrast between the books. The lack of notation in the Chigi manuscript for "Primo dierum omnium," the hymn for Matins on Sunday in the winter, represents the most common approach to hymns in the eleventh century; one of the best-known hymns, "Primo dierum" was usually not notated. In Farfa A.209, however, neumes were added between the lines of the first strophe of this same text, with an F clef, creating a precise record of the melody's contour. The next hymn in the same manuscript, "Aeterne rerum conditor," is notated by the same hand in its entirety, but without a clef or staff line; the purpose of the notation seems to be to demonstrate text placement but not the contour or pitch content. This inconsistency is common in Farfa A.209; on some pages the notator used clefs for one hymn but not others, and on other pages a single hymn is notated in full, while others are notated only partially.

In the Chigi hymnary, all but two of the notated melodies are for feasts and thus were sung only once a year. Several of the texts selected for notation are demonstrably unusual: numbers 1-2 are rare Italian hymns for Saint Victoria, while numbers 12-13 are recent compositions by Peter Damian. In Farfa A.209, six of the fifteen melodies notated were among the most frequently sung of all: the first two are for the daily Office, and the last four are for the common of saints. This notation of particularly well known chants in the abbey hymnary could be a sign of deterioration in the oral tradition, or perhaps of change in the melodic repertory. Many of these melodies have no clef or custos, however, so that the notation indicates text placement but not precise pitches or details of contour. This is written transmission that complements but does not replace the oral tradition. The visual representation of the melodies could clarify aspects of the text-music relationship in cases of doubt, and would offer a reminder to the cantor who used the book for reference and teaching, but singers still had to learn the melodies essentially without reliance on their written form.

Farfa A.209 was produced at the end of the eleventh century, when the community at Farfa faced increasing challenges in the shifting political terrain of central Italy. It was in this period that the monk Gregory of Catino copied a cartulary presenting the abbey's claims to its territorial rights, precisely the same sort of "organization of memory" that had taken place at Cluny 


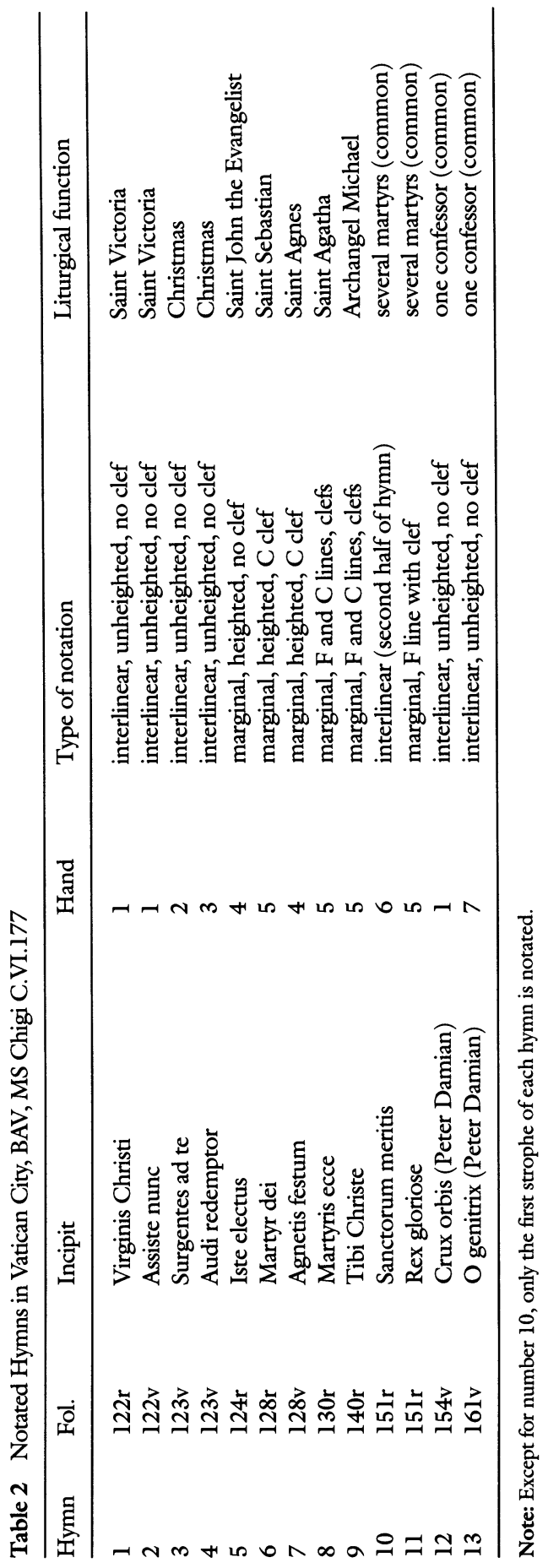




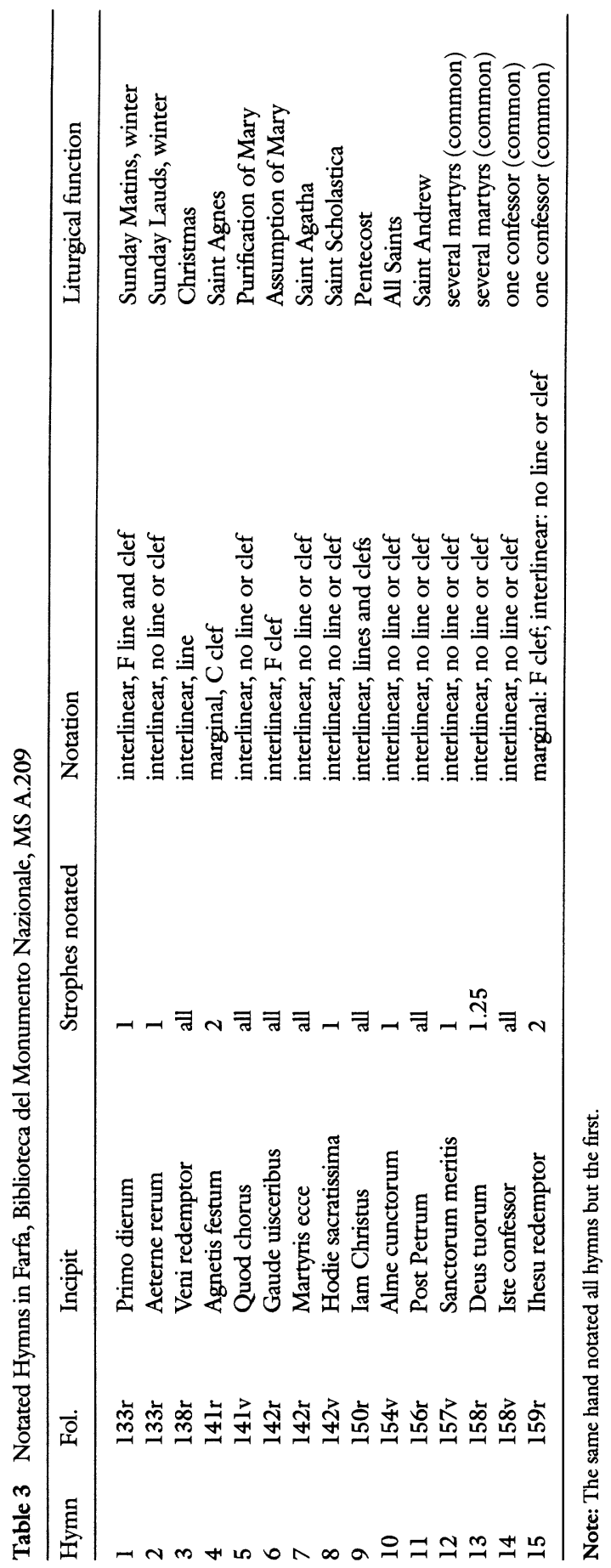


half a century earlier. The recording of memory at both Cluny and Farfa fits into a broader context in which the production of texts constituted the response of monastic historians to their communities' disputes with secular and ecclesiastical authorities. Gregory's archival activity was motivated by his conviction that the abbey's patrimony was threatened. ${ }^{116}$ During the abbacy of Berardus II, who until his sudden death in 1099 was on the road to dispersing the hard-won gains of his predecessor Berardus I (1047-89), Gregory compiled the cartulary known as the Farfa Register by copying thousands of the abbey's archival documents in chronological order. ${ }^{117}$ Gregory's chronicle of the abbey, written between about 1107 and 1119, was the first work of its kind in Italy to employ a hybrid form reproducing the archival documents within a narrative framework, blending the voice of the author with the abbey's traditions. Like other chroniclers of the eleventh and twelfth centuries, Gregory draws upon both oral and written sources, and many narrative passages in his chronicle supply information apparently based on collective memory. ${ }^{118}$ Just as the abbey hymnary differs from the Chigi hymnary with regard to the melodies selected for notation, Gregory of Catino's archival activities reflect new priorities for the ordering of monastic memory. Like the hymnary, Gregory's works supported the oral tradition without replacing it, while creating a new paradigm for the character and the functions of written records.

\section{Consolidation or crisis of the oral tradition?}

This study has emphasized the continued roles of the oral tradition and memory in both the notational and the didactic traditions of the hymns. But the increasing notation of hymn melodies in the later eleventh century suggests

116. Similarly, the twelfth-century chronicle-cartulary from San Clemente at Casauria reflects an intention to reclaim Carolingian holdings lost by the abbey; see Laurent Feller, "Le cartulairechronique de San Clemente a Casauria," in Les cartulaires: Actes de la table ronde organisée par l'École nationale des chartes et le G.D.R 121 du C.N.R.S (Paris, 5-7 septembre 1991), ed. Olivier Guyotjeannin, Laurent Morelle, and Michel Parisse (Paris: École nationale des chartes, 1993), 261-77.

117. He subsequently made other collections of Farfa's archival documents. On Gregory's works, the classic study is Ignazio Giorgi, "Il regesto di Farfa e le altre opere di Gregorio di Catino," Archivio della reale società romana di storia patria 2 (1879): 409-73.

118. On oral and written traditions in the historiography of the eleventh and twelfth centuries, see particularly Richard Emms, "The Historical Traditions of St Augustine's Abbey, Canterbury," in Canterbury and the Norman Conquest, ed. Richard Eales and Richard Sharpe (London: Hambledon Press, 1995): 159-68; Elisabeth van Houts, Memory and Gender in Medieval Europe, 900-1200 (Toronto and Buffalo: University of Toronto Press, 1999); Leah Shopkow, History and Community: Norman Historical Writing in the Eleventh and Twelfth Centuries (Washington, D.C.: Catholic University of America, 1997), 194-95; and John Ward, "The Monastic Historiographical Impulse, c. 1000-1260: A Re-assessment," in Historia: The Concept and Genres in the Middle Ages, ed. Tuomas M. S. Lehtonen and Päivi Mehtonen (Helsinki: Societas Scientiarum Fennica, 2000), 71-100. I am grateful to Professor Emms for sending me his article, and to Professor Ward for giving me a copy of his article before its publication. 
that the oral tradition was beginning to fade. This development is a particular manifestation of the general trend seen in this period toward notation of entire chant repertories. Hymnaries that contain complete notation for all strophes of every hymn attest to the need to codify and record an entire hymn repertory in the utmost detail. The earliest known manuscripts of this kind that have survived were created in the second half of the eleventh century. In the most extensively notated Italian hymnary from before 1100 (Verona, Biblioteca Capitolare, MS CIX [102]), all the strophes of each hymn are notated, even though there are few discernible variants between strophes. The copying and notation of the manuscript were carried out by several different hands at the Benedictine monastery of San Zeno at Verona in the second half of the eleventh century. ${ }^{119}$ In the context of monastic archival activity in the Italian peninsula during the eleventh century, often in response to encroachments by local ecclesiastical authorities, the record of San Zeno's hymn repertory in this manuscript could be seen as one element of a more general consolidation of traditions in the face of the cathedral's increasing centralization of power around the bishop. ${ }^{120}$ Other eleventh-century manuscripts in which all strophes of all the hymns are notated can also be interpreted as records of a monastery's traditions. The late eleventh-century hymnary contained in Benevento 37, from Santa Sofia in Benevento, was produced during a period of expansion in which the abbey undertook building campaigns and maintained a flourishing scriptorium..$^{121}$ In addition to the hymnary, Benevento 37 comprises a typical collection of monastic texts, such as a collection of readings for chapter (fols. 59-158) that includes litanies, a martyrology, a necrology, and the Benedictine Rule. ${ }^{122}$ The Huesca hymnary (discussed above) fur-

119. On this manuscript, see I codici liturgici della Cattedrale di Verona (Verona: Biblioteca Capitolare, 1987), 106-7; Antonio Spagnolo, I manoscritti della Biblioteca Capitolare di Verona, ed. Silvia Marchi (Verona: Casa Editrice Mazziana, 1996), 196-99; Réginald Grégoire, "Repertorium liturgicum italicum," Studi medievali, n.s. 9 (1968): 578; and James Borders, "The Cathedral of Verona as a Musical Center in the Middle Ages: Its History, Manuscripts, and Liturgical Practice" (Ph.D. diss., University of Chicago, 1983), 253-61 and 462-65. I thank Professor Borders for sending me these pages from his dissertation.

120. On the relationship between the abbey of San Zeno and the bishop and canons of Verona, see Maureen Miller, The Formation of a Medieval Church: Ecclesiastical Change in Verona, 950-1150 (Ithaca, N.Y., and London: Cornell University Press, 1993), 123-27.

121. This period in the history of Santa Sofia is described in Thomas Forrest Kelly, ed., $L a$ cathédrale de Bénépent (Ghent and Amsterdam: Ludion, 1999), 51, 164. For a complete description of the manuscript, see Mallet and Thibaut, Les manuscrits en écriture bénéventaine 1:193-235. The entirety of the hymnary is fully notated (fols. 19r-58v) except for a gathering that was apparently lost and replaced with unnotated texts (fols. 47-52).

122. The hymns were often transmitted with the Benedictine Rule and other texts pertaining to the monastic life. Another example is a ninth-century book from San Colombano of Bobbio (Turin, Biblioteca Nazionale, MS G.V.38) that contains the Rules of Benedict and Columban, a hymnary, the canons of the Council of Aachen in 817, and the Sermons or Instructions of Saint Columban; see Jullien, "Les sources," 95 . The Rule is transmitted along with a hymnary in Trier, Stadtbibliothek, MS 1245/597; Turin, Biblioteca Nazionale, MS G.VII.18; and Zurich, Zentralbibliothek, MS Rheinau 111, among others (Jullien, "Les sources," 94-95, 102-4). 
nishes another example of an apparent need to supply all possible combinations of text and melody, perhaps because it was replacing a native oral tradition with a new hymn repertory.

The notating of entire hymnaries at important historical moments seen in the Verona, Benevento, and Huesca hymnaries is also found in an early twelfth-century manuscript from Nevers (fols. 147v-177v of Paris, BNF, MS n.a.l. 1235). The hymnary contains complete staff notation for all its texts; ${ }^{123}$ many melodies are notated in full for all the texts to which they are sung. Since there are almost no variants between the strophes of individual hymns or between the melodies that are sung to multiple texts, one might ask why the notator went to considerable effort to add neumes to every strophe of every hymn. The seeming superfluity of these repetitions may indicate that the manuscript had an important archival function. It is one of two liturgical books (Paris, BNF, MS n.a.l. 1235 and MS n.a.l. 1236) containing chants for the Mass and the Office in the Cathedral of St. Cyr in Nevers. When these books were produced in the early twelfth century, the hymns may have been new elements in the cathedral Office at Nevers, in which case it would be useful to show explicitly in writing the structure of individual hymns and of the hymn repertory as a whole. In the absence of a preexisting oral tradition, wholesale written transmission of the hymns would have to stand in for the oral processes by which singers usually assimilated them. Such a theory (and it must remain a theory) would explain why the book seems designed to demonstrate so exhaustively its system of repertorial organization. As Margot Fassler has pointed out, the Nevers manuscripts represent a moment of transition for the cathedral more generally, and particularly for notational innovation: the sequence and trope repertory has been transferred from the unheighted neumes of earlier manuscripts from Nevers to a new notational system with colored staff lines. ${ }^{124}$

Another way of viewing the increasing reliance on notation for the hymn repertory in the eleventh and twelfth centuries is to examine manuscripts that were neumed by several different hands over a long period of time. The eleventh-century hymnary from Kempten (Zurich, Zentralbibliothek, MS Rheinau 83) illustrates this point; the neumes were added by several different hands ranging in date from the mid-eleventh to the mid-twelfth century (see Table 4). In addition to adiastematic German neumes, several hymns have letter notation above the text of the first strophe only; in a few cases the letter notation was added subsequently to hymns that were already neumed, while in others the letter notation preceded the neumes. While the letter notation accompanies only one strophe of a hymn, in many cases neumes were added to multiple strophes, implying that complete neumation was useful to the user of the manuscript, even though the pitch content of the melody was already specified in the notation of the first strophe. The neumation seems to indicate

123. The melodies in this manuscript were edited by Stäblein in Hymnen, 70-108.

124. Fassler, Gotbic Song, 101. 
many minor melodic variants between the strophes of individual hymns, but letter notation that would have specified the pitch content of these melodic alterations was never added. Varying amounts of text were neumed, ranging from half a strophe to the entire text. Bruno Stäblein, who edited the melodies transmitted in letter notation, attributed Rheinau 83 to the early eleventh century and treated the manuscript as a more or less unified musical text. ${ }^{125}$ The multiple layers of notation, however, show the multilayered character of the document, illuminating the shifting roles of oral and written transmission over several decades. Many layers of notation are also visible in Munich, Bayerische Staatsbibliothek, MS lat. 17027, an Office book containing a hymnary copied around 1000-1020, probably in Freising, for the abbey of Schäftlarn. ${ }^{126}$ Neumes were added to the hymnary by eleven different hands of the eleventh and twelfth centuries, providing the melody for a single strophe, multiple strophes, or all strophes of a hymn. Although the hymnary was not originally intended to be notated, users of the manuscript saw a need for musical notation, showing the increased use of writing for the preservation of hymn melodies.

The fact that many hymnaries that were not originally designed for notation were nevertheless neumed during the eleventh and twelfth centuries also supports the thesis of an increasing reliance on notation and thus a transition from oral to written transmission. A ninth-century manuscript from the abbey of Bobbio (Turin, Bibioteca Nazionale, MS G.VII.18) provides a striking example of the adaptation of liturgical books over time. ${ }^{127}$ Seven of the hymns were notated during the eleventh century by a total of eight different hands. "Ut queant laxis" (fol. 99r), which was a tenth-century addition to the manuscript, was later notated by two different hands. Another manuscript from Bobbio (Vatican City, BAV, MS Vat. lat. 5776), an eleventh-century hymnary that was clearly not designed for notation, nevertheless exhibits a bewildering array of notational hands, which added diastematic neumes roughly contemporary with the text. ${ }^{128}$ Some hymns have only partial notation; isolated melismas are added here and there within a strophe, apparently to clarify text placement and to indicate variants between strophes. ${ }^{129}$ As stated above, such partial notation serves to highlight passages that may have been thought to

125. Stäblein's critical report focuses primarily on the date of the manuscript and on the pitch content of the melodies, with some commentary on the notation (Hymnen, 578-81).

126. Natalia Daniel, Handscbriften des zebnten Jabrbunderts aus der Freisinger Dombibliothek (Munich: Arbeo-Gesellschaft, 1973), 98; Hartmut Hoffmann, Bucbkunst und Königtum im ottonischen und frühsalischen Reich (Stuttgart: Hiersemann, 1986), 1:418-20; Klaus Gamber, Codices liturgici Latini antiquiores: Supplementum (Freiburg: Universitätsverlag, 1988), 146; and Jullien, "Les sources," 124-25.

127. On this manuscript, see Jullien, "Les sources," 94-95.

128. On this manuscript, see ibid., 114-15. The ink of many neumes is so faded that they are hardly visible, even under ultraviolet light.

129. For instance, neumes are added sporadically to "O pater alme mitis" (fol. 74r) and to only the second half of strophes 2-7 in "Aue maris stella" (fols. 86v-87r). 
Table 4 Inventory of Hymns in Zurich, Zentralbibliothek, MS Rheinau 83

\begin{tabular}{|c|c|c|c|}
\hline Page & Text & Function & Amount/type of notation \\
\hline 37 & Primo dierum omnium & Sunday Matins in winter & strophe 1 : letter notation \\
\hline 38 & Nocte surgentes & Sunday Matins in summer & strophe 1 : letter notation \\
\hline 38 & Ecce iam noctis & Sunday Lauds in summer & strophe 1 : letter notation \\
\hline 38 & Aeterne rerum & Sunday Lauds in winter & strophe l: letter notation \\
\hline 40 & Rector potens & Sext & strophe 1 : neumes \\
\hline 40 & Lucis creator optime & Sunday Vespers & $\begin{array}{l}\text { strophe } 1 \text { : letter notation and } \\
\text { neumes; others: neumes }\end{array}$ \\
\hline 41 & O lux beata trinitas & Vespers & $\begin{array}{l}\text { strophe } 1 \text { : letter notation } \\
\text { and neumes; strophe } 2 \text { and } \\
\text { doxology: neumes }\end{array}$ \\
\hline 41 & Somno refectis & Monday Matins & strophe 1 : letter notation \\
\hline 42 & Splendor paterne & Monday Lauds & strophe 1 : letter notation \\
\hline 43 & Immense caeli & Monday Vespers & strophe 1 : letter notation \\
\hline 43 & Consors paterni & Tuesday Matins & strophe 1 : letter notation \\
\hline 50 & Te lucis ante & Compline in summer & strophe 1 : letter notation \\
\hline 50 & Christe qui lux es & Compline in winter & strophe 1 : letter notation \\
\hline 51 & Conditor alme & Advent Vespers & $\begin{array}{l}\text { strophe } 1 \text { : letter notation and } \\
\text { neumes; others: neumes }\end{array}$ \\
\hline 52 & Agnoscat omne & Christmas & $\begin{array}{l}\text { incipit: neumes; strophe 1: } \\
\text { added letter notation }\end{array}$ \\
\hline 53 & Sollemnis dies aduenit & John the Evangelist & $\begin{array}{l}\text { strophe } 1 \text { : letter notation and } \\
\text { neumes; others: neumes }\end{array}$ \\
\hline 54 & Hostis Herodes & Epiphany & strophe 1 : letter notation \\
\hline 55 & Ihesus refulsit & Epiphany & $\begin{array}{l}\text { strophe } 1 \text { : letter notation; } \\
\text { strophes 1-2: added neumes }\end{array}$ \\
\hline 56 & Quod chorus uatum & Purification & $\begin{array}{l}\text { strophes 1-4: added neumes; } \\
\text { strophe l: added letter notation }\end{array}$ \\
\hline 56 & Vexilla regis & Good Friday & strophe l: letter notation \\
\hline 57 & Signum crucis mirabile & Holy Cross & strophes 1-2: neumes \\
\hline $57-58$ & Vita sanctorum Deus & Easter & $\begin{array}{l}\text { strophe } 1 \text { : letter notation, } \\
\text { neumes; strophes } 2-3 \text { : } \\
\text { neumes }\end{array}$ \\
\hline 61 & Beata nobis gaudia & Pentecost & strophe 1 : letter notation \\
\hline 62 & Ut queant laxis & John the Baptist & $\begin{array}{l}\text { strophes } 1-2,3 \text {, first half } \\
\text { of } 5 \text {, and the word prebuit } \\
\text { (str. 6): added neumes }\end{array}$ \\
\hline 63 & O nimis felix & John the Baptist & strophe 1 : letter notation \\
\hline $63-64$ & Aurea luce & Peter and Paul & all strophes: later neumes \\
\hline $64-65$ & Martyris Christi colimus & Lawrence & text on p. 65 : added neumes \\
\hline $68-69$ & Veni redemptor gentium & Advent & all strophes: added neumes \\
\hline 70 & Christe redemptor & Christmas & strophe 1 : added neumes \\
\hline 70 & A solis ortus & Christmas & all strophes: added neumes \\
\hline 71 & Stephano primo martyri & Stephen & strophe 1 : added neumes \\
\hline 75 & Quem terra pontus & Purification & all strophes: added neumes \\
\hline $75-76$ & Gaude visceribus & Purification & all strophes: added neumes \\
\hline 79-80 & Ad caenam agni & Easter Vespers & all strophes: added neumes \\
\hline 80 & Te lucis auctor personant & Easter Prime & $\begin{array}{l}\text { strophe } 1, \text { lines } 1-2: \text { added } \\
\text { neumes }\end{array}$ \\
\hline
\end{tabular}


Table 4 continued

\begin{tabular}{|c|c|c|c|}
\hline Page & Text & Function & Amount/type of notation \\
\hline 82 & Festum nunc celebre & Ascension & $\begin{array}{l}\text { strophe l: letter notation; } \\
\text { all strophes: added neumes } \\
\text { in two different hands }\end{array}$ \\
\hline $83-84$ & Veni creator spiritus & Pentecost & $\begin{array}{l}\text { all strophes: neumes; strophe } \\
1: \text { letter notation and } \\
\text { neumes; last strophe: added } \\
\text { neumes }\end{array}$ \\
\hline 84 & Christe sanctorum remeat & Gordian and Epimachus & strophe 1 : later neumes \\
\hline 85 & Almi prophetae & John the Baptist & incipit: later neumes \\
\hline $87-88$ & Alma Christi quando & Maurice & all strophes: neumes \\
\hline $88-89$ & Christe sanctorum & Michael & all strophes: neumes \\
\hline 89 & Vita sanctorum uia & Gall & strophes 1-4: neumes \\
\hline 90 & Christe qui uirtus & All Saints & strophes $1-2$ : added neumes \\
\hline $94-95$ & Sanctorum meritis & confessors & strophes 1-3: added neumes \\
\hline 94 & Martyr Dei qui unicum & one martyr & strophe 1 : added neumes \\
\hline 112 & Deus tuorum militum & martyr & all strophes: added neumes \\
\hline 113 & Ihesu redemptor omnium & confessor & strophe $1:$ neumes \\
\hline 114 & Christe caelorum & dedication & strophes 1-4: added neumes \\
\hline
\end{tabular}

need particular emphasis when teaching the hymn. Similarly, in a hymnary that forms part of a manuscript copied in Saxony around 1100 (Zurich, Zentralbibliothek, MS Rheinau 97), ${ }^{130}$ the amount of text notated ranges from a single syllable to an entire hymn (see Table 5). Some of the neumes are contemporaneous with the text, while others are somewhat later. There is no discernible correspondence between the apparent date of a notational hand and the amount of text that it notated; the approaches to notation in this manuscript are as numerous as the notators. To mention just two examples, one hand notated only the first and last strophes of "O quam glorifica luce" (p. 191), while in most other hymns, the notated strophes are sequential. Notators added contrasting melodies to the first and last strophes of "Splendor paterne gloriae."

Beginning in the twelfth century, the format of hymn manuscripts allowed more often for consistent notation of all the hymns in precisely the same manner. This development is presaged by a hymnary copied around 1100 at the abbey of Saint-Loup de Troyes (Troyes, Bibliothèque Municipale, MS 571), in which the first strophe or just the incipit of each hymn is notated in French neumes on a four-line staff. ${ }^{131}$ Nevertheless, the continuity of older notational practices is evident in this manuscript: in some cases the notator continued the melody beyond the staff lines, employing staffless neumes so as to complete the notation of the first strophe.

130. See Leo Cunibert Mohlberg, Mittelalterliche Handschriften, part 1 of Katalog der Handschriften der Zentralbibliotbek Zürich (Zurich: Zentralbibliothek, 1932-52), 3:206.

131. Except for "Ex ipsius tumba manat," for Saint Nicholas (fol. 16r). 
Table 5 Notated Hymns in Zurich, Zentralbibliothek, MS Rheinau 97

\begin{tabular}{|c|c|c|c|}
\hline Page & Incipit & Amount of notation & Scribe \\
\hline 131 & O lux beata trinitas & entire hymn & later hand \\
\hline 131 & Nocte surgentes uigilemus omnes & entire hymn & same ink as text \\
\hline 136 & Nunc sancte nobis spiritus & first strophe & later hand \\
\hline 140 & Splendor paterne gloriae & first strophe & same hand as on 136 \\
\hline 141 & Splendor paterne gloriae & last two strophes & later hand \\
\hline 147 & Tu trinitatis unitas & first strophe & later hand \\
\hline 152 & Veni redemptor gentium & first strophe & later hand \\
\hline $165-66$ & Iesu quadragenariae & entire hymn & later hand \\
\hline $166-67$ & Vexilla regis prodeunt & entire hymn & later hand \\
\hline 167 & Auctor salutis & first strophe & later hand \\
\hline $168-69$ & Ad cenam agni & entire hymn & later hand \\
\hline 171 & Vita sanctorum & first two strophes & later hand \\
\hline 175 & Astra polorum & entire hymn & later hand \\
\hline 177 & Beata nobis gaudia & first strophe & later hand \\
\hline 178 & Iam Christus astra & first strophe & later hand \\
\hline 180 & Fit porta Christi peruia & first two strophes & same ink as text \\
\hline 180 & Ave maris stella & first syllable & later hand \\
\hline $189-90$ & Quem terra pontus & first two strophes & later hand \\
\hline 191 & O quam glorifica luce & first and last strophes & later hand \\
\hline 192 & Maria mater Domini & first strophe & later hand \\
\hline $205-6$ & Gaude uisceribus & entire hymn & later hand \\
\hline 207 & Christe caelorum habitator & first strophe & later hand \\
\hline
\end{tabular}

\section{Increasing reliance on writing}

Analysis of hymn sources from the later eleventh and twelfth centuries suggests an increasing reliance on notation for the transmission of hymn melodies, in addition to the oral tradition. The idea that writing was becoming ever more important for the preservation and transmission of hymns during the late eleventh and twelfth centuries finds support in various forms of external textual evidence. In particular, prescriptions in monastic customaries for teaching chant suggest a transition from predominantly oral transmission in the eleventh century to more frequent recourse to books in the twelfth. Eleventh-century customaries tend to describe the training of boy singers as a group activity supplemented by limited individual practice, sometimes using books. ${ }^{132}$ Twelfth-century customaries, which refer to individual study with books, reflect an increasing reliance on literacy, or at least on literate modes of learning. For instance, the customary written around 1100 at the abbey of Fruttuaria, in northern Italy, refers to the use of books during the boys' daily lesson with their teacher. Reliance on books was apparently somewhat discouraged for the youngest of the students: "No one looks at the book there,

132. Boynton, "Training for the Liturgy." 
unless there is a boy so old that he cannot learn otherwise; and if there are two of them, they take a board, put it between them, and place the book on top of it." 133 According to this customary, however, a boy was allowed to practice reading during Mass and was excused from singing with the other boys in order to learn the psalms or hymns. ${ }^{134}$ While these prescriptions describe exceptions made for specific circumstances, the customary seems to assume that oral transmission in a group lesson was still the primary mode of learning chant for boys.

The education of literate adult novices, however, relied heavily on the use and availability of books. The Fruttuaria customary prescribes that literate novices be lent a psalter and a hymnary to keep for up to a year. ${ }^{135}$ Although they had to recite psalms for their teacher, they often studied alone. According to the twelfth-century customary from the Augustinian abbey of St. Victor in Paris, novices were supposed to memorize psalms and hymns as they sat in the cloister. ${ }^{136}$ The librarian (armarius) was responsible for distributing books to those learning the psalms and hymns as well as to all brothers who needed to practice chants for upcoming services. ${ }^{137}$ These contrasts between the education of child oblates and that of adult novices are not surprising; the variety of approaches to teaching and learning seen in the customaries arises from the perceived or presumed differences in literate competence between the two populations.

The increasing reliance on literacy seen in the customaries provides a framework for evidence supplied by other texts of the late eleventh and twelfth centuries that the oral tradition of the hymns was in some disarray. Some of the most striking examples are found in the grammatical treatises known as artes lectoriae and in the statements of Peter Abelard concerning hymns. Although these diverse witnesses cannot be reduced to a single message of decay in the hymn repertory, they put the manuscript evidence in context by articulating the concerns of those who were teaching and singing the hymns.

133. "Nullus ibi aspicit in librum, nisi tam magnus puer sit, qui aliter discere non possit, et si duo sunt, apprehendunt tabulam et inter se ponunt et librum desuper mittunt" (Luchesius Spätling and Peter Dinter, eds., Consuetudines fructuarienses-Sanblasianae [Siegburg: Franz Schmitt, 1987], 2:150-51).

134. Ibid., $1: 21$.

135. "Si est litteratus apprehensa confessione psalterium et ymnarius ei in manum mittitur et usque ad unum annum, si ei necesse est, dimittitur" (ibid., 2:265).

136. "Quando autem in claustro nouitius sedet, debet firmare psalterium suum, et cordetenus ad uerbum reddere, et postea hymnarium" (Luc Jocqué and Ludo Milis, eds., Liber ordinis S. Victoris Parisiensis [Turnhout: Brepols, 1984], 107).

137. "Fratribus, quibus iniunctum est, cantum suum cotidie firmare et reddere, debet armarius singulos libros, in quibus cantant, specialiter assignare. . . Similiter his, qui psalmos et hymnos suos firmare habent, psalteria et hymnarios, prout opus fuerit, distribuat. . . . Debet autem armarius unum antiphonarium uel duos et alios libros de cantu et psalteria et hymnarios in communi proponere, in quibus ceteri fratres possint, quod prouidendum est, prouidere” (ibid., 146). 
Artes lectoriae provide instructions for the pronunciation of liturgical texts along with linguistic analysis of them. The artes lectoriae from the eleventh and twelfth centuries that have been published allude to several cases of incoherence in the hymns' textual traditions, as well as to variants created by oral transmission. ${ }^{138}$ Two closely related texts from the later eleventh century, attributed respectively to Aimericus and Siguinus, contain numerous citations of hymns. ${ }^{139} \mathrm{~A}$ third, anonymous, treatise transmitted in a single twelfth-century manuscript makes even more extensive use of the hymns and has some material in common with the other two texts. ${ }^{140}$ In addition to accentuation and pronunciation, the artes lectoriae address many aspects of morphology and grammar, including the derivation and composition of words, mutation of vowels and consonants, declinations, homonyms, and synonyms. In most cases, hymn texts provide examples of particular forms, classes of nouns or verbs, accentuation patterns, or morphology; they also serve to demonstrate grammatical points. The artes lectoriae show the use of hymns in Latin language instruction, a function also documented by other sources in the medieval grammatical tradition. These treatises manifest a concern with the linguistic and doctrinal correctness of liturgical texts, and refer frequently to textual readings found in liturgical books from various places. Both characteristics strongly suggest that the authors of the treatises were involved in the emendation of their communities' liturgical books. Their allusions to the performance of chant strengthen this hypothesis and imply that Aimericus and Siguinus were among the monastic officials responsible for the education of singers, who usually included the cantor and his assistants. Monastic customaries of the period indicate that one of the duties of cantors was to correct the liturgical books so as to maintain their reliability and theological orthodoxy. ${ }^{141}$ It comes as no surprise, then, that the artes lectoriae illuminate the performance of hymns as well as the pedagogical functions of their texts. The anonymous Ars lectoria gives rules for the use of doxologies, a rare explanation of a practice that seems to have been part of the basic training of singers. Most important for the present study, all the artes discuss textual variants generated (and perpetuated) in performance.

Aimericus and Siguinus identify common textual corruptions that occur when singers misunderstand the meter or grammar of a given verse. Even though both authors admittedly rely on earlier sources, in many cases it seems likely that they are recounting their experiences as teachers hearing incorrectly

138. For further discussion of references to the hymns in the artes lectoriae, see Boynton, "Glossed Hymns," 206-18.

139. Aimericus, Ars lectoria, ed. Harry Reijnders, in Vivarium, vol. 9 (1971): 119-37, and vol. 10 (1972): 41-101, 124-76; and Siguinus, Ars lectoria: Un art de lecture à baute voix du onzième siècle, ed. Joseph Engels, C. H. Kneepkens, and Harry Reijnders (Leiden: Brill, 1979).

140. Vito Sivo, ed., Ars lectoria e codice Parisino Latino 8499 (Bari: Levante, 1990).

141. On the armarius's and cantor's responsibility for correcting liturgical books, see Fassler, "The Office of the Cantor," 42, 46-47. 
pronounced liturgical texts; their comments on the textual errors perpetuated by singers resemble personal tirades and are not part of the material common to the two treatises. ${ }^{142}$ The realistic depiction in the artes lectoriae of the confusion among various singers' renderings of the hymns suggests that some textual variants originated in regional customs and were then preserved in the oral tradition. For instance, when discussing common errors in the performance of "Aeterne rerum conditor," Aimericus explains the difference between a legitimate divergence from the established text and a mistake that contradicts the meaning of the hymn verse:

Concerning these things it must be answered that one thing can be said just as well as another. In this matter each church should follow its own books and customs, lest the choir disagree, singing inconsistently. And thus at that place: "Let us sing that Christ is the prince born from the Virgin Mary" [natum maria uirgine], if anyone will have sung it with the genitive "of the Virgin Mary" [natum Marie uirginis], he will have sung it well in any case. It should just appear that all sing one thing concordantly together in the choir. For in such cases the meaning is not conflicting or different. ${ }^{143}$

This passage is not the only evidence that the variant "natum Marie uirginis" was performed by singers and discussed by commentators. A gloss in an eleventh-century hymnary from the Parisian abbey of St. Germain-des-Prés states that "some say 'natum Marie uirginis' but 'natum Maria uirgine' is fine, and therefore it is not necessary that it be changed." 144 The gloss may reflect a tradition shared by Aimericus's commentary, or perhaps they simply both refer to what must have been a widespread variant.

The same glossed hymnary contains a variant deplored by Aimericus, namely the phrase "hoc excitatus lucifer" in the third strophe of "Aeterne rerum conditor," which refers to cockcrow at dawn. The reading of the first two verses favored by Aimericus is "hoc excitato, lucifer soluit polum caligine" ("the cock having been awakened, the morning star frees the sky of darkness"), but most medieval manuscripts instead have the reading "hoc excitatus lucifer soluit polum caligine" ("the morning star, once awakened by it [the

142. Roger Wright speculated that Aimericus and Siguinus taught in northern Spain in the late eleventh or early twelfth century, in the service of the liturgical reform that introduced new methods of reading Latin texts aloud in the Iberian peninsula (Late Latin and Early Romance in Spain and Carolingian France [Liverpool: Frances Cairns, 1982], 224-26).

143. "Quibus respondendum est, quoniam tam bene hoc quam illud dicitur. In quo ecclesia queque libros suos et usus sequatur, ne chorus discors dissentiat canens. Sic et ibi 'Christum canamus principem natum Maria virgine' et si dixerit aliquis per genitivum 'natum Marie virginis,' bene utique dixerit. Tantum illud videatur, ut simul concordes unum in choro canant omnes. Non enim sententia in talibus diversa est aut alia" (Aimericus, Ars lectoria, 63).

144. 'Quidam dicunt 'natum Marie uirginis,' sed bene stat 'natum Maria uirgine,' et ideo non est necesse ut mutetur" (Paris, BNF, MS lat. 11550, fol. 255r). 
cock], frees the sky of darkness"). ${ }^{145}$ In the continuation of the passage cited above, Aimericus heaps scorn and even accusations of moral turpitude upon those who sing "excitatus" instead of "excitato":

But we warn the wise to correct that which cannot be pronounced in the hymns without a betrayal either of the meaning or of the art of grammar, or even of meter, as where it is said "this one having been awakened, that is, the rooster, the morning star frees the sky of darkness," where fools say "the morning star having been awakened." I call them fools because of [their] ignorance, not because [they are] evil. Nevertheless there are very many whose injustice and deceit did not want to understand. For when those in the world who have power over us observe that we know something above them, they envy and hate us, and they can do nothing with swords, so they persecute us with words. For who could hold back a laugh when they say that the morning star is awakened instead of the rooster? "This morning star is awakened"? Therefore you who wish to understand, sing: "this one having been awakened, the morning star." 146

The glossator of the Parisian hymnary agreed with Aimericus, noting the apparent incongruity of the reading "excitatus" while offering a fanciful explanation for it: "Why does [the verse] lead from the cock to the awakened morning star, which never sleeps? In reply to this [question] one must say that it seems almost to sleep, when we do not see it."147

Both of these examples manifest a teacher's concern with varying performance traditions of well-known hymn texts. Comparable variety in the performance of melodies could have been a factor that would encourage cantors to write them down. Such diversity in the manuscript tradition was aptly characterized by Guido of Arezzo: "In short, scarcely one concords with another,

145. For the listing of variants, see the apparatus in Ambroise de Milan: Hymnes, ed. Jacques Fontaine et al. (Paris: Cerf, 1992), 149.

146. "Illud vero quod sine mendatio vel sententie vel grammatice artis vel etiam metri in ymnis proferri non potest, sapientes ut corrigant admonemus, ut illud ubi dicitur 'hoc excitato,' scilicet gallo, 'Lucifer solvit polum caligine,' ubi stulti 'hoc excitatus Lucifer' dicunt. Stulti dico ad ignorantiam, non ad nequiciam. Sunt tamen perplures quorum iniquitas et dolus noluit intellegere. Cum enim in seculo qui super nos aliquid possunt, scire nos super se aliquid contuentur, invident et oderunt et cum gladiis nequeant, verbis nos insecuntur. Quis enim teneat risum, cum propter gallum excitari dicant Luciferum. 'Hoc excitatus Lucifer'? Tu ergo qui volueris intellegere 'hoc excitato Lucifer' cane" (Aimericus, Ars lectoria, 63; I have added some quotation marks). The author of the anonymous Ars agrees: "Again, not excitatus, which is to be erased and expunged, but rather the ablative excitato should be said there . . . 'once the cock is awakened,' not the morning star awakened on account of the cock" ("Item non 'excitatus,' quod radendum est et expungendum, sed per ablativum 'excitato' dicendum est ibi . . . 'gallo excitato,' non 'excitatus Lucifer' propter gallum”) (Ars lectoria e codice Parisino Latino 8499, ed. Vito Sivo [Bari: Levante, 1990], 87).

147. "[Q]uare ducit a gallo excitatum luciferum, qui numquam dormit? Ad quid dicendum, quia quasi dormire uidetur, quando a nobis non uidetur" (Paris 11550, fol. 244r). 
neither a student with his teacher, nor a student with his fellow students. As a result, now there are not one or even a few antiphoners, but as many antiphoners as there are teachers in the churches."148 Guido's complaint places in context the variants cited by the artes lectoriae and the glosses. All these texts suggest instability in the oral tradition and its effect on the written record.

In the early twelfth century, within decades of the artes lectoriae, Peter Abelard also referred to deficiencies in the performance of hymns. While Abelard's name usually evokes his contributions to scholastic philosophy and his attachment to his erstwhile student Heloise, he was also a composer who strove to fashion an ideal hymn repertory for the abbey of the Paraclete, the Benedictine community he founded for Heloise. ${ }^{149}$ It was at the request of Heloise, then abbess of the Paraclete, that Abelard composed new hymns to compensate for the inadequacies of the standard repertory. In the preface to the first part of his hymn collection, he responded to the problems Heloise had described in the existing hymn repertory. ${ }^{150}$ Many texts were of uncertain authorship, and several feasts of great theological importance lacked their own proper hymns. In the preface to his hymnary for the Paraclete, Abelard referred to Heloise's observations on the inconsistencies in the performance of hymns, including the singing of certain hymns at a time of day that contradicted the one mentioned explicitly in the text. Moreover, according to Heloise the versification of some texts made them difficult to sing: "Frequently, the inequality of syllables is so great that the songs can scarcely receive a melody, without which a hymn can by no means exist."151 This statement may refer to the difficulty of singing a melody to different strophes of text, particularly when their patterns of accentuation and even syllable counts were

148. "Vix denique unus concordat alteri, non magistro discipulus, nec discipulus condiscipulis. Unde factum est ut non iam unum aut saltem pauca sed tam multa sint antiphonaria quam multi sunt per singulas ecclesias magistri" (Guido d'Arezzo, Prologus in antiphonarium, in Guido d'Arezzo's Regule rithmice, Prologus in antiphonarium, and Epistola ad michaebelem, ed. and trans. Dolores Pesce [Ottawa: Institute of Mediaeval Music, 1999], 410-12); translation mine.

149. On Abelard's hymns, see the commentary by Chrysogonus Waddell accompanying his critical edition, Hymn Collections from the Paraclete, 2 vols. (Trappist, Ky.: Gethsemani Abbey, 1987-89); and Päivi Hannele Jussila, Peter Abelard on Imagery: Theory and Practice with Special Reference to His Hymns (Helsinki: Suomalainen Tiedeakatemia, 1995). I am grateful to Jussila for sending me a copy of her book. On the relationship between Abelard and Heloise, see most recently William G. East, "Educating Heloise," in Medieval Monastic Education, ed. Ferzoco and Muessig, 105-16; Constant Mews, The Lost Love Letters of Heloise and Abelard (New York: St. Martin's, 1999); and J. M. B. Porter, "The Convent of the Paraclete: Heloise, Abelard, and the Benedictine Tradition," Studia monastica 41 (1999): 151-69.

150. Constant Mews emphasizes that the initiative to create a new hymn repertory came from Heloise and that the preface is likely to reflect her statements accurately ("Heloise and Liturgical Experience at the Paraclete," Plainsong and Medieval Music 11 [2002]: 27).

151. "Tanta est frequenter inequalitas sillibarum, ut uix cantici melodiam recipiant, sine qua nullatenus ymnus consistere potest" (Waddell, ed., Hymn Collections from the Paraclete 2:5-9, at 6). 
variable. ${ }^{152}$ Apparently, in the first half of the twelfth century, matching hymn texts to melodies could present a challenge to singers.

Abelard's hymns for the Paraclete can be evaluated in light of these criticisms by Heloise. While his hymn texts are preserved, only one survives with an original melody: "O quanta qualia" for Vespers on Saturdays (see Ex. 1).153 Within the AABC structure of each strophe, a caesura divides each line into two balanced phrases. In the first two verses, the caesura is articulated by the leap of a fifth. Smaller intervals between phrases in the third and fourth lines create contrast and balance. The text accents in different strophes tend to be aligned at the same position in the line, creating a felicitous prosody that remedies the "inequality of syllables" deplored by Heloise. This carefully crafted composition, in which melody is closely bound to text, exudes a literate mode of composition, reflecting a departure from the conventions of the hymn repertory even while improving upon them. Abelard perhaps lived at the end of an era, but in any case his art no longer relied on the oral tradition.

Developments in the notation of the hymns from the eleventh to the twelfth century demonstrate that oral and written traditions coexisted in a relationship more complex than can be expressed by a polarity opposing orality to literacy. A remarkable diversity of notational methods appears not only in different manuscripts produced at the same time, but within the same book and even on the same page, reflecting the various needs and purposes of singers in their roles as cantors, scribes, and teachers. The transmission of hymns during the transitional period of the eleventh century suggests the range of possibilities inherent in musical notation. Understanding this phenomenon demands an ever subtler classification of notational types as well as closer attention to their historical and cultural contexts.

152. Giles Constable states that Abelard was referring to the tendency of some liturgical reformers to sing hypermetric lines without eliding their extra syllables ("The Concern for Sincerity and Understanding in Liturgical Prayer, Especially in the Twelfth Century," in Classica et Mediaevalia: Studies in Honor of Joseph Szöpérffy, ed. Irene Vaslef and Helmut Buschhausen [Washington, D.C., and Leyden: Classical Folia Editions, 1986], 21). David Wulstan argues that Abelard's statement shows the importance he placed on cadential accent as well as on elision and hiatus ("Novi modulaminis melos: The Music of Heloise and Abelard," Plainsong and Medieval Music 11 [2002]: 3-4).

153. On the melody and manuscript transmission of "O quanta qualia," see Waddell, ed., Hymn Collections from the Paraclete 1:45-54. Although Wulstan argues that the melody of "O quanta qualia" is not Abelard's own composition but instead is derived from a melody with a final on C ("Novi modulaminis melos," 13-14), the resemblance strikes me as coincidental. 


\section{Journal of the American Musicological Society}

Example 1 Peter Abelard, "O quanta qualia" (based on Chrysogonus Waddell, Hymn Collections from the Paraclete 1:50-51)

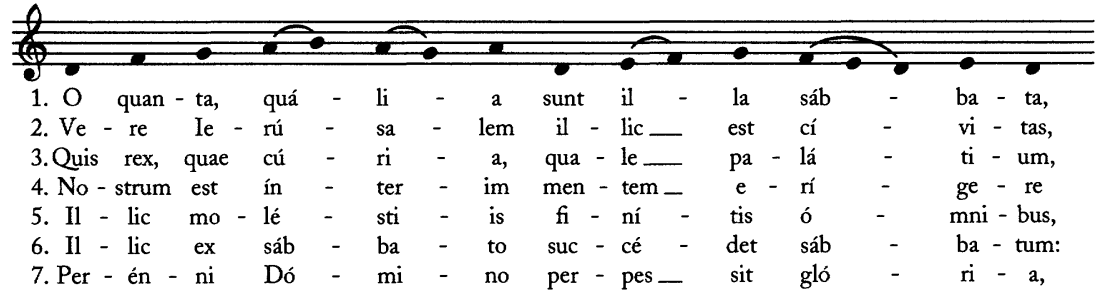
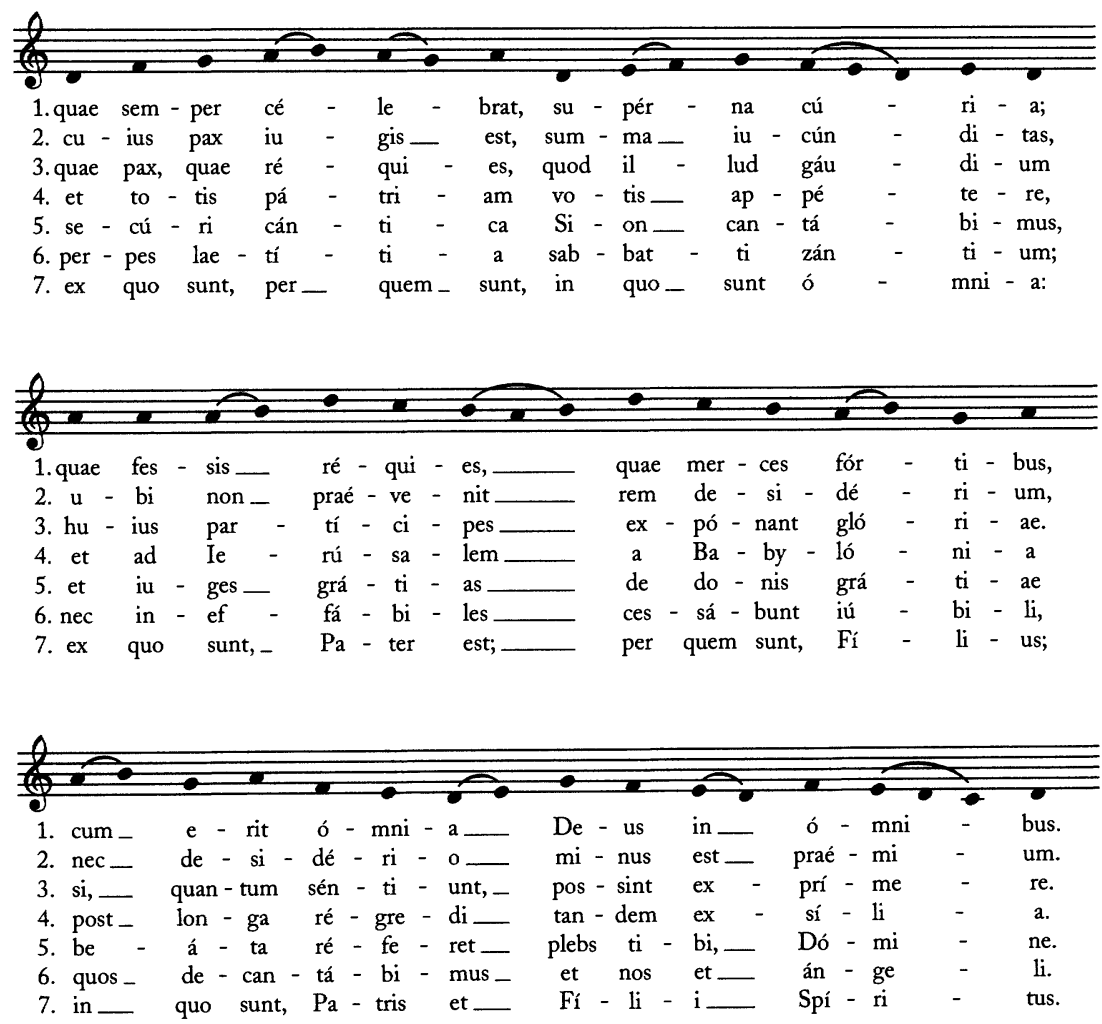


\section{Works Cited}

\section{Manuscripts}

Amiens, Bibliothèque Municipale, MS 131.

Benevento, Biblioteca Capitolare, MS 37.

Benevento, Biblioteca Capitolare, MS 42.

Berlin, Staatsbibliothek Preußischer Kulturbesitz, MS Theol. lat. $4^{0} 377$.

Cambridge, Corpus Christi College, MS 391.

Einsiedeln, Stiftsbibliothek, MS 366.

Evreux, Bibliothèque Municipale, MS 70.

Farfa, Biblioteca del Monumento Nazionale, MS A.209.

Florence, Biblioteca Medicea Laurenziana, MS Amiatino 1.

Huesca, Archivo de la Catedral, MS 1.

London, British Library, MS Add. 30848.

London, British Library, MS Cotton Julius A.VI.

Madrid, Biblioteca Nacional, MS 10001.

Manchester, John Rylands Library, MS 116.

Montecassino, Archivio dell'Abbazia, MS 420.

Munich, Bayerische Staatsbibliothek, MS lat. 17027.

Oxford, Bodleian Library, MS Misc. lit. 366.

Oxford, Bodleian Library, MS Laud misc. 468.

Paris, Bibliothèque Nationale de France, MS lat. 103.

Paris, Bibliothèque Nationale de France, MS lat. 776.

Paris, Bibliothèque Nationale de France, MS lat. 1085.

Paris, Bibliothèque Nationale de France, MS lat. 1087.

Paris, Bibliothèque Nationale de France, MS lat. 1092.

Paris, Bibliothèque Nationale de France, MS lat. 11550.

Paris, Bibliothèque Nationale de France, MS lat. 12584.

Paris, Bibliothèque Nationale de France, MS lat. 12601.

Paris, Bibliothèque Nationale de France, MS lat. 13875.

Paris, Bibliothèque Nationale de France, MS lat. 17791.

Paris, Bibliothèque Nationale de France, MS n.a.l. 1235.

Paris, Bibliothèque Nationale de France, MS n.a.l. 1236.

Rome, Biblioteca Casanatense, MS 1574.

Rome, Biblioteca Casanatense, MS 1907.

Rouen, Bibliothèque Municipale, MS 57.

Trier, Stadtbibliothek, MS 1245/597.

Troyes, Bibliothèque Municipale, MS 571.

Turin, Biblioteca Nazionale, MS G.V.38.

Turin, Biblioteca Nazionale, MS G.VII.18.

Utrecht, Bibliotheek der Rijksuniversiteit, MS 406 (3.J.7).

Vatican City, Biblioteca Apostolica Vaticana, MS Chigi C.VI.177.

Vatican City, Biblioteca Apostolica Vaticana, MS Ottob. lat. 145.

Vatican City, Biblioteca Apostolica Vaticana, MS Pal. lat. 220.

Vatican City, Biblioteca Apostolica Vaticana, MS Reg. lat. 338.

Vatican City, Biblioteca Apostolica Vaticana, MS Rossi 205.

Vatican City, Biblioteca Apostolica Vaticana, MS Vat. lat. 3797.

Vatican City, Biblioteca Apostolica Vaticana, MS Vat. lat. 5776. 
Vatican City, Biblioteca Apostolica Vaticana, MS Vat. lat. 6808.

Vatican City, Biblioteca Apostolica Vaticana, MS Vat. lat. 7018.

Vatican City, Biblioteca Apostolica Vaticana, MS Vat. lat. 7172.

Verona, Biblioteca Capitolare, MS CIX (102).

Worcester, Cathedral Library, MS F.160.

Zurich, Zentralbibliothek, MS Rheinau 82.

Zurich, Zentralbibliothek, MS Rheinau 83.

Zurich, Zentralbibliothek, MS Rheinau 97.

Zurich, Zentralbibliothek, MS Rheinau 111.

\section{Editions}

Aimericus. Ars lectoria. Edited by Harry Reijnders. Vivarium 9 (1971): 119-37; 10 (1972): 41-101, 124-76.

Ambrose of Milan. Ambroise de Milan: Hymnes. Edited by Jacques Fontaine et al. Paris: Cerf, 1992.

Analecta hymnica medii aevi. 55 vols. Edited by Clemens Blume and Guido Maria Dreves. Leipzig: O. R. Reisland, 1886-1922.

Antiphonaire monastique, XIIIe siècle: Codex F.160 de la Bibliothèque de la Catbédrale de Worcester. Paléographie Musicale 12. Tournai: Desclée, 1922.

Augustine of Hippo. Quaestiones euangeliorum. Edited by Almut Mutzenbecher. Corpus Christianorum Series Latina 44B. Turnhout: Brepols, 1980.

Bernard. "Ordo cluniacensis." In Vetus disciplina monastica, edited by Marquard Herrgott, 133-64. Paris: Osmont, 1726. Reprint, Siegburg: Franz Schmitt, 1999.

Bernard, J. H., and R. Atkinson, eds. The Irish Liber Hymnorum. Henry Bradshaw Society 13. London: Henry Bradshaw Society, 1898.

Dinter, Peter, ed. Liber tramitis aeui Odilonis abbatis. Corpus Consuetudinum Monasticarum 10. Siegburg: Franz Schmitt, 1980.

Durán, Antonio, Ramón Moragas, and Juan Villarreal, eds. Hymnarium Oscense (S. XI). 2 vols. Zaragoza: Institución Fernando el Católico, 1987.

Emerson, John. Albi, Bibliothèque Municipale Rochegude, Manuscript 44: A Complete Ninth-Century Gradual and Antiphoner from Southern France. Edited by Lila Collamore. Wissenschaftliche Abhandlungen 77. Ottawa: Institute of Mediaeval Music, 2002.

Gransden, Antonia, ed. The Customary of the Benedictine Abbey of Bury St Edmunds in Suffolk (from Harleian Ms. 1005 in the British Museum). Henry Bradshaw Society 99. Chichester: Morre and Tillyer, 1973.

Guido d'Arezzo. Guido d'Arezzo's Regule rithmice, Prologus in antiphonarium, and Epistola ad michaehelem. Edited and translated by Dolores Pesce. Ottawa: Institute of Mediaeval Music, 1999.

Isidore of Seville. De ecclesiasticis officiis. Edited by Christopher Lawson. Corpus Christianorum Series Latina 113. Turnhout: Brepols, 1989.

- Isidori Hispalensis episcopi Etymologiarum siue originum libri XX. Edited by W. M. Lindsay. Oxford: Clarendon Press, 1911.

Jerome. Commentariorum in enangelium Matthaei libri IV. Edited by D. Hurst and M. Adriaen. Corpus Christianorum Series Latina 77. Turnhout: Brepols, 1969.

. Sancti Eusebii Hieronymi Epistulae. Edited by Isidore Hilberg. Corpus Scriptorum Ecclesiasticorum Latinorum 21. Vienna: Tempsky; Leipzig: Freytag, 1910. 
Jocqué, Luc, and Ludo Milis, eds. Liber ordinis S. Victoris Parisiensis. Corpus Christianorum Continuatio Mediaeualis 61. Turnhout: Brepols, 1984.

Lokrantz, Margareta, ed. L'opera poetica di s. Pier Damiani. Studia Latina Stockholmiensia 12. Stockholm: Almqvist \& Wiksell, 1964.

Odilo of Cluny. De vita beati Maioli abbatis libellus. In Patrologiae cursus completus: Series latina, edited by J.-P. Migne, vol. 142, cols. 943-62. Paris: Migne, 1853.

Semmler, Josef, ed. Consuetudines saeculi octavi et noni. Corpus Consuetudinum Monasticarum 1. Siegburg: Franz Schmitt, 1963.

Sievers, Eduard, ed. Die Murbacher Hymnen. Halle: Verlag der Buchhandlung des Waisenhauses, 1874.

Siguinus. Ars lectoria: Un art de lecture à haute voix du onzième siècle. Edited by Joseph Engels, C. H. Kneepkens, and Harry Reijnders. Leiden: Brill, 1979.

Sivo, Vito, ed. Ars lectoria e codice Parisino Latino 8499. Bari: Levante, 1990.

Spätling, Luchesius, and Peter Dinter, eds. Consuetudines fructuarienses-Sanblasianae. 2 vols. Corpus Consuetudinum Monasticarum 12. Siegburg: Franz Schmitt, 1987.

Stäblein, Bruno, ed. Hymnen: Die mittelalterlichen Hymnenmelodien des Abendlandes. Monumenta Monodica Medii Aevi 1. Kassel and Basel: Bärenreiter, 1956.

Ulrich of Zell. Antiquiores consuetudines monasterii Cluniacensis. In Patrologiae cursus completus: Series latina, edited by J.-P. Migne, vol. 149, cols. 658-778. Paris: Migne, 1853.

\section{Secondary Sources}

Allen, Judson. "Commentary as Criticism: The Late Medieval Accessus." In Acta Conventus Neo-Latini Lovaniensis: Proceedings of the First International Congress of NeoLatin Studies, Louvain, 23-28 August 1971, edited by Jozef Ijsewijn and Eckhard Keßler, 29-48. Leuven: Leuven University Press; Munich: Wilhelm Fink, 1973.

Bannister, Henry Marriott. Monumenti vaticani di paleografia musicale latina. Leipzig: Harrassowitz, 1913.

—. [Untitled]. In Rassegna gregoriana 7 (1908): 262-64.

Barrett, Sam. "Music and Writing: On the Compilation of Paris, Bibliothèque Nationale lat. 1154." Early Music History 16 (1997): 55-96.

Bibliotheca sanctorum. Rome: Istituto Giovanni XXIII nella Pontificia Universita lateranense, 1961-70. 12 vols.

Blum, Owen. "Alberic of Monte Cassino and the Hymns and Rhythms Attributed to Saint Peter Damian." Traditio 12 (1956): 87-148.

Borders, James. "The Cathedral of Verona as a Musical Center in the Middle Ages: Its History, Manuscripts, and Liturgical Practice." Ph.D. diss., University of Chicago, 1983.

Bourgain, Pascale. "Les chansonniers lyriques latins." In Lyrique romane médiépale: $L a$ tradition des chansonniers. Actes du colloque de Liège, 1989, edited by Madeleine Tyssens, 61-84. Bibliothèque de la Faculté de Philosophie et Lettres de l'Université de Liège 258. Liège: Faculté de Philosophie et Lettres de l'Université de Liège, 1991.

- "Les receuils carolingiens de poésie rhythmique." In De Tertullien aux Mozarabes, edited by Louis Holtz and Jean-Claude Fredouille, with Marie-Hélène Jullien, 1:117-27. Paris: Institut des études augustiniennes, 1992.

Boynton, Susan. "Eleventh-Century Continental Hymnaries Containing Latin Glosses." Scriptorium 53 (1999): 200-251. 
"Glossed Hymns in Eleventh-Century Continental Hymnaries." Ph.D. diss., Brandeis University, 1997.

__. "Glosses on the Office Hymns in Eleventh-Century Continental Hymnaries." The Journal of Medieval Latin 11 (2001): 1-26.

- "The Liturgical Role of Children in Monastic Customaries from the Central Middle Ages." Studia liturgica 28 (1998): 194-209.

- "Liturgy and History at the Abbey of Farfa in the Late Eleventh Century: Hymns of Peter Damian and Other Additions to BAV Chigi C.VI.177." Sacris erudiri 39 (2000): 253-80.

. Review of Gregorian Chant and the Carolingians, by Kenneth Levy, and Aspects of Orality and Formularity in Gregorian Chant, by Theodore Karp. This Journal 53 (2000): 141-52.

- "Training for the Liturgy as a Form of Monastic Education." In Medieval Monastic Education, edited by George Ferzoco and Carolyn Muessig, 13-20. London and New York: Leicester University Press, 2000.

Brou, Louis. "Notes de paléographie musicale mozarabe." Anuario musical 10 (1955): 23-29.

Busse Berger, Anna Maria. "Mnemotechnics and Notre Dame Polyphony." Journal of Musicology 14 (1996): 263-98.

Carruthers, Mary. The Book of Memory: A Study of Memory in Medieval Culture. Cambridge: Cambridge University Press, 1990.

- The Craft of Thought: Meditation, Rhetoric, and the Making of Images, 400-1200. Cambridge: Cambridge University Press, 1998.

Chailley, Jacques. " 'Ut queant laxis' et les origines de la gamme." Acta musicologica 56 (1984): 48-69.

Chailley, Jacques, and Jacques Viret. "Le symbolisme de la gamme." La repue musicale 408-9 (1988): 7-150.

Clanchy, Michael T. From Memory to Written Record: England, 1066-1307. 2d ed. Oxford: Blackwell, 1993.

Cochelin, Isabelle. "Besides the Book: Using the Body to Mould the Mind-Cluny in the Tenth and Eleventh Centuries." In Medieval Monastic Education, edited by George Ferzoco and Carolyn Muessig, 21-34. London and New York: Leicester University Press, 2000.

—. "Le dur apprentissage de la virginité: Cluny, XIe siècle." In Au cloître et dansle monde: Femmes, hommes et sociétés (IXe-XVe siècle). Mélanges en l'bonneur de Paulette L'Hermite-Leclercq, edited by Patrick Henriet and Anne-Marie Legras, 119-32. Paris: Presses de l'Université de Paris-Sorbonne, 2000.

_ "Peut-on parler de noviciat à Cluny pour les Xe-XIe siècles?" Revue Mabillon 70 (1998): 17-52.

—. "La singularité de l'oeuvre de Bernard au regard de l'histoire des coutumiers." In From Dead of Night to End of Day: The Medieval Customs of Cluny, edited by Susan Boynton and Isabelle Cochelin. Disciplina Monastica 2. Turnhout: Brepols, forthcoming in 2004.

I codici liturgici della Cattedrale di Verona. Verona: Biblioteca Capitolare, 1987.

Collamore, Lila. "Aquitanian Collections of Office Chants: A Comparative Survey." Ph.D. diss., Catholic University of America, 2000. 
Constable, Giles. "The Concern for Sincerity and Understanding in Liturgical Prayer, Especially in the Twelfth Century." In Classica et Mediaevalia: Studies in Honor of Joseph Szöpérffy, edited by Irene Vaslef and Helmut Buschhausen, 17-30. Washington, D.C., and Leyden: Classical Folia Editions, 1986.

- "Monastic Legislation at Cluny in the Eleventh and Twelfth Centuries." Proceedings of the Fourth International Congress of Medieval Canon Law. Monumenta Iuris Canonici, ser. C, subsidia 5, 151-61. Vatican City: Biblioteca Apostolica Vaticana, 1976. Reprinted in Giles Constable, Cluniac Studies (London: Variorum Reprints, 1980).

- The Reformation of the Twelfth Century. Cambridge and New York: Cambridge University Press, 1996.

- Three Studies in Medieval Religious and Social Thought. Cambridge: Cambridge University Press, 1995.

Correa, Alice. "The Liturgical Manuscripts of Oswald's Houses." In St. Oswald of Worcester: Life and Influence, edited by Nicholas Brooks and Catherine Cubitt, 285-324. London and New York: Leicester University Press, 1996.

Cottineau, Laurent-Henri. Répertoire topo-bibliographique des abbayes et prieurés. 3 vols. Mâcon: Protat, 1939.

Crocker, Richard. "Gregorian Studies in the Twenty-first Century." Plainsong and Medieval Music 4 (1995): 33-86.

Cygler, Florent. "L'ordre de Cluny et les rebelliones au XIIIe siècle." Francia 19 (1992): 61-93.

Cygler, Florent, Gert Melville, and Jörg Oberste. “Aspekte zur Verbindung von Organisation und Schriftlichkeit im Ordenswesen: Ein Vergleich zwischen den Zisterziensern und Cluniazensern des 12./13. Jahrhunderts." In Viva vox und ratio scripta: Mündliche und schriftliche Kommunikationsformen im Mönchtum des Mittelalters, edited by Clemens Kasper and Klaus Schreiner, 205-80. Vita regularis 5. Münster: LIT Verlag, 1997.

Dachowski, Elizabeth. "Tertius est optimus: Marriage, Continence, and Virginity in the Politics of Late Tenth- and Early Eleventh-Century Francia." In Medieval Purity and Piety: Essays on Medieval Clerical Celibacy and Religious Reform, edited by Michael Frassetto, 117-29. New York and London: Garland, 1998.

Daniel, Natalia. Handschriften des zehnten Jabrhunderts aus der Freisinger Dombibliothek. Munich: Arbeo-Gesellschaft, 1973.

Donnat, Lin. "Les coutumiers monastiques: Une nouvelle entreprise et un territoire nouveau." Revue Mabillon 64 (1992): 5-21.

East, William G. "Educating Heloise." In Medieval Monastic Education, edited by George Ferzoco and Carolyn Muessig, 105-16. London and New York: Leicester University Press, 2000.

Ebel, Basilius. Das älteste alemannische Hymnar mit Noten, Kodex 366 Einsiedeln (XII. Jahrbundert). Einsiedeln: Benziger, 1930.

Elich, Tom. "Le contexte oral de la liturgie médiévale et le rôle du texte écrit." 3 vols. Ph.D. diss, Institut Catholique, Paris, 1988.

. "Using Liturgical Texts in the Middle Ages." In Fountain of Life: In Memory of Nils K. Rasmussen, O.P., edited by Gerard Austin, 69-83. Washington, D.C.: Pastoral Press, 1991. 
Emms, Richard. "The Historical Traditions of St Augustine's Abbey, Canterbury." In Canterbury and the Norman Conquest, edited by Richard Eales and Richard Sharpe, 159-68. London: Hambledon Press, 1995.

Ernst, Josef. Johannes der Täufer: Interpretation-Geschichte-Wirkungsgeschichte. Berlin and New York: Walter de Gruyter, 1989.

Fassler, Margot. Gothic Song: Victorine Sequences and Augustinian Reform in TwelfthCentury Paris. Cambridge: Cambridge University Press, 1993.

- "The Office of the Cantor in Early Western Monastic Rules and Customaries: A Preliminary Investigation." Early Music History 5 (1985): 29-51.

Feller, Laurent. "Le cartulaire-chronique de San Clemente a Casauria." In Les cartulaires: Actes de la table ronde organisée par l'École nationale des chartes et le G.D.R 121 du C.N.R.S (Paris, 5-7 septembre 1991), edited by Olivier Guyotjeannin, Laurent Morelle, and Michel Parisse, 261-77. Mémoires et documents de l'École des chartes 39. Paris: École nationale des chartes, 1993.

Fentress, James, and Chris Wickham. Social Memory. Oxford: Blackwell, 1992.

Gamber, Klaus. Codices liturgici Latini antiquiores: Supplementum. Freiburg: Universitätsverlag, 1988.

Geary, Patrick. Phantoms of Remembrance: Memory and Oblivion at the End of the First Millennium. Princeton: Princeton University Press, 1994.

Giorgi, Ignazio. "Il regesto di Farfa e le altre opere di Gregorio di Catino." Archivio della reale società romana di storia patria 2 (1879): 409-73.

Gneuss, Helmut. "Zur Geschichte des Hymnars." Mittellateinisches Jabrbuch 35 (2000): 227-47.

- Hymnar und Hymnen im englischen Mittelalter: Studien zur Überlieferung, Glossierung und Übersetzung lateinischer Hymnen in England. Buchreihe der Anglia 12. Tübingen: Max Niemeyer, 1968.

Grégoire, Réginald. "Repertorium liturgicum italicum." Studi medievali, n.s. 9 (1968): 465-592.

Grier, James. "The Divine Office at Saint-Martial in the Early Eleventh Century: Paris, BNF lat. 1085." In The Divine Office in the Latin Middle Ages: Methodology and Source Studies, Regional Developments, Hagiography, edited by Margot Fassler and Rebecca Baltzer, 179-204. New York: Oxford University Press, 2000.

- "Scribal Practices in the Aquitanian Versaria of the Twelfth Century: Towards a Typology of Error and Variant." This Journal 45 (1992): 373-427.

Guéry, Charles. Histoire de l'Abbaye de Lyre. Evreux: Imprimerie de l'Eure, 1917.

Hallinger, Kassius. "Consuetudo: Begriff, Formen, Forschungsgeschichte, Inhalt." In Untersuchungen zu Kloster und Stift, 140-66. Veröffentlichungen des Max-Plancks Instituts für Geschichte 68. Göttingen: Max-Plancks Institut, 1980.

Harbinson, Denis. "The Hymn 'Ut queant laxis.' " Music and Letters 52 (1971): $55-58$.

Haug, Andreas. "Zur Interpretation der Liqueszenzneumen." Archiv für Musikwissenschaft 50 (1993): 85-100.

- "Zum Wechselspiel von Schrift und Gedächtnis im Zeitalter der Neumen." In International Musicological Society Study Group Cantus Planus: Papers Read at the Third Meeting, Tỉány, Hungary, 19-24 September 1988, edited by László Dobszay et al., 33-47. Budapest: Hungarian Academy of Sciences, 1990.

Heinzer, Felix. "Kodifizierung und Vereinheitlichung liturgischer Traditionen: Historisches Phänomen und Interpretationsschlüssel handschriftlicher Überliefer- 
ung." In Musik in Mecklenburg: Beitrüge eines Kolloquiums zur mecklenburgischen Musikgeschichte, edited by Karl Heller, Hartmut Möller, and Andreas Waczkat, 85-106. Hildesheim: Georg Olms, 2000.

Hoffmann, Hartmut. Buchkunst und Königtum im ottonischen und frühsalischen Reich. 2 vols. Stuttgart: Hiersemann, 1986.

Hunt, Noreen. Cluny Under Saint Hugh, 1040-1109. Notre Dame, Ind.: University of Notre Dame Press, 1968.

Innes, Matthew. "Memory, Orality and Literacy in Early Medieval Society." Past and Present 158 (1998): 3-36.

Iogna-Prat, Dominique. Agni Immaculati: Recherches sur les sources hagiographiques relatives à Saint Maieul de Cluny (954-994). Paris: Cerf, 1986.

—_. "Coutumes et statuts clunisiens comme sources historiques (ca 990-1200)." Revue Mabillon 64 (1992): 23-48.

- "The Dead in the Celestial Bookkeeping of the Cluniac Monks Around the Year 1000." In Debating the Middle Ages, edited by Lester Little and Barbara Rosenwein, 340-62. Oxford: Blackwell, 1998. Translation of "Les morts dans la compatibilité céleste des moines clunisiens autour de l'an Mil," in Religion et culture autour de l'an Mil: Royaume capétien et Lotharingie, ed. Dominique IognaPrat and Jean-Charles Picard (Paris: Picard, 1990), 55-69.

—_. "La geste des origines dans l'historiographie clunisienne des XIe-XIIe siècles." Revue bénédictine 102 (1992): 125-91.

- Ordonner et exclure: Cluny et la société chrétienne face à l'hérésie, au judaïsme et à lislam, 1000-1150. Paris: Aubier, 1998.

Irvine, Martin. The Making of Textual Culture: "Grammatica” and Literary Theory, 350-1100. Cambridge: Cambridge University Press, 1994.

Jeffery, Peter. Re-envisioning Past Musical Cultures: Ethnomusicology in the Study of Gregorian Chant. Chicago and London: University of Chicago Press, 1992.

Jullien, Marie-Hélène. "Les sources de la tradition ancienne des quatorze Hymnes attribuées à saint Ambroise de Milan." Revue d'histoire des textes 19 (1989): 57-189.

Jussila, Päivi Hannele. Peter Abelard on Imagery: Theory and Practice with Special Reference to His Hymns. Helsinki: Suomalainen Tiedeakatemia, 1995.

Kasper, Clemens. "Text und Ton: Beobachtungen zur Bewertung des Verhältnisses von Musik, Text und Sprache bei der Verschriftlichung des Chorals." In Viva vox und ratio scripta: Mündliche und schriftliche Kommunikationsformen im Mönchtum des Mittelalters, edited by Clemens Kasper and Klaus Schreiner, 157-76. Vita Regularis 5. Münster: LIT Verlag, 1997.

Kazmierski, Carl. John the Baptist: Prophet and Evangelist. Collegeville, Minn.: Liturgical Press, 1996.

Kelly, Thomas Forrest, ed. La cathédrale de Bénévent. Ghent and Amsterdam: Ludion, 1999.

Kruckenberg, Lori. “Sequenz." In Die Musik in Geschichte und Gegenwart, $2 \mathrm{~d}$ rev. ed., ed. Ludwig Finscher, Sachteil, vol. 8, cols. 1254-86. Kassel: Bärenreiter, 1998.

Leclercq, Jean. "Les études dans les monastères du Xe au XIIe siècle." In Los monjes y los estudios: IV Semana de estudios monasticos, 105-17. Poblet: Abadia de Poblet, 1963.

. The Love of Learning and the Desire for God: A Study of Monastic Culture. Translated by Catharine Misrahi. 3d ed. New York: Fordham University Press, 1982. 
"The Monastic Tradition of Culture and Studies." American Benedictine Review 11 (1960): 99-131.

Leroquais, Victor. Les psautiers manuscrits latins des bibliothèques publiques de France. 3 vols. Mâcon: Protat, 1940-41.

Levy, Kenneth. "Charlemagne's Archetype of Gregorian Chant." This Journal 40 (1987): 1-30.

—."From Aural to Notational: The Gregorian Antiphonale Missarum." Études grégoriennes 28 (2000): 5-19.

Gregorian Chant and the Carolingians. Princeton: Princeton University Press, 1998.

Lucchesi, Giovanni. "Per la storia faentina del cod. Vat. Lat. 3797." In San Pier Damiano nel IX centenario della morte, 1072-1972, 3:207-12. Cesena: Centro studi e ricerche sulla antica provincia ecclesiastica ravennate, 1973.

Mallet, Jean, and André Thibaut. Les manuscrits en écriture bénéventaine de la Bibliothèque Capitulaire de Bénépent. 2 vols. Paris and Turnhout: CNRS/Brepols, 1997.

McGee, Timothy. The Sound of Medieval Song: Ornamentation and Vocal Style According to the Treatises. Oxford: Clarendon, 1998.

McKitterick, Rosamond. The Carolingians and the Written Word. Cambridge: Cambridge University Press, 1989.

- ed. The Uses of Literacy in Early Mediaeval Europe. Cambridge: Cambridge University Press, 1990.

McLaughlin, Megan. Consorting with Saints: Prayer for the Dead in Early Medieval France. Ithaca and London: Cornell University Press, 1994.

McNally, Robert. " 'In nomine dei summi': Seven Hiberno-Latin Sermons." Traditio 35 (1979): 121-43.

Mearns, James. Early Latin Hymnaries. Cambridge: Cambridge University Press, 1913.

Melville, Gert. "Cluny après 'Cluny.' Le treizième siècle: Un champ de recherches." Francia 17, no. 1 (1990): 91-124.

- "From the Cluny of 'Consuetudines' to the Cluny of 'Statuta': A Changing from the Past to the Future." In From Dead of Night to End of Day: The Medieval Customs of Cluny, edited by Susan Boynton and Isabelle Cochelin. Disciplina Monastica 2. Turnhout: Brepols, forthcoming in 2004.

- "Von der Regula regularum zur Stephansregel: Der normative Sonderweg der Grandmontenser bei der Auffächerung der vita religiosa im 12. Jahrhundert." In Vom Kloster zum Klosterverband: Das Werkzeug der Schriftlichkeit, edited by Hagen Keller and Franz Neiske, 342-63. Münstersche Mittelalter-Schriften 74. Munich: Wilhelm Fink, 1997.

Mews, Constant. "Heloise and Liturgical Experience at the Paraclete." Plainsong and Medieval Music 11 (2002): 25-35.

The Lost Lope Letters of Heloise and Abelard. New York: St. Martin's, 1999.

Milfull, Inge. The Hymns of the Anglo-Saxon Church. Cambridge Studies in AngloSaxon England 17. Cambridge: Cambridge University Press, 1996.

Milis, Ludo. Angelic Monks and Earthly Men. Woodbridge: Boydell and Brewer, 1992.

Miller, Maureen. The Formation of a Medieval Church: Ecclesiastical Change in Verona, 950-1150. Ithaca, N.Y., and London: Cornell University Press, 1993.

Moberg, Carl-Allan. "Die Musik in Guido von Arezzos Solmisationshymne." Archiv für Musikwissenschaft 16 (1959): 186-206. 
Mohlberg, Leo Cunibert. Mittelalterliche Handschriften. 4 vols. Part 1 of Katalog der Handschriften der Zentralbibliothek Zürich. Zurich: Zentralbibliothek, 1932-52.

Möller, Hartmut. "Die Prosula 'Psalle modulamina' (Mü 9543) und ihre musikhistorische Bedeutung." In La tradizione dei tropi liturgici, edited by Claudio Leonardi and Enrico Menestò, 279-301. Spoleto: Centro Italiano di Studi sull'Alto Medioevo, 1993.

Mostert, Marco. "New Approaches to Medieval Communication?" In New Approaches to Medieval Communication, edited by Marco Mostert, 15-37. Turnhout: Brepols, 1999.

Nortier, Geneviève. Les bibliotbèques médiévales des abbayes bénédictines de Normandie. Paris: Lethielleux, 1971.

Omlin, Ephrem. "Guido von Arezzo und der Johanneshymnus Ut queant laxis." In J. B. Hilber: Festgabe zu seinem 60. Geburtstage, 46-54. Altdorf: Schweizer Kirchenmusikverlag, 1951.

Omont, Henri. Rouen. Vols. 1-2 of Catalogue général des manuscrits des bibliothèques publiques de France, Départements. Paris: Plon, 1886-88.

Palazzo, Eric. A History of Liturgical Books from the Beginning to the Thirteenth Century, trans. Madeleine Beaumont (Collegeville, Minn.: The Liturgical Press, 1998). Originally published as Histoire des livres liturgiques: Le Moyen Age, des origines au XIIIe siècle (Paris: Beauchesne, 1993).

Palisca, Claude. "Guido of Arezzo." In The New Grove Dictionary of Music and Musicians, edited by Stanley Sadie, 7:803-7. London: Macmillan, 1980.

Penco, Gregorio. "S. Giovanni Battista nel ricordo del monachesimo medievale." Studia monastica 3 (1961): 7-32.

Planchart, Alejandro Enrique. "On the Nature of Transmission and Change in Trope Repertories." This Journal 41 (1988): 215-49.

Poeck, Dietrich. Cluniacensis Ecclesia: Der cluniacensische Klosterverband (10.-12. Jabrhundert). Münstersche Mittelalter-Schriften 71. Munich: Wilhelm Fink, 1998.

Porter, J. M. B. "The Convent of the Paraclete: Heloise, Abelard, and the Benedictine Tradition." Studia monastica 41 (1999): 151-69.

Potts, Cassandra. Monastic Revival and Regional Identity in Early Normandy. Woodbridge: Boydell, 1997.

Rampolla, Mary Lynn. “'A Pious Legend': St. Oswald and the Foundation of Worcester Cathedral Priory." In Oral Tradition in the Middle Ages, edited by W. F. H. Nicolaisen, 187-210. Medieval and Renaissance Texts and Studies 112. Binghamton, N.Y.: Center for Medieval and Early Renaissance Studies, State University of New York at Binghamton, 1995.

Rankin, Susan. "Neumatic Notations in Anglo-Saxon England." In Musicologie médiévale: Notations et séquences, edited by Michel Huglo, 129-44. Paris: Champion, 1987.

"Some Reflections on Liturgical Music at Late Anglo-Saxon Worcester." In St. Oswald of Worcester: Life and Influence, edited by Nicholas Brooks and Catherine Cubitt, 325-48. London and New York: Leicester University Press, 1996.

Reindel, Kurt. "Zur handschriftlichen Überlieferung der Gedichte des Petrus Damiani." Revue bénédictine 67 (1957): 182-89.

- "Studien zur Überlieferung der Werke des Petrus Damiani, I." Deutsches Archiv für Erforschung des Mittelalters 15 (1959): 23-102.

Remensnyder, Amy. "Legendary Treasure at Conques: Reliquaries and Imaginative Memory." Speculum 71 (1996): 885-906. 
Remembering Kings Past: Monastic Foundation Legends in Medieval Southern France. Ithaca, N.Y., and London: Cornell University Press, 1995.

Reynolds, Suzanne. Medieval Reading: Grammar, Rhetoric and the Classical Text. Cambridge: Cambridge University Press, 1996.

Robinson, Pam. Catalogue of Dated and Datable Manuscripts c. 737-1600 in Cambridge Libraries. Cambridge: Brewer, 1988.

Rosenwein, Barbara. Rhinoceros Bound: Cluny in the Tenth Century. Philadelphia: University of Pennsylvania Press, 1982.

Rubin, David. Memory in Oral Traditions: The Cognitive Psychology of Epic, Ballads, and Counting-out Rhymes. New York: Oxford University Press, 1995.

Schmid, Karl, and Joachim Wollasch, eds. Memoria: Der geschichtliche Zeugniswert des liturgischen Gedenkens im Mittelalter. Münstersche Mittelalter-Schriften 48. Munich: Wilhelm Fink, 1984.

Schreiner, Klaus. "Verschriftlichung als Faktor monastischer Reform: Funktionen von Schriftlichkeit im Ordenswesen des hohen und späten Mittelalters." In Pragmatische Schriftlichkeit im Mittelalter: Erscheinungsformen und Entwicklungsstufen, edited by Hagen Keller, Klaus Grubmüller, and Nikolaus Staubach, 37-75. Münstersche Mittelalter-Schriften 65. Munich: Wilhelm Fink, 1992.

La scuola nell'occidente latino dell'alto medioevo. Settimane di studio del Centro italiano di studi sull'alto medioevo 19. Spoleto: Centro Italiano di Studi sull'Alto Medioevo, 1972.

Shelemay, Kay Kaufman, Peter Jeffery, and Ingrid Monson. "Oral and Written Transmission in Ethiopian Christian Chant." Early Music History 12 (1993): 55-117.

Shopkow, Leah. History and Community: Norman Historical Writing in the Eleventh and Twelfth Centuries. Washington, D.C.: Catholic University of America, 1997.

Smits van Waesberghe, Joseph. De musico-paedagogico et theoretico Guidone Aretino eiusque vita et moribus. Florence: Olschki, 1953.

Snyder, Bob. Music and Memory: An Introduction. Cambridge, Mass., and London: MIT Press, 2000.

Spagnolo, Antonio. I manoscritti della Biblioteca Capitolare di Verona. Edited by Silvia Marchi. Verona: Casa Editrice Mazziana, 1996.

Steiner, Ruth. "Hymn." Sec. II, "Monophonic Latin." In The New Grove Dictionary of Music and Musicians, edited by Stanley Sadie, 8:838-41. London: MacMillan, 1980.

Stock, Brian. The Implications of Literacy: Written Language and Models of Interpretation in the Eleventh and Twelfth Centuries. Princeton: Princeton University Press, 1983.

Stotz, Peter. "Poesie auf dem Exerzierfeld: Über einen sprachlichen Kommentar zu dem Hymnus Ut queant laxis auf Johannes den Täufer." In Italica-RaeticaGallica: Studia linguarum litterarum artiumque in bonorem Ricarda Liver, edited by Peter Wunderli, Iwar Werlen, and Matthias Grünert, 637-53. Tübingen and Basel: A. Francke, 2001.

Supino Martini, Paola. Roma e l'area grafica romanesca (secoli X-XII). Alessandria: Edizioni dell'Orso, 1987.

Treitler, Leo. "Oral, Written, and Literate Process in the Transmission of Medieval Music." Speculum 56 (1981): 471-91.

_. "Reading and Singing: On the Genesis of Occidental Music-Writing." Early Music History 4 (1984): 135-208. 
- "The 'Unwritten' and 'Written Transmission' of Medieval Chant and the Start-up of Musical Notation." Journal of Musicology 10 (1992): 131-91.

Tutsch, Burkhardt. "Zur Rezeptionsgeschichte der Consuetudines Bernards und Ulrichs von Cluny." In Schriftlichkeit und Lebenspraxis im Mittelalter: Erfassen, Bewahren, Veründern, edited by Hagen Keller, Christel Meier, and Thomas Scharff, 79-94. Münstersche Mittelalter-Schriften 76. Munich: Wilhelm Fink, 1999.

- "Die Rezeptionsgeschichte der Consuetudines Bernhards und Ulrichs von Cluny im Spiegel ihrer handschriftlichen Überlieferung." Frübmittelalterliche Studien 30 (1996): 248-93.

- Studien zur Rezeptionsgeschichte der Consuetudines Ulrichs von Cluny. Vita Regularis 6. Münster: LIT Verlag, 1998.

- "Texttradition und Praxis von consuetudines und statuta in der Cluniacensis ecclesia (10.-12. Jahrhundert)." In Vom Kloster zum Klosterverband: Das Werkzeug der Schriftlichkeit, edited by Hagen Keller and Franz Neiske, 173-205. Münstersche Mittelalter-Schriften 74. Munich: Wilhelm Fink, 1997.

Valdez del Alamo, Elizabeth, ed., with Carol Pendergast. Memory and the Medieval Tomb. Aldershot: Ashgate, 2000.

van Dijk, Stephen Joseph Peter. "Handlist of the Latin Liturgical Manuscripts in the Bodleian Library, Oxford." 7 vols. Oxford, Bodleian Library, 1957. Typescript.

van Houts, Elisabeth. Memory and Gender in Medieval Europe, 900-1200. Toronto and Buffalo: University of Toronto Press, 1999.

Viard, Paul. "Ebrulfo." In Bibliotheca sanctorum, vol. 4, cols. 893-94. Rome: Società grafica romana, 1964.

Viret, Jacques. "Un cryptogramme carolingien du Christ-Soleil." In Le soleil, la lune et les étoiles au moyen âge, 421-35. Sénéfiance 13. Aix-en-Provence: Université de Provence; Marseille: Laffitte, 1983.

Waddell, Chrysogonus, ed. Hymn Collections from the Paraclete. 2 vols. Trappist, Ky.: Gethsemani Abbey, 1987-89.

Wailes, Stephen. Medieval Allegories of Jesus' Parables. Berkeley and Los Angeles: University of California Press, 1987.

Wallace, Wanda T. "Memory for Music: Effect of Melody on Recall of Text." Journal of Experimental Psychology: Learning, Memory, and Cognition 20 (1994): 1471-85.

Ward, John. "The Monastic Historiographical Impulse, c. 1000-1260: A Reassessment." In Historia: The Concept and Genres in the Middle Ages, edited by Tuomas M. S. Lehtonen and Päivi Mehtonen, 71-100. Commentationes Humanarum Litterarum 116. Helsinki: Societas Scientiarum Fennica, 2000.

Wieland, Gernot. "The Prudentius Manuscript CCCC 223.” Manuscripta 38 (1994): 211-27.

Wilmart, André. Codices reginenses latini. Vol. 2, Codices 251-500. Vatican City: Biblioteca Apostolica Vaticana, 1945.

—. "Le recueil des poèmes et des prières de saint Pierre Damien." Revue bénédictine 41 (1929): 342-57.

Wollasch, Joachim. Cluny - "Licht der Welt”: Aufstieg und Niedergang der klösterlichen Gemeinschaft. Zurich: Artemis und Winkler, 1996.

"Zur Datierung des Liber tramitis aus Farfa anhand von Personen und Personengruppen." In Person und Gemeinschaft im Mittelalter: Karl Schmid zum fünfundsechzigsten Geburtstag, edited by Gerd Althoff, Dieter Geuenich, Otto 
Gerhard Oexle, and Joachim Wollasch, 237-55. Sigmaringen: Jan Thorbecke, 1988.

. "Reformmönchtum und Schriftlichkeit." Frühmittelalterliche Studien 26 (1992): 274-86.

Wright, Roger. Late Latin and Early Romance in Spain and Carolingian France. Liverpool: Frances Cairns, 1982.

Wulstan, David. "Nopi modulaminis melos: The Music of Heloise and Abelard." Plainsong and Medieval Music 11 (2002): 1-23.

Yates, Frances. The Art of Memory. Chicago: University of Chicago Press, 1966.

Ziolkowski, Jan. "Nota Bene: Why the Classics Were Neumed in the Middle Ages." The Journal of Medieval Latin 10 (2000): 74-114.

\begin{abstract}
This article takes the early notation of the Office hymns as the framework for a new investigation of orality and literacy in musical notation. Of all chant genres, hymns remained an oral tradition the longest, and the notation of entire hymn repertories was apparently rare before 1100 . As a repertory of melodies hardly written down before the eleventh century, the hymns offer an opportunity to study the initial recording of an oral tradition at a time when other chant genres were increasingly notated. The variety of approaches to notating both entire hymn repertories and individual hymns in the sources up to the early twelfth century signals the increasing reliance on writing, as well as the dynamic interaction between orality and literacy, that characterizes monastic textual production in the eleventh century. The article places the notation of hymns in the context of their important role in monastic education and proposes an analogy between hymnaries and monastic customaries.
\end{abstract}

